\title{
CARACTERIZAÇÃO DE UM VÍRUS BACILIFORME ISOLADO DE Solanum violaefolium TRANSMITIDO PELO ÁCARO Brevipalpus phoenicis GEIJSKES (ACARI: TENUIPALPIDAE)
}

\author{
PAULO DE TARSO DE OLIVEIRA FERREIRA
}

PIR A C ICABA

Estado de São Paulo - Brasil Junho - 2005 


\title{
CARACTERIZAÇÃO DE UM VÍRUS BACILIFORME ISOLADO DE Solanum violaefolium TRANSMITIDO PELO ÁCARO Brevipalpus phoenicis GEIJSKES (ACARI: TENUIPALPIDAE)
}

\author{
PAULO DE TARSO DE OLIVEIRA FERREIRA \\ Engenheiro Agrônomo
}

Orientador: Prof. Dr. ELLIOT WATANABE KITAJIMA

Tese apresentada à Escola Superior de
Agricultura "Luiz de Queiroz", Universidade de
São Paulo, para obtenção do título de Doutor em
Agronomia, Área de Concentração:
Fitopatologia.

PIRA CICABA

Estado de São Paulo - Brasil

Junho - 2005 
Dados Internacionais de Catalogação na Publicação (CIP) DIVISÃO DE BIBLIOTECA E DOCUMENTAÇÃO - ESALQ/USP

Ferreira, Paulo de Tarso de Oliveira

Caracterização de um vírus baciliforme isolado de Solanum violaefolium transmitido pelo ácaro Brevipalpus phoenicis Geijskes (Acari: Tenuipalpidae) / Paulo de Tarso de Oliveira Ferreira. - - Piracicaba, 2005.

85 p. : il.

Tese (doutorado) - - Escola Superior de Agricultura Luiz de Queiroz, 2005. Bibliografia.

1. Ácaro-vetor-de-doença-em-planta 2. Biologia (Classificação) 3. Biologia molecular 4. Macha anular 5. Solano-violeta 6. Vírus de planta I. Título

CDD 632.8

"Permitida a cópia total ou parcial deste documento, desde que citada a fonte - O autor" 
À minha família, por todo amor que expressam por mim,

Ofereço

A minha mãe, por sua perseverança em criar e cuidar da sua prole.

Dedico 


\section{AGRADECIMENTOS}

A Deus por estar comigo em todos os momentos.

À Escola Superior de Agricultura Luiz de Queiroz (ESALQ-USP) pela formação profissional.

À Coordenadoria de Aperfeiçoamento de Pessoal de Ensino Superior (CAPES) pela concessão da bolsa de estudo.

Ao Prof. Dr. Elliot W. Kitajima pela orientação, e pelo exemplo de dedicação científica e acadêmica.

Aos professores do Setor de Fitopatologia da ESALQ/USP pela troca de experiências e ensinamentos.

Ao Centro APTA Citros "Sylvio Moreira", nas pessoas do Marcos Antônio Machado, Juliana Freitas-Astúa, Eliane Cristina Locali, Renata Antonioli-Luizon e todos os demais que ofereceram apóio logístico e discussão filosófica nos períodos em que lá estive.

Ao meu amigo e irmão Leonardo Sousa Cavalcanti que foi testemunha e compartilhou das minhas alegrias e tristezas durante todos esses anos. 
Aos colegas do curso de pós-graduação em Fitopatologia pelos bons momentos compartilhados.

Aos meus colegas do NAP/MEPA, Renato, Renata Gomes, Renata Faeir, Karen, Berenice e Francisco, pela assistência que me deram no meu trabalho.

Aos meus amigos Alessandro, Simão, Mauro e Dyeme, que fizeram da minha morada um mar de tranqüilidade.

Aos meus amigos Heloísa, Renata, Cristiane, Maria Elisa, Alexandre, Adriana, Maria Paula, Renato, Marília, Cândido Athayde, Kátia, Marissônia e todos os demais amigos que fizeram da minha estada em Piracicaba uma extensão da minha terra natal.

Aos funcionários do Departamento de Fitopatologia, Jefferson, Pedro, Marisa, Sílvia, Fernanda, Rodolfo, Marina e Edivaldo pela consideração de amizade e ajuda durante os anos que ali passei.

Aos companheiros do Tabajara Vila PG Futebol Clube: Luiz Fernando, Alessandro, Simão, Paulo Nazareno, Lucílio, Leonardo Martinelli, Leonardo Cavalcanti, Winter, Jorge, Leo Satoshi, Quelmo, Luciano, Nelson, Julcimar e tantos outros, pela alegria nos momentos de descontração no futebol. 


\section{SUMÁRIO}

RESUMO

Página

viii

2.1 Classificação e biologia de Brevipalpus spp. ..............................................................

2.2 Brevipalpus spp. como vetor de virus de plantas..................................................... 8

2.3 Características dos vírus transmitidos por Brevipalpus spp. ou associados a sua infestação............................................................................................ 13

2.4 Morfologia e citopatologia dos vírus transmitidos por Brevipalpus spp...................... $\quad 19$

2.5 Transmissão mecânica dos vírus transmitidos por Brevipalpus spp......................... 20

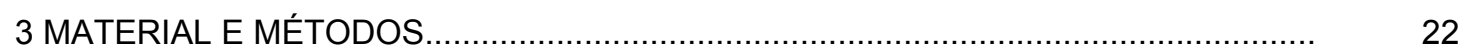

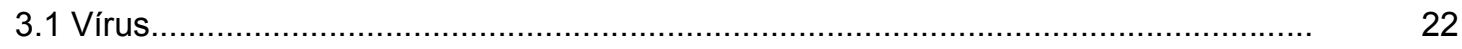

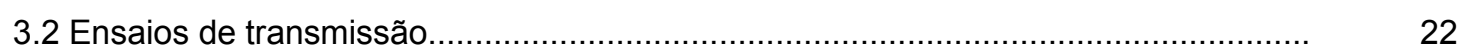

3.2.1 Transmissão mecânica em plantas indicadoras...................................................... 22

3.2.2 Transmissão pelo ácaro Brevipalpus phoenicis................................................ 24

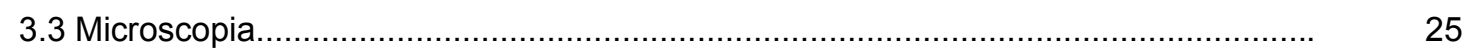

3.3.1 Microscopia eletrônica de varredura (MEV) ……................................................ 25

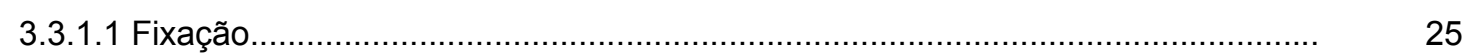

3.3.1.2 Desidratação, secagem ao ponto crítico e metalização...................................... 25

3.3.2 Microscopia eletrônica de transmissão (MET)................................................... 26

3.3.2.1 Fixação e emblocamento............................................................................ 26

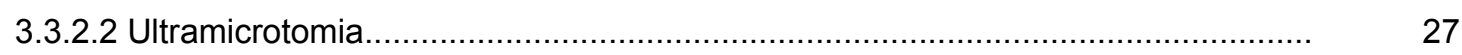

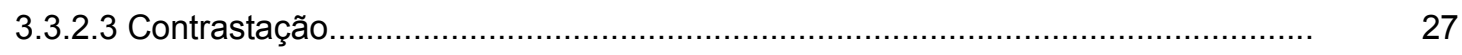

3.3.3 Microscopia de luz................................................................................ 27

3.4 Determinação de propriedades físicas in vitro...................................................... 28

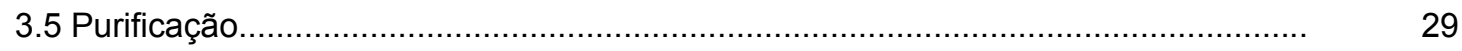

3.5.1 Tentativa de purificação usando protocolo para rhabdovirus................................. 29 
3.5.2 Tentativa de purificação usando protocolo para partícula completa de tospovírus.

3.6 Sequenciamento de fragmentos do genoma viral.......................................... 31

3.6.1 Isolamento de RNA dupla fita (dsRNA) ................................................. 31

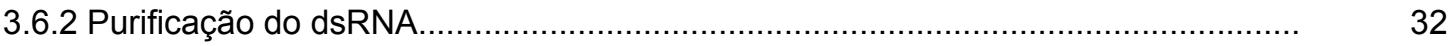

3.6.2.1 Digestão do dsRNA do SvRSV com Mung Bean Nuclease................................. 32

3.6.2.2 Digestão do dsRNA do SvRSV com DNAse I - RNAse free............................ 33

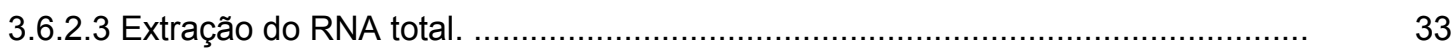

3.6.2.4 Síntese da $1^{\text {a }}$ fita do DNA complementar (cDNA) ..................................... 35

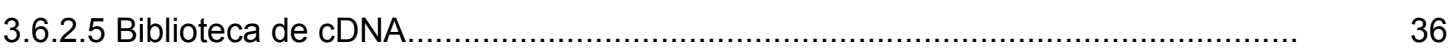

3.6.2.6 Seleção e estoque de clones positivos.................................................... 38

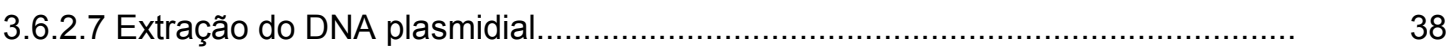

3.6.2.8 Reação de sequenciamento.............................................................. 40

3.6.2.9 Anotação das seqüências das bibliotecas de cDNA contruídas......................... 40

3.6.2.10 Hibridizações............................................................................ 41

3.6.2.11 Pré-hibridização............................................................................ 42

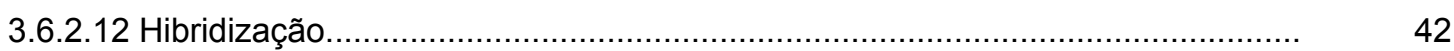

3.6.2.13 Lavagens, Detecção e Revelação......................................................... 43

3.6.3 Síntese de iniciadores (primers) e PCR para detecção.................................... 44

4 RESULTADOS E DISCUSSÃO................................................................. 46

4.1. Ensaios de transmissão........................................................................... 46

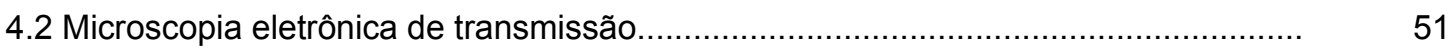

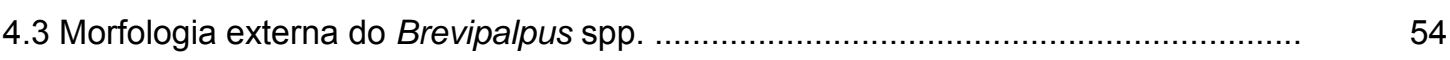

4.4 Determinação de propriedades físicas in vitro............................................. 57

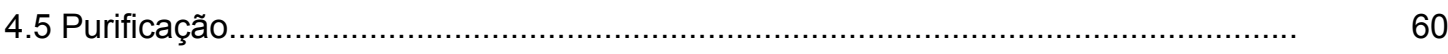

4.6 Sequenciamento de fragmentos do genoma viral............................................. 61

4.6.1 Isolamento de RNA dupla fita (dsRNA) .................................................... 61

4.6.2 Sequenciamento e comparação com outros vírus no GenBank............................. 62

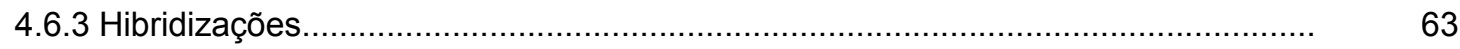

4.6.4 Síntese de iniciadores (primers) e RT-PCR para detecção...................................... 65

$\begin{array}{ll}5 \text { Conclusões } & 69\end{array}$

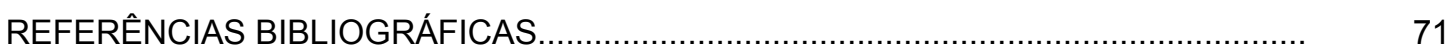




\title{
CARACTERIZAÇÃO DE UM VÍRUS BACILIFORME ISOLADO DE Solanum violaefolium TRANSMITIDOS PELO ÁCARO Brevipalpus phoenicis GEIJSKES (ACARI: TENUIPALPIDAE)
}

\author{
Autor: PAULO DE TARSO DE OLIVEIRA FERREIRA \\ Orientador: Prof. Dr. ELLIOT WATANABE KITAJIMA
}

\section{RESUMO}

Solano-violeta (Solanum violaefolium) é uma ornamental rasteira usada pra cobrir solos de áreas sombreadas. Um vírus que induz manchas anelares nas folhas, tentativamente designado de mancha anular do $S$. violaefoliumm (S. violaefolium ringspot vírus - SvRSV), transmitido pelo ácaro Brevipalpus phoenicis foi encontrado nesta planta em jardins de Piracicaba, SP. Trata-se de um vírus baciliforme que se acumula no lúmen do retículo endoplasmático induzindo viroplasma citoplasmático, assemelhando-se a outros vírus do tipo citoplasmático, dos transmitidos por ácaros Brevipalpus (Acari: Tenuipalpidea). Este trabalho relata algumas de suas propriedades biológicas e a caracterização molecular parcial. SvRSV foi ser transmitido mecanicamente e pelo $B$. phoenicis a várias outras espécies botânicas, sempre causando lesões localizadas. Destas, Datura stramonium mostrou-se a melhor como hospedeira 
experimental. As propriedades físicas do SvRSV in vitro foram: temperatura de inativação - 40-45 ${ }^{\circ} \mathrm{C}$; ponto final de diluição $-10^{-3}-10^{-4}$; longevidade in vitro- 12 dias. Posteriormente, observou-se também infestação destas plantas por $B$. obovatus que em ensaios preliminares transmitiu o SvRSV. Em secções ultrafinas, as partículas do SvRSV mostraram-se ligeiramente mais delgadas que as de outros vírus do tipo citoplasmático, transmitidos por Brevipalpus, e por outro lado formavam eventualmente partículas mais longas, às vezes de ca. $1 \mu \mathrm{m}$. Como os demais vírus, do tipo citoplasmático, transmitido por Brevipalpus, induz a formação de um viroplasma denso e vacuolado no citoplasma. Em casos favoráveis foram observadas fases do processo de morfogênese por "brotação" a partir do material do viroplasma. Dada sua labilidade não foi possível conseguir sua purificação apesar das inúmeras tentativas, usando diferentes protocolos. Logrou-se a extração de dsRNA a partir de $D$. stramonium e a partir dele, obter-se dois fragmentos do genoma viral, identificados como parte da proteína de movimento e da replicase, após seu sequenciamento. Foram produzidos pares de "primer" baseado nestas seqüências que amplificaram especificamente, por RT-PCR, fragmentos de DNA de tamanho esperado, a partir do RNA total extraído de lesões foliares de S. violaefolium e $D$. stramonium infetados. Sondas baseadas nas seqüências obtidas hibridizaram com ss- e dsRNA de lesões de D. stramonium. Ensaios preliminares de RT-PCR e hibridização não resultaram em reação com alguns outros vírus transmitidos por Brevipalpus, do tipo citoplasmático, inclusive o da leprose dos citros (CiLV-C).

Palavras-chave: SvRSV, dsRNA, Brevipalpus, genoma viral, caracterização biológica, propriedades in vitro, CiLV 


\title{
CHARACTERIZATION OF A BACILIFORM VIRUS ISOLATED FROM Solanum violaefolium TRANSMITED BY Brevipalpus phoenicis GEIJSKES (ACARI: TENUIPALPIDAE)
}

\author{
Author: PAULO DE TARSO DE OLIVEIRA FERREIRA \\ Adviser: Prof. Dr. ELLIOT WATANABE KITAJIMA
}

\section{SUMMARY}

Solanum violaefolium is an ornamental Solanaceae, with prostrate, trailing growth cultivated in shaded areas. Plants exhibiting necrotic ringlike spots on the leaves have been found in several gardens and parks at Piracicaba - SP. The ringspot symptoms on the leaves is caused by a vírus, named $S$. violaefolium ringspot virus (SvRSV), and is transmisible by mite Brevipalpus phoenicis (Acari: Tenuipalpidae). Short bacilliform particles are present within the cisternae of endoplasmic reticulum (ER) and often electron dense viroplasm is present in the cytoplasm, characterist of the cytoplasmatic type of Brevipalpus-borne virus. The present study reports some of its biological properties and partial molecular caracterization. SvRSV is easily transmitted to many plant species either by viruliferous $B$. phoenicis or mechanically, always causing local lesions. Datura stramonium was proved to be better as 
experimental host. Its physical properties in vitro were: inactivation thermal point - 40-45 ${ }^{\circ} \mathrm{C}$; final diluition point $-10^{-3}-10^{-4}$; longevity in vitro - 12 days. Afterwards, its was observed that $S$. violaefolium plants were infested by $B$. obovatus that transmitted SvRSV in preliminary assays. Thin sections revealed that SvRSV particles are slightly thinner and sometimes appear very long. In some favorable sections intermediate steps of viral particle morphogenesis by a budding process of the dense material of the viroplasm toward the lumen of ER could be seen. Due to the fragility of the particles, several attempts to purify the virus have failed, despite many protocols tried. It was possible, however, to extract dsRNA from infected tissue of $D$. stramonium, and two segments of viral genome, respectively with homology to movement protein $(\mathrm{mp})$ and replicase (rep) of some known viruses were obtained. Primers were designed based in these sequences, which amplified by RT-PCR, fragments of DNA of expected size from total RNA extracts from leaves lesions of infected S. violaefolium and D. stramonium. Probes based on obtained sequences hibridizated with ss- and dsRNA from lesions of S. violaefolium and D. stramonium. Preliminary assays of RT-PCR and hybridization did not result in positive reaction with other cytoplasmatic type of Brevipalpus-borne viruses, including citrus leprosis (CiLVC).

Keys-words: SvRSV, dsRNA, Brevipalpus, viral genome, biologic characterization, CiLV 


\section{INTRODUÇÃO}

Solanum violaefolium Schott $($ Bitter $)(=$ Lycianthes asarifolia (Kunth \& Bouché) conhecida como solano-violeta ou solano-rasteiro é uma planta ornamental herbácea perene de crescimento rasteiro $(10-15 \mathrm{~cm}$ de altura) pertencente a família das solanáceas. Suas folhas cordiformes são semelhantes às da violeta, daí a origem do nome. É muito utilizada em paisagismo de jardins em parques e praças públicas em áreas sombreadas (Lorenzi \& Souza, 1995, 2001).

Apesar de essas plantas serem de importância ornamental secundária, as mesmas tem sido alvo de estudos, assim como outras ornamentais nas quais foram encontrados vírus transmitidos por Brevipalpus phoenicis Geyskes (Acari: Tenuipalpidae) (mancha anular de Ligustrum, mancha verde da hera, mancha clorótica de Clerodendron thompsonae e de C. $x$ speciosum, mancha verde e manchas cloróticas de Hibiscus rosa sinensis, mancha anular em Malvaviscum, mancha anular de Schefflera, mancha anular em Solanum violaefolium, etc.). Ver tabela 1.

Ácaros Brevipalpus (Tenuipalpidae) estão surgindo como um importante grupo que transmitem vírus de plantas, alguns deles de importância econômica elevada em plantas cultivadas. Apesar disto, a literatura em virologia vegetal tem negligenciado a seu respeito raramente sendo mencionado. Mesmo em livros textos importantes recentes como Plant Virology de Mathews (Hull, 2002) e de interação vírus-planta-vetor (Harris et al., 2001) não há uma citação sequer 
sobre o papel dos ácaros Brevipalpus como vetor e dos vírus por eles transmitidos.

Estudos preliminares mostraram que esses vírus têm semelhanças em sintomatologia, na morfologia e efeitos citopatológicos, além de ter o mesmo ácaro vetor, com enfermidades importantes como leprose dos citros, mancha anular do cafeeiro e pinta verde do maracujazeiro. As exatas relações entre os vários vírus transmitidos por Brevipalpus ainda não estão esclarecidas e é possível que algumas delas tenham papel importante na cadeia epidemiológica daquelas de interesse econômico.

A leprose dos citros originalmente descrito nos EUA (Fawcett, 1936) se destaca, dentre as viroses transmitidas pelos ácaros Brevipalpus, como a mais importante entre as citadas constituindo-se em um dos principais problemas da citricultura paulista, ocorrendo também em vários outros estados da União (Rodrigues et al., 2003). Seus prejuízos diretos têm sido avaliados entre 40 a 60 milhões de dólares/ano (Salva \& Massari, 1995). O uso de defensivos químicos tem sido bastante expressivo, principalmente para o controle do ácaro da leprose e do ácaro da falsa ferrugem (Phyllocoptruta oleivora Ashmead). Anualmente, são gastos aproximadamente US\$ 90 milhões de dólares, sendo que mais de $80 \%$ desse valor são destinados ao combate do ácaro da leprose (Neves et al., 2001; Salvo Filho, 1997) e o restante, para combater P. oleivora. Em 2003, gastou-se cerca de US\$ 70 milhões com acaricidas na citricultura brasileira, representando mais de $50 \%$ dos custos com todas as classes de defensivos agrícolas utilizados em citros (Neves et al., 2003).

Dada sua importância econômica, a leprose dos citros é a que tem sido mais investigada. Há numerosas informações já disponíveis sobre a etiologia, relações com o vetor, avaliação de incidência e perdas, controle químico e biológico, etc. (Guirado \& Silvério, 1992; Oliveira \& Donadio, 1995, Rodrigues et al., 2003).

Como existem ainda problemas em se ter uma hospedeira adequada para a multiplicação e dificuldades em se purificar, houve dificuldades em 
avançar nos estudos sobre as propriedades básicas do vírus da leprose dos citros. Apesar disto, avanços foram feitos nos conhecimentos sobre o vírus da leprose dos citros. Sabe-se, por exemplo, que há dois tipos distintos, ambos transmitidos pelo ácaro Brevipalpus: o tipo citoplasmático (CiLV-C), prevalente e o tipo nuclear (CiLV-N), de rara ocorrência. Parte do genoma do CiLV-C, pode ser seqüenciado, através da extração de dsRNA e que permitiu estabelecer métodos moleculares para a detecção do CiLV-C (Locali et al., 2003c). Uma extensão desta linha de investigação permitiram a pesquisadores da empresa de biotecnologia Alellyx completar a seqüência do genoma do CiLV-C (R. Pascon, comunicação pessoal). Uma estratégia alternativa é o estudo de vírus similares a ele, em especial seus aspectos moleculares e organização genômica. Seria viável, p.ex., produzir "primers" para se amplificar partes do genoma ou anticorpos que reconheçam proteínas do vírus da leprose a partir destes outros vírus. Isto proveria de importantes ferramentas para detecção do vírus da leprose em diferentes hospedeiras, mesmo assintomáticas ou no próprio vetor fornecendo dados cruciais para se equacionar sua epidemiologia. Também informações sobre seu genoma abririam caminhos para compreender suas interações com genes das hospedeiras e os mecanismos de resistência e a possível exploração de plantas transgênicas resistentes, expressando genes virais. Dentre os vírus transmitidos por Brevipalpus o que causa mancha anular em Solanum violaefolium (tentativamente designado de Solanum violaefolium ringspot vírus - SVRSV) se apresentou como promissor, pois foi transmitido com facilidade, tanto pelo ácaro Brevipalpus como mecanicamente, para várias plantas teste em ensaios preliminares, e ocorre em concentrações elevadas nos tecidos (Kitajima \& Moraes, 2000; Kitajima et al., 2001a).

Este trabalho tem como objetivo, caracterizar biológica e molecularmente o vírus de mancha anular de Solanum violaefolium (SVRSV) descoberto em Piracicaba, SP (Kitajima \& Moraes, 2000). Este vírus pertence ao grupo dos que são transmitidos pelo ácaro Brevipalpus sp. com efeitos citopáticos do tipo citoplasmático, basicamente similar ao observado na maioria 
dos isolados do vírus da leprose dos citros. Pretende-se estudar detalhes da transmissão mecânica e pelo ácaro B. phoenicis, gama de hospedeiras suscetíveis, escolha de uma hospedeira para multiplicação dos vírus, detecção de dsRNA, seqüenciamento do genoma viral e sua comparação com demais vírus, produção de sondas e "primers" para detecção molecular. Sondas e "primers" produzidos a partir destes vírus serão testados contra outros vírus similares, em especial, o da leprose dos citros. Serão avaliados em maior detalhes a morfologia das partículas virais e seus efeitos citopáticos na planta infetada. Também serão estudados detalhes morfológicos do ácaro vetor. 


\section{REVISÃO DE LITERATURA}

2.1 Classificação e biologia de Brevipalpus spp.

A família Tenuipalpidae Berlese inclui mais de 600 espécies em 30 gêneros (Smiley \& Gerson, 1996; Smiley et al., 1996) e juntamente com as famílias Tetranychidae, Tuckerellidae e Linotetranidae, é agrupada na superfamília Tetranychoidea, sub-ordem Prostigmata, classe Arachnida e subclasse Acari. Dentro da família Tenuipalpidae, o gênero Brevipalpus Donnadeiu, 1875 é o maior, com aproximadamente 300 espécies. Esse gênero tem sido separado em grupos de acordo com o número de setas marginais no histerossoma. B. californicus (Banks) possui seis pares de setas, grupo esse que contém 46 espécies. $O$ outro grupo apresenta apenas cinco pares de setas marginais no histerossoma e contém nove espécies, incluindo $B$. phoenicis (Geijskes) e B. obovatus Donnadieu (Gonzáles, 1975). A divisão destes grupos também pode ser feita através do número de setas sensoriais (solenídios) na parte distal do tarso do segundo par de pernas (Jeppson et al., 1975). Segundo Gonzáles (1975) e Oomen (1982) apenas B. phoenicis possui a combinação de cinco pares de setas histerossomais marginais e 2 solenídios.

A família Tenuipalpidae ocorre em diversas espécies hospedeira (Childers et al., 2003). As três principais espécies de Brevipalpus foram relatadas em 928 espécies de plantas em 513 gêneros distribuídas em 139 famílias (Childers et al., 2003). As hospedeiras consistem de monocotiledôneas, dicotiledôneas, plantas anuais, perenes, plantas ornamentais, entre outras. Foram 316 espécies de plantas hospedeiras identificadas para B. californicus, 
451 espécies de plantas hospedeiras de $B$. obovatus, e 486 espécies de plantas hospedeiras de B. phoenicis (Childers et al., 2003). O Brevipalpus spp é uma espécie polífaga e apresenta distribuição cosmopolita, tendo sido encontrado na África, Ásia, Austrália, Europa, América do Norte, América do Sul e Ilhas do Pacífico (Haramoto, 1969). No Brasil, a presença deste ácaro em citros foi confirmada em 1959 (Rossetti \& Salibe, 1959). Segundo Trindade \& Chiavegato (1994) o ácaro da leprose foi encontrado em 34 espécies de plantas cultivadas, ornamentais e plantas daninhas em pomares cítricos de várias localidades do Estado de São Paulo. Segundo Chiavegato \& Mischian (1987), este gênero tem sido relacionados a mais de 80 gêneros de plantas hospedeiras, sendo citros o principal hospedeiro. É considerada uma importante praga para as culturas de chá, café, algodão, e frutíferas decíduas tropicais.

B. phoenicis (Geijskes, 1939), também denominado de ácaro plano ou ácaro da leprose dos citrus, teve suas espécimes originais coletadas em Phoenix sp. em casas-de-vegetação na Holanda em 1939 (Gonzales, 1975). Haramoto (1969) constatou que o maior número de relatos desse ácaro ocorre em áreas próximas dos trópicos, onde as condições climáticas e a abundância de hospedeiros favorecem a sua ocorrência (Gonzáles, 1975).

O ciclo biológico do ácaro da leprose é constituído pelas fases de ovo, larva, protoninfa, deutoninfa e adulto, sendo que entre cada instar ocorrem períodos de imobilidade chamados de protocrisálida, deutocrisálida e teliocrisálida (Haramoto, 1969; Flechtmann, 1977). A postura é realizada em locais protegidos, como em frestas na superfície de plantas. Os ovos são colocados individualmente, contudo, ovos agrupados são observados com freqüência (Haramoto, 1969; Lal, 1978).

O ácaro Brevipalpus se reproduz principalmente por partenogênese telítoca, isto é, fêmeas não fecundadas dão origem a fêmeas idênticas a progenitora (Helle et al., 1980), existindo também a reprodução sexuada, quando machos estão presentes na população (cerca de 1\%). Estudos conduzidos por Weeks et al. (2001) mostraram que B. phoenicis encontra-se na 
natureza exclusivamente na forma haplóide, isto é, possuem dois cromossomos que são geneticamente distintos, não havendo cromossomos homólogos, e que essa anomalia é causada pela infecção por uma bactéria endosimbiótica que resulta na feminilização dos machos.

A densidade populacional de $B$. phoenicis nos pomares de citros do Estado de São Paulo começa a aumentar a partir dos meses de março-abril, que corresponde ao período de diminuição das precipitações, e o pico populacional ocorre no período de setembro-outubro, diminuindo com o aumento das precipitações (novembro-dezembro) (Oliveira, 1986).

Diversos pesquisadores estudaram a biologia de $B$. phoenicis (Haramoto, 1969; Lal, 1978; Chagas et al., 1984; Chiavegato, 1986; Trindade, 1990; Trindade \& Chiavegato, 1994 e Alves, 1999). Temperatura e o tipo de hospedeiro são os principais fatores que afetam o desenvolvimento desse ácaro. Chiavegato (1986) estudando a biologia sobre frutos e folhas de laranja, observou que o desenvolvimento do ácaro foi mais rápido em frutos, quando comparados com o desenvolvimento em folhas. Chiavegato (1986) também observou que, com o aumento da temperatura, ocorreu um desenvolvimento mais rápido do ácaro e o número de ovos aumentou significativamente. $\mathrm{O}$ desenvolvimento de ovo a adulto foi de 19,20 dias a temperatura de $25^{\circ} \mathrm{C}$, sendo que as maiores taxas de viabilidades da fase larval (caracterizada como fase crítica) foram observadas também a essa temperatura. Períodos maiores foram observados à temperatura de $20^{\circ} \mathrm{C}$ cujo valor médio foi de 43,47 dias. $\mathrm{O}$ número de ovos em frutos à 30 e $20{ }^{\circ} \mathrm{C}$ foi de 39,17 e 8,57 ovos, respectivamente, enquanto em folhas à $30^{\circ} \mathrm{C}$ foi de 8,57 ovos.

Um fator importante nas preferências de substrato pelo ácaro da leprose é a verrugose dos citros, que é uma doença causada pelo fungo Elsinoe fawcetti Bitancourt \& Jenkins, que forma uma placa rugosa na superfície do fruto (Knorr \& Denmark, 1970; Nakano et al., 1987; Albuquerque et al., 1995; Barreto \& Pavan, 1995). O ácaro, quando criado em frutos com verrugose, apresentou maior número de sobreviventes, maior número de ovos e menor 
número de ácaros mortos naturalmente e na barreira de cola, quando comparados com frutos sadios (Nakano et al., 1987).

\subsection{Brevipalpus spp. como vetor de vírus de plantas}

Os primeiros relatos de ácaros do gênero Brevipalpus, atuarem como vetores de viroses de plantas foram feitos por Frezzi (1940) e Vergani (1945) na Argentina, transmitindo a "lepra explosiva" de laranjeiras com B. obovatus. Vergani (1942), citado por Kitajima et al. (2003), também demonstrou que este ácaro serve como vetor da mancha anular do ligustro (Ligustrum lucidum Aiton) (Ligustrum ringspot virus - LiRSV), que entre nós é transmitido por B. phoenicis (Rodrigues \& Nogueira, 1997). No Brasil, demonstrou-se que B. phoenicis transmite a leprose (Musumecci \& Rossetti, 1963) e a clorose zonada (Rossetti et al., 1965). Knorr (1968), obteve evidências que a leprose na Florida, EUA, era transmitido pelo $B$. californicus e $B$. obovatus. A transmissão da mancha anular do cafeeiro (Coffea arabica L.)(Bitancourt, 1938), em São Paulo, com o ácaro B. phoenicis foi demonstrada por Chagas (1978a). Em 1997, comprovouse que uma doença, designada de pinta verde do maracujazeiro (Passiflora edulis Sims f. flavicarpa Deg) (passionfruit green spot virus - PGSV), que estava dizimando culturas na região de Vera Cruz, SP, era de natureza viral e transmitida pelo B. phoenicis (Kitajima et al., 1997). Hoje já se tem relato desta doença no estado de Minas Gerais, Bahia e Maranhão (Takatsu et al., 2000; Chagas et al., 2000; Morais et al., 2004). Maeda et al. (1998) no Japão provou que Orchid fleck virus-OFV era transmitido por $B$. californicus. Até fins da década dos 1990, apenas quatro vírus transmitidos por Brevipalpus eram conhecidos (OFV, CiLV, PGSV e LiRSV). Desde então houve um contínuo crescimento de casos de enfermidades de plantas, caracterizadas por lesões localizadas (mancha anular/ clorótica em folhas verdes ou manchas verdes em folhas senescentes), na maioria em ornamentais transmitidos por ácaros 
Brevipalpus ou associadas à sua infestação. Contudo, as relações precisas entre elas não são conhecidas podendo representar casos de alguns poucos vírus infetando numerosas hospedeiras. A tabela 1 apresenta um resumo dos casos conhecidos até hoje. A grande maioria destas enfermidades foi constatada no Brasil, embora também ocorram em outros países do continente americano como Argentina, Paraguai, Bolívia, Venezuela, Panamá, Costa Rica, Guatemala, Honduras, Estados Unidos e mesmo no Caribe, como em Cuba. Excetua-se o OFV, de distribuição mundial, certamente devido ao intenso comércio mundial e aos colecionadores que transitam plantas infetadas. Fora do continente, conhece-se apenas o caso da mancha clorótica da violeta (Violet ringspot virus) descrito na Austrália, embora não se saiba se está associada à infestação por Brevipalpus (Gowanlock \& Ditzegen, 1995). Em recentes viagens à África do Sul e Australia, Kitajima e Rodrigues não puderam constatar casos de vírus transmitidos por Brevipalpus (E.W. Kitajima \& J.C.V. Rodrigues, comunicação pessoal). O caso da clorose zonada merece um comentário: é uma doença de ocorrência rara, aparentemente restrita à zona litorânea dos Estados de São Paulo e Rio de Janeiro (embora recentemente teria sido constatado em Sergipe [A. J. Boari, comunicação pessoal]) caracterizado por sintomas de manchas anelares/elipticas alternando áreas cloróticas e verdes de tamanho variado, nas folhas e frutos (Bitancourt \& Grillo, 1934). Foi demonstrada sua transmissão por B. phoenicis (Rossetti et al., 1965). Contudo não se conseguiu detectar partículas presumivelmente virais nos tecidos das lesões (C.M. Chagas e E.W. Kitajima, comunicação pessoal). No Brasil, B. phoenicis tem sido o ácaro mais encontrado transmitindo os vírus ou associados à sua presença, nas lesões (Tabela 1). A exceção é o caso da mancha anular da dama-da-noite (Cestrum nocturnum $\mathrm{L}$ ) que seria transmitido por B. obovatus (Freitas-Astúa et al., 2002; 2004). O OFV no Brasil deve, provavelmente, ser transmitido por $B$. californicus, que tem sido encontrado em orquídeas com lesões (G.J. Moraes, comunicação pessoal), mas não houve ainda ensaios que comprovassem o fato. 
Tabela 1. Lista dos casos conhecidos de vírus ou presumíveis vírus transmitidos por ácaros Brevipalpus (Acari: Tenuipalpidae) ou associados à sua infestação, causando sintomas localizados em diferentes espécies de plantas, e sua distribuição geográfica

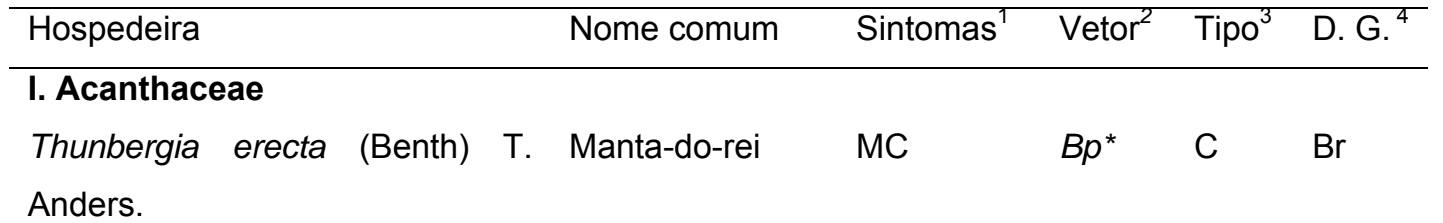

II. Apiaceae

Hydrocotyle

leucochephala Acariçoba

MC

$B p^{*} \quad \mathrm{~N} \quad \mathrm{Br}$

Cham. \& Schlet.

III. Apocinaceae

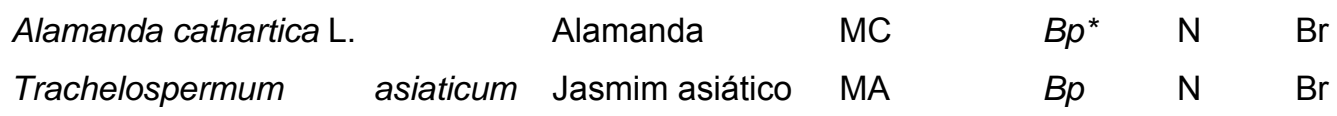

Áurea

IV. Anonnaceae

Annona muricata L.

Graviola

MA

$B p^{*} \quad \mathrm{~N} \quad \mathrm{Br}$

V. Araceae

Anthurius sp.

Spatiphyllum wallisi Regel.

Antúrio $\quad \mathrm{MC}$

$B p^{\star} \quad \mathrm{C} \quad \mathrm{Br}$

Spatiphyllum wallisi Regel.

Lírio-da-paz MV

$B p^{*} \quad C \quad B r$

Monstera deliciosa Liebmann

Lírio-da-paz MC

$\mathrm{Bp} \quad \mathrm{N} \quad \mathrm{Br}$, Bo

VI. Araliaceae

Hedera canariensis L.

Costela-de-adão MA

$B p^{*} \quad \mathrm{~N} \quad \mathrm{Br}$

Hedera canariensis L.

Hera

MV

Bp $\quad$ C $\quad B r$

Schefflera actinophylla

Hera

MA

$B p \quad \mathrm{~N} \quad \mathrm{Br}$

Hams

(End.)

Árvore-guarda-

MA

$B p$

C

$\mathrm{Br}$

\section{Asteraceae}

Bidens sp

Picão

MC

$B p^{*} \quad \mathrm{~N} \quad \mathrm{Br}$

VIII. Geraniaceae

Pelargonium hortorum

L.H. Gerânio

MV

$B p^{*}$

C $\mathrm{Br}$

Bailey

Pelargonium hortorum

L.H. Gerânio

MC

$B p^{\star} \quad \mathrm{N} \quad \mathrm{Br}$

Bailey. 
Tabela 1. Lista dos casos conhecidos de vírus ou presumíveis vírus transmitidos por ácaros Brevipalpus (Acari: Tenuipalpidae) ou associados à sua infestação, causando sintomas localizados em diferentes espécies de plantas, e sua distribuição geográfica

\begin{tabular}{|c|c|c|c|c|c|}
\hline Hospedeira & Nome comum & Sintomas $^{1}$ & Vetor $^{2}$ & Tipo $^{3}$ & D. G. ${ }^{4}$ \\
\hline \multicolumn{6}{|l|}{ IX. Labiatae } \\
\hline Salvia leucantha Cav. & Sálvia-branca & MV & $B p$ & C & $\mathrm{Br}$ \\
\hline Salvia leucantha Cav. & Sálvia-branca & MC & $B p$ & $\mathrm{~N}$ & $\mathrm{Br}$ \\
\hline \multicolumn{6}{|l|}{ X. Liliaceae } \\
\hline Dracaena marginata Hort. & Dracena-de- & MA & $B p^{*}$ & $\mathrm{C}$ & $\mathrm{Br}$ \\
\hline & Madagascar & & & & \\
\hline Cordyline terminalis (L.) Kunth & $\begin{array}{l}\text { Dracena- } \\
\text { vermelha }\end{array}$ & MC & $B p^{*}$ & C & $\mathrm{Br}$ \\
\hline \multicolumn{6}{|l|}{ XI. Malvaceae } \\
\hline Hibiscus cannabinus L. & Kenaf & MV & $B p$ & $\mathrm{C}$ & $\mathrm{Br}$ \\
\hline Hibiscus cannabinus L. & Kenaf & MC & $B p$ & $\mathrm{~N}$ & $\mathrm{Br}$ \\
\hline Hibiscus coccineus Kemper & scarlet hibiscus & MC & $B p^{*}$ & $\mathrm{~N}$ & $\mathrm{Br}$ \\
\hline Hibiscus rosa-sinensis L. & Hibisco & MV & $B p$ & $\mathrm{C}$ & $\begin{array}{l}\mathrm{Br}, \mathrm{Bo}, \\
\mathrm{Cu}\end{array}$ \\
\hline Hibiscus rosa-sinensis L. & Hibisco & MC & $B p$ & $\mathrm{~N}$ & $\mathrm{Br}, \mathrm{Bo}$ \\
\hline Hibiscus schizopetalus Hook. $f$ & Hibisco-crespo & MV & $B p$ & $\mathrm{C}$ & $\mathrm{Br}$ \\
\hline Hibiscus schizopetalus Hook. $\mathrm{f}$ & Hibisco-crespo & MC & $B p$ & $\mathrm{~N}$ & $\mathrm{Br}$ \\
\hline Hibiscus syriacus L. & Hibisco-da-Síria & MV & $B p$ & $\mathrm{C}$ & $\mathrm{Br}$ \\
\hline Malvaviscus arboreus & Malvavisucs & MA & $B p^{\star}$ & $\mathrm{N}$ & $\mathrm{Br}$ \\
\hline \multicolumn{6}{|l|}{ XII. Myrtaceae } \\
\hline \multicolumn{6}{|l|}{ XIII. Oleaceae } \\
\hline Ligustrum spp. & Ligustro & MC/MV & $\begin{array}{l}\text { Bp, } \\
\text { Bo }\end{array}$ & C & $\mathrm{Br}, \mathrm{Ar}$ \\
\hline \multicolumn{6}{|l|}{ XV. Passifloraceae } \\
\hline $\begin{array}{l}\text { Passiflora edulis Sims } f \text {. } \\
\text { flavicarpa Deg. }\end{array}$ & Maracujá & MV & $B p$ & $\mathrm{C}$ & $\mathrm{Br}$ \\
\hline Passiflora alata Dryand & Maracujá-doce & MV & nd & $\mathrm{C}$ & $\mathrm{Br}$ \\
\hline
\end{tabular}


Tabela 1. Lista dos casos conhecidos de vírus ou presumíveis vírus transmitidos por ácaros Brevipalpus (Acari: Tenuipalpidae) ou associados à sua infestação, causando sintomas localizados em diferentes espécies de plantas, e sua distribuição geográfica

\begin{tabular}{|c|c|c|c|c|c|}
\hline Hospedeira & Nome comum & Sintomas $^{1}$ & Vetor $^{2}$ & Tipo $^{3}$ & D. G. ${ }^{4}$ \\
\hline \multicolumn{6}{|l|}{ XIV. Orchidaceae } \\
\hline Angraecum, Aspasia, Arundina, & Orquídea & $\mathrm{MC} / \mathrm{MA}$ & $B c$ & $\mathrm{~N}$ & Mund. \\
\hline Baptistonia, Bifenaria, Brassia, & & & & & \\
\hline Bulbophyllum, $\quad$ Cattleya, & & & & & \\
\hline Coelogyne, & & & & & \\
\hline Dendrobium, & & & & & \\
\hline Dockrillia, Encyclia, Hormidium, & & & & & \\
\hline Liparis, Miltonia, Odontoglossum, & & & & & \\
\hline Oncidium, Pahius, Pescatorea, & & & & & \\
\hline Phalaenopsis, $\quad$ Polstachza, & & & & & \\
\hline Renanthera, Satanhopea, Stenia, & & & & & \\
\hline Trigonidium, Vanda, Zigopetalum & & & & & \\
\hline Coelogyne, Phaius, Xylobium & Orquídea & MA & nd & C & $\mathrm{Br}$ \\
\hline \multicolumn{6}{|l|}{ XVI. Piperaceae } \\
\hline Piper callosum Ruiz \& Pav. & Guayusa & MC & $B p^{*}$ & $\mathrm{~N}$ & $\mathrm{Br}$ \\
\hline Piper nigrum L. & $\begin{array}{l}\text { Pimenta-do- } \\
\text { reino }\end{array}$ & MC & $B p^{\star}$ & $\mathrm{N}$ & $\mathrm{Br}$ \\
\hline \multicolumn{6}{|l|}{ XVII. Pittosporaceae } \\
\hline Pittosporum tobira (Thunb.) Ait. & $\begin{array}{l}\text { Pitósporo } \\
\text { japonês }\end{array}$ & MA & $B p^{*}$ & $\mathrm{~N}$ & EUA \\
\hline \multicolumn{6}{|l|}{ XVIII. Plumbaginaceae } \\
\hline $\begin{array}{l}\text { Plumbago auriculata Lam. } \\
\text { XIX. Rubiaceae }\end{array}$ & XIX. Rubiaceae & MC & $B p^{*}$ & C & $\mathrm{Br}$ \\
\hline Coffea arabica L. & Café & MA & $B p$ & $\mathrm{~N}$ & $\mathrm{Br}$ \\
\hline $\begin{array}{l}\text { Mussaenda erytrophylla Schum. } \\
\text { \& Thonn. }\end{array}$ & Mussaenda & MC & $B p^{*}$ & $\mathrm{~N}$ & $\mathrm{Br}$ \\
\hline \multicolumn{6}{|l|}{ XX. Rutaceae } \\
\hline Citrus sinensis Osbeck & Laranja-doce & MC/MA & $\mathrm{T}$ & C & $\mathrm{Am}$ \\
\hline Citrus sinensis Osbeck & Laranja-doce & $\mathrm{MC}$ & $B p$ & $\mathrm{~N}$ & $\mathrm{Br}, \mathrm{Pa}$ \\
\hline Citrus reticulata Blanco & Tangerina & $\mathrm{MC} / \mathrm{MA}$ & $B p$ & C & $\mathrm{Br}$ \\
\hline
\end{tabular}


Tabela 1. Lista dos casos conhecidos de vírus ou presumíveis vírus transmitidos por ácaros Brevipalpus (Acari: Tenuipalpidae) ou associados à sua infestação, causando sintomas localizados em diferentes espécies de plantas, e sua distribuição geográfica

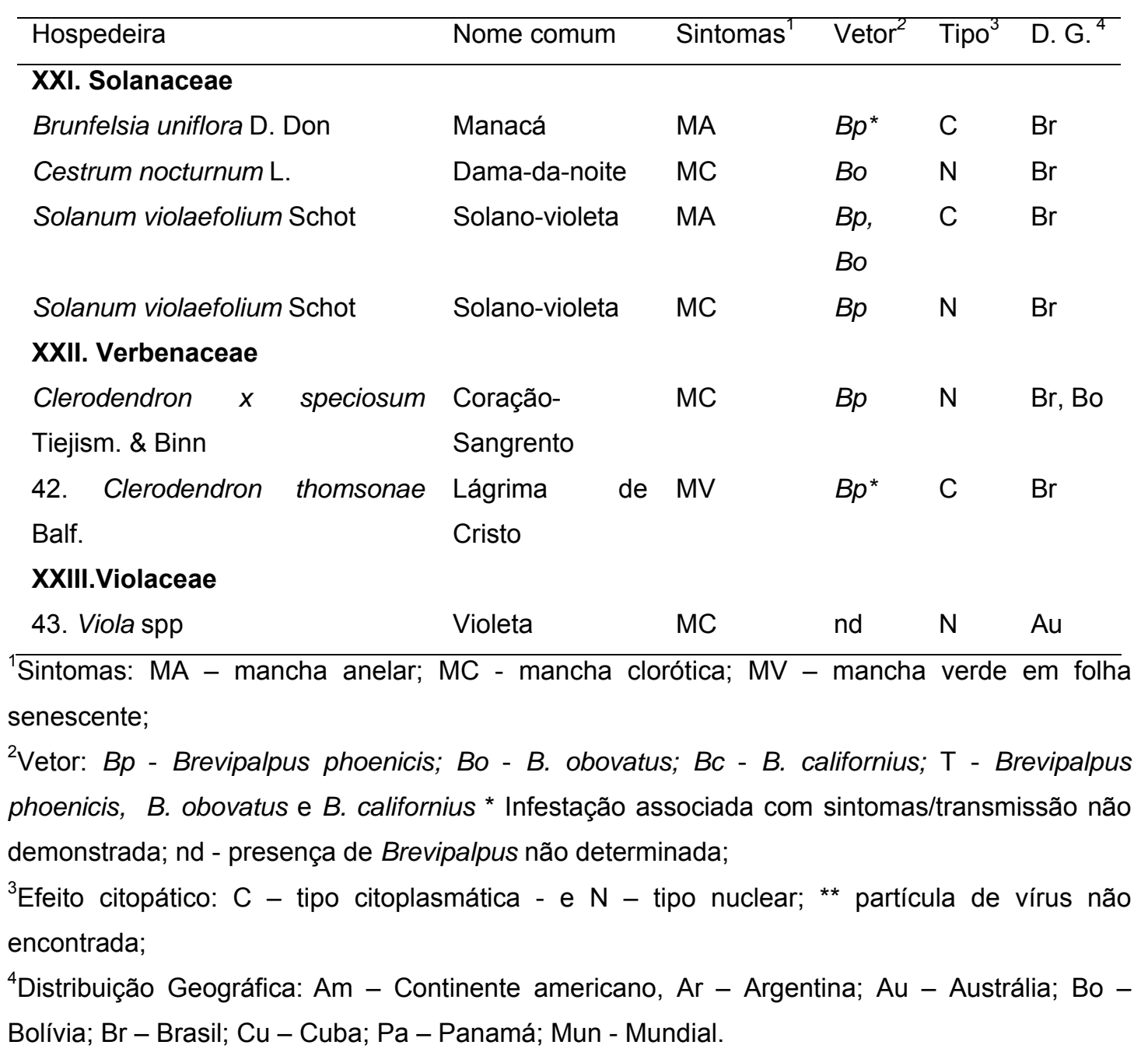

2.3 Características dos vírus transmitidos por Brevipalpus spp. ou associados a sua infestação

Sintomatologia causada pelos vírus transmitidos por Brevipalpus é do tipo localizado em folhas, ramos e frutos tanto em infecções naturais como em 
infecções experimentais, o que de início sugeriam que as lesões eram resultantes de toxinas dos ácaros (Knorr, 1968). A microscopia eletrônica ofereceu uma das melhores evidências de que essas lesões localizadas teriam etiologia viral (Kitajima et al., 1972; Doi et al., 1977; Colaríccio et al., 1995). A figura 1 mostra os sintomas típicos que aparecem em citros. Em S. violaefolium o sintoma se caracteriza por lesões cloróticas, anelares circulares que pode progredir para uma necrose (Figura 2).

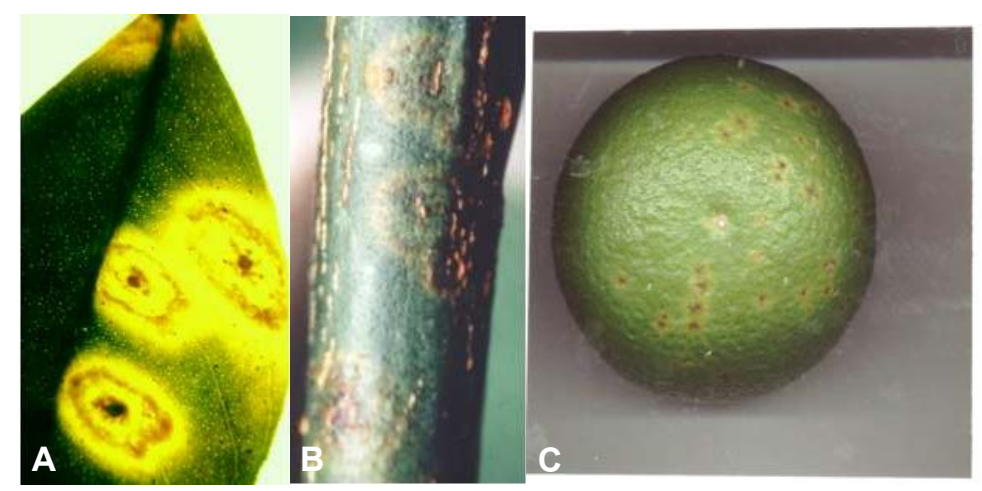

Figura 1 - Sintoma de lesões cloróticas em Citrus sp. A - folha; B - ramo; C - fruto

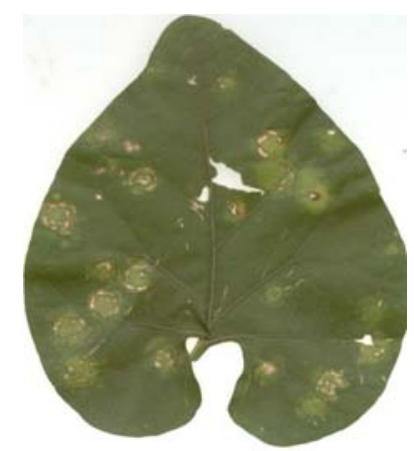

Figura 2 - Sintoma de mancha anelar em Solanum violaefolium

Há dois padrões citopáticos induzidos pelos vírus transmitidos por Brevipalpus. O padrão nuclear geralmente está associado à membrana do envolucro nuclear ou do retículo endoplasmático e apresenta um viroplasma elétron transparente. $\mathrm{O}$ padrão citoplasmático possui membrana, se encontra 
no lúmem do retículo endoplasmático e apresenta um viroplasma elétron denso no citoplasma (Kitajima et al., 2003) (Figura 3A).

$\mathrm{O}$ vírus da mancha anelar da orquídea (Orchid fleck virus - OFV), transmitido por $B$. californicus, é considerado do tipo nuclear, pois foram observadas inclusões nucleares do tipo viroplasmas, bem como vesículas contendo material fibrilar (Doi et al., 1977).

Kitajima et al. (1972) descreveram partículas do tipo baciliformes, medindo $100-110 \mathrm{~nm}$ de comprimento e $40-50 \mathrm{~nm}$ de largura, associadas com viroplasmas no núcleo em células de tecidos infectados com leprose. Kitajima \& Costa (1972) e Chagas (1980) observou partículas semelhantes em tecido de café com sintomas de mancha anelar (CoRSV)

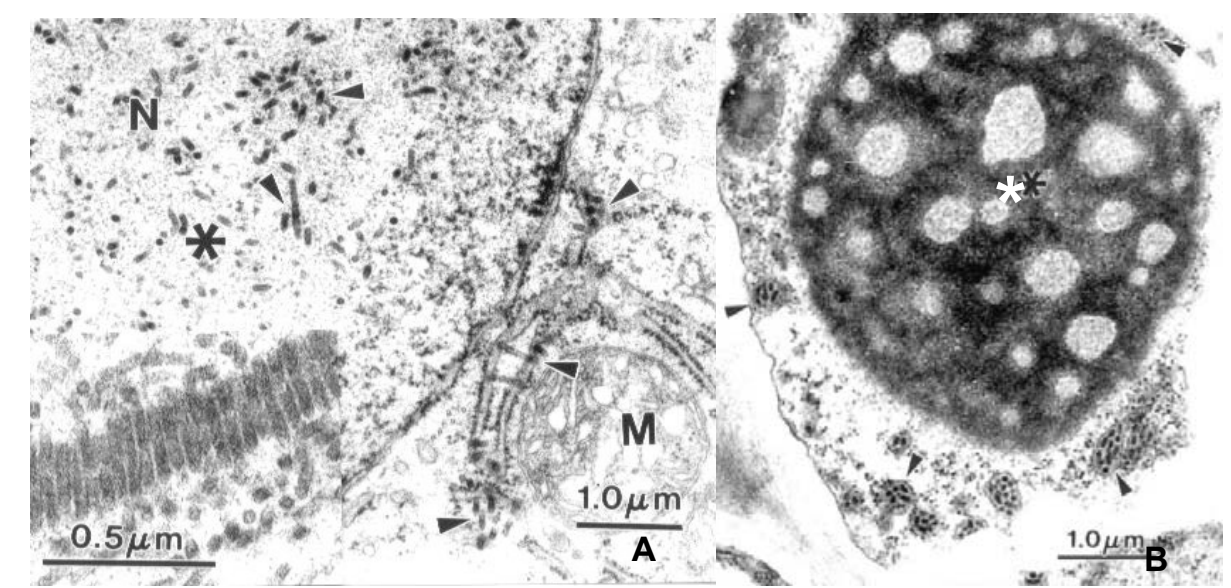

Figura 3 - Fotografia de cortes ultrafinos de tecidos de citrus observado ao microscópio eletrônico de transmissão (A) Partículas agrupadas mostrando efeito citopático tipo nuclear em citrus $\mathrm{N}$ - núcleo, * viroplasma elétron transparente, $M$ - mitocôndrias. (B) Viroplasma elétron-denso no citoplasma, ${ }^{*}$ viroplasma eletron-denso. As setas pretas indicam as partículas virais

Kitajima et al. (1974b) e Colaríccio et al. (1995) encontraram partículas baciliformes associadas ao lúmem do retículo endoplasmático, no citoplasma de 
células do parênquima e também pequenas vesículas contendo material fibriliar (Figura 3B). Na província de Chiriqui no Panamá foram detectados dois tipos de partículas em material de campo (Dominguez et al., 2000). Estes fatos indicam a existência de duas formas distintas de vírus da leprose (nuclear e citoplasmática) transmitida pelo Brevipalpus (Rodrigues et al., 2003).

É importante mencionar que em algumas hospedeiras, pode-se encontrar o tipo nuclear e/ou citoplasmático, como tem sido constatado com a leprose dos citros (Kitajima et al., 1972; Colariccio et al., 1995; Dominguez et al., 2000), em orquídeas (Doi et al, 1977; Freitas-Astúa et al., 1999), Hibiscus (Kitajima et al., 1999; Kitajima \& Rodrigues, 2001); Clerodendron (Kitajima \& Moraes, 2000) e Solanum violaefolium (Kitajima \& Moraes, 2000, Kitajima et al., 2004). Eventualmente, os dois tipos podem ocorrer numa mesma célula, como observado por Kitajima (Kitajima et al., 2003).

Alguns desses vírus mencionado anteriormente foram, com sucesso, transmitidos mecanicamente, como OFV, CoRSV e recentemente o vírus da mancha clorótica de Clerodendron (CICSV). Estes três vírus têm uma citopatologia com padrão nuclear. No caso da mancha anular do cafeeiro, temse obtido avanços significativos. Em condição de campo e casa-de-vegetação com temperaturas em torno de 20 a $27^{\circ} \mathrm{C}$, esses vírus tem se caracterizado por não apresentar infecção sistêmica nas plantas hospedeiras, bem como nas plantas indicadoras. Entretanto, Boari et al. (2003) observaram que, se mantidas por cerca de duas semanas à temperaturas em torno de 29 a $32^{\circ} \mathrm{C}$, plantas de C. quinoa inoculadas com o CoRSV apresentam clareamento de nervuras em folhas não inoculadas, demonstrando que esse vírus tem a capacidade de infectar a planta sistemicamente. Isto tem sido observado para o OFV e também para o CICSV (Kitajima et al., dados não publicados). Já se obteve sucesso na transmissão mecânica da leprose tipo citoplasmática para citrus e outras espécies (Colariccio et al., 1995). Entretanto ainda não há relatos deste vírus se difundir sistemicamente pela planta. 
Tanto o OFV (Kondo et al., 1998), quanto o CoRSV (Boari et al., 2004) já foram purificados. Isto permitiu a produção de anticorpo para detecção e diagnose. Boari et al. (2004) fizeram estudos de relacionamento serológico e constataram que estes dois vírus apresentam uma fraca reação cruzada.

Vírus de ssRNA (RNA fita simples) representa cerca de $90 \%$ dos que infectam plantas. Durante sua replicação nas células das plantas, esses vírus, produzem um produto molecular intermediário - dsRNA que é a forma replicativa e está presente de forma consistente quando a planta está infectada (Pecci, 1999). O dsRNA pode ser relacionado à forma replicativa dos vírus de ssRNA, pode ser a constituição genômica de alguns vírus como os reovírus e vírus crípticos. dsRNA pode ainda ter origem endógena em alguns genótipos de algumas espécies de plantas (Dodds et al., 1984; Dodds, 1993). Desta maneira, a presença de dsRNA vem sendo utilizada como um indicativo de infecção viral (Valverde et al., 1990) e sua detecção pode ser observada através de perfis eletroforéticos como peso molecular e número de bandas (Dodds et al., 1984). Os dsRNAs extraídos também tem sido utilizados para se obter diretamente o genoma viral para estudos moleculares.

A partir de dsRNA extraídos de lesões de leprose, Rodrigues (2000) obteve duas bandas de alto peso molecular de aproximadamente $10 \mathrm{~kb}$ e $5 \mathrm{~kb}$, proveniente de tecidos foliares com sintomas de leprose de plantas do campo, assim como de plantas infectadas em condições controladas. Materiais sadios não apresentaram bandas, indicando ser o CiLV um vírus que apresenta dsRNA em alguma fase do seu ciclo replicativo. Rodrigues (2000) também observou em outras plantas como ligustre e café, bandas correspondentes ao dsRNA, sugerindo que outros vírus transmitidos pelo ácaro Brevipalpus também apresentam esta característica molecular. A associação de moléculas de dsRNA com materiais vegetais infectados com CiLV representa uma alternativa para a caracterização de seu genoma, bem como para o desenvolvimento de sistemas de diagnose da doença (Colariccio et al., 2000; Rodrigues et al., 2000; Locali et al., 2003a; Antonioli et al., 2003). A extração de dsRNA tem 
possibilitado a obtenção de parte do genoma viral de CiLV (provável gene da proteína de movimento e da replicase) a partir dos quais foram produzidos primes para amplificação por RT-PCR que são usados na diagnose (Locali et al., 2003b). Recentemente foi obtida a seqüência completa do CiLV (R. Pascon, comunicação pessoal).

Devida certa semelhança morfológica das partículas dos vírus transmitidos por Brevipalpus, alguns deles como a leprose dos citros, "orchid fleck" e mancha anular do café, acha-se tentativamente incluído entre os rhabdovirus. Rhabdovirus (rhabdo vem do grego e significa haste) são vírus cujo genoma é constituído de RNA fita simples negativa não segmentado e nucleocapsídeo. São envolvidos por um envelope lipídico, indicando glicoproteínas de superfície. As partículas são baciliformes, medindo entre 45 a $95 \mathrm{~nm}$ de diâmetro e 180 - $380 \mathrm{~nm}$ de comprimento. Esse grupo é dividido em seis gêneros, sendo que os rhabdovirus em plantas se classificam de acordo com a localização de maturação do vírus na célula hospedeira, isto é, Nucleorhabdovirus (núcleo) e Cytorhabdovirus (citoplasma) (Francki et al., 1981; ICTV, 2002).

Existem, no entanto, muitas doenças de plantas associadas a partículas virais semelhantes a rhabdovirus que ainda não foram incluídas em nenhum gênero específico. Nestes casos, sua indicação como possível membro desta família se deve apenas a características morfológicas e não físico-químicas (Francki et al., 1981; ICTV, 2002).

A purificação das partículas do OFV e o seqüenciamento de seu genoma reforçaram sua indicação como um membro tentativo de rhabdovirus. Isto porque Kondo et al. (1998), ao seqüenciarem parte do genoma deste vírus, demonstraram que ele é um ssRNA, senso negativo, bipartido e apresenta organização genômica similar a da família Rhabdoviridae. Blanchfield et al. (2001) comparou seqüências do nucleocapsídeo, amplificados por RT-PCR de isolados de OFV procedentes de diferentes partes do mundo demonstrando semelhanças. Entretanto, a organização genômica do CiLV citoplasmática, 
apesar de ser bipartido, é bastante distinta, pois possui um senso positivo e a replicase tem homologia com o grupo do Tobamovirus, sugerindo que o mesmo possa ser um novo gênero dentro deste grupo (Locali, 2002; Guerra-Moreno et al., 2004; R. Pascon, comunicação pessoal).

Além das características morfológicas, são desejáveis dados sobre as propriedades físico-químicas e antigênicas para a correta classificação destes vírus. No caso do CiLV-C, diversos protocolos (Doi et al., 1977; Hsu e Black, 1973; Ávila et al., 1990; Derrick et al., 1988 e Lane, 1992) já foram adotados na tentativa de purificá-lo, utilizando tecidos com lesões de leprose de laranja doce "Pêra" e tangerina "Cleópatra" (Lovisolo et al., 1996). No entanto nenhuma das preparações obtidas foi infecciosa e partículas virais não foram detectadas através de microscopia eletrônica. Colariccio et al. (2000), tentando purificar CiLV, obtiveram partículas curtas e irregularmente baciliformes medindo cerca de 45-50 X 80-120 nm, sugerindo se tratar de virions do CiLV. Porém não foi possível a visualização das estruturas internas das partículas.

2.4 Morfologia e citopatologia dos vírus transmitidos por Brevipalpus spp.

Os primeiros relatos eletron-microscópicos de vírus deste grupo foram feitos em tecidos de orquídeas infetados pelo OFV no final da década dos 60, embora a comprovação de que era transmitido por ácaro tenha sido feita apenas em 1996. Partículas em forma de bastonetes ocorriam no núcleo ou citoplasma, e no núcleo se formava um viroplasma de baixa densidade eletrônica (Doi et al., 1977). Esta observação foi confirmada em várias partes do mundo, inclusive no Brasil (Duvel \& Peters, 1971; Lesemann \& Begtrup, 1971; Petzold, 1971; Begtrup, 1972; Kitajima et al., 1974a). Observações similares foram feitas em um isolado da leprose dos citros (Kitajima et al., 1972) e mancha anular do cafeeiro (Kitajima \& Costa, 1972; Chagas, 1980). Contudo, em amostras com "lepra explosiva" da Argentina (Kitajima et al., 1974b) e em 
outros isolados da leprose no Brasil (Colariccio et al., 1995) foram encontradas outro padrão citopatológico, representado por partículas baciliformes, com membrana, em cavidades do retículo endoplasmático e a presença de um viroplasma eletron-denso. Este tipo de efeito citopático foi constatado também associada à mancha anular do ligustro (Lima et al., 1991) e pinta verde do maracujazeiro (Kitajima et al., 1997). Isto evidenciou o fato de que há dois padrões citopáticos induzidos pelos vírus transmitidos por Brevipalpus e que se convencionou designar de nuclear e citoplasmática, respectivamente (Kitajima et al., 2003). Outros vírus transmitidos por Brevipalpus ou associados à sua infestação descritos posteriormente mostram, consistentemente um destes efeitos citopatológicos.

Os vírus transmitidos por Brevipalpus apresentam algumas semelhanças com os rhabdovirus de plantas. Contudo são mais delgados quando possuem membranas, como no tipo citoplasmático tendo $50-60 \mathrm{~nm}$ de largura, contra 60-80 nm dos rhabdovirus, e sem membrana, como no tipo nuclear, 40-50 nm de largura. Os rhabdovirus de plantas são divididos em 2 gêneros, de acordo com a sua localização, Nucleorhabdovirus e Cytorhabdovirus (Wunner et al., 1995). O viroplasma intranuclear do OFV deve representar acúmulo de proteínas estruturais de vírus, pois foi imunomarcado com anticorpo específico contra este vírus purificado (Kitajima et al., 2001b).

2.5 Transmissão mecânica dos vírus transmitidos por Brevipalpus spp.

Dentre os vírus transmitidos pelos ácaros Brevipalpus, OFV foi o primeiro a ser transmitido mecanicamente inclusive para hospedeiras nãoorquidáceas (Doi et al., 1977). Chagas et al., (1981) conseguiram transmitir a mancha anular do cafeeiro para cafeeiro e algumas outras espécies de plantas enquanto Colariccio et al. (1995) relataram a transmissão mecânica da leprose dos citros para citros e outras espécies vegetais. 
Dentre os outros vírus transmitidos por Brevipalpus em ornamentais, a mancha anular de S. violaefolium foi transmitido com relativa facilidade para numerosas outras espécies (Kitajima \& Moraes, 2000, Kitajima et al., 2001a). $\mathrm{Na}$ Australia, a transmissão mecânica da mancha clorótica de Viola para outras espécies de violeta, que tem efeito citopático do tipo nuclear, foi relatada e embora não haja ainda evidências de sua transmissão com Brevipalpus, o efeito citopático mostra o mesmo padrão dos vírus transmitidos por estes ácaros (Gowanlock \& Dietzegen, 1995). O vírus da mancha clorótica de Clerodendron (tipo nuclear) pode ser transmitido mecanicamente para algumas plantas testes (Ferreira et al., 2003). OFV e CoRSV quando inoculados mecanicamente em plantas testes como Chenopodium quinoa Willd., C. amaranticolor Coste \& Ryn, espinafre da Nova Zelândia (Tetragonia expansa Murr) causam lesões locais, e se estas plantas forem mantidas a temperaturas altas (cerca de $28^{\circ} \mathrm{C}$ ), após duas semanas ocorre infecção sistêmica (Doi et al., 1977; Boari et al., 2003). 


\section{MATERIAL E MÉTODOS}

\subsection{Vírus}

Isolado do vírus da mancha anular de S. violaefolium (Solanum violaefolium ringspot vírus - SVRSV) foram originalmente encontrado e isolado nos jardins do Hotel Beira Rio e do Clube de Campo de Piracicaba, SP e mantido em condições de casa-de-vegetação por transmissão com o vetor Brevipalpus phoenicis e transmissão mecânica. Esse isolado foi utitilizado para realização dos ensaios de transmissão, para purificação e para o seqüenciamento.

\subsection{Ensaios de transmissão}

3.2.1 Transmissão mecânica em plantas indicadoras

Extratos de folhas de plantas de S. violaefolium foram obtidos por trituração em um almofariz na presença de tampão fosfato $\left(\mathrm{NaHPO} \mathrm{O}_{4}+\mathrm{KH}_{2} \mathrm{PO}_{4}\right.$ $0,01 \mathrm{M}, \mathrm{pH} 7,2)$ contendo sulfito de sódio $0,1 \%$, numa concentração final de $2 \mathrm{~g}$ de tecido com lesão para $10 \mathrm{ml}$ do tampão fosfato. Este extrato foi aplicado, mediante fricção nas folhas das plantas em teste, previamente polvilhadas com carborundum. Esses extratos foram mantidos à baixa temperatura usando vasilhames com gelo.

As espécies de plantas usadas para a inoculação mecânica estão relacionadas abaixo na tabela 2 . 
Tabela 2. Plantas usadas para testes de inoculação mecânica e inoculação por meio de ácaros

\begin{tabular}{|c|c|c|}
\hline Nome científico & Família & Nome comum \\
\hline Bidens pilosa L. & Compositae & Picão preto \\
\hline Cajanus cajan L. & Fabacea & Guandu cv Anão IAPAR 43 \\
\hline C. cajan L. & Fabacea & Guandu cv Fava larga \\
\hline Capsicum annuum L. & Solanaceae & Pimentão \\
\hline Carica papaya L. & Caricaceae & Mamoeiro \\
\hline Chenopodium quinoa Willd. & Chenopodiacea & Quenopódio \\
\hline C. amaranticolor Coste \& Ryn. & Chenopodiacea & Quenopódio \\
\hline Citrus sp L. & Rutaceae & Laranjeira \\
\hline Clerodendron $x$ speciosum & Verbenaceae & Lágrima de cristo \\
\hline Coffea arabica L. & Rubiaceae & Cafeeiro \\
\hline Crotalaria juncea L. & Fabacea & Crotalária \\
\hline C. breviflora DC & Fabacea & Crotalária \\
\hline C. mucronata Desv & Fabacea & Crotalária \\
\hline C. ochroleuca G. Don & Fabacea & Crotalária \\
\hline Cymbidium sp. & Orchidacea & Orquídea \\
\hline Datura suaveolens (Willd.) Bercht. & Solanaceae & Datura \\
\hline \multicolumn{3}{|l|}{ \& J. Presl } \\
\hline D. stramonium L. & Solanaceae & Datura, sete-saias \\
\hline Dolichos lab-lab L. & Fabacea & Labe-labe cv Rongai \\
\hline Gomphrena globosa L. & Amaranthaceae & Perpétua \\
\hline Hisbiscus cannabinus L. & Malvaceae & Kenaf \\
\hline Lactuca sativa L. & Compositae & Alface \\
\hline Lycopersicum esculentum Mill. & Solanaceae & Tomate \\
\hline Manihot esculentum Crantz & Euphorbiaceae & Mandioca \\
\hline Nicotiana benthamiana & Solanaceae & Fumo \\
\hline N. clevelandii & Solanaceae & Fumo \\
\hline N. glutinosa L. & Solanaceae & Fumo \\
\hline N. rustica L. & Solanaceae & Fumo \\
\hline N. sylvestris Speg. \& Come & Solanaceae & Fumo \\
\hline N. tabacum L. & Solanaceae & Fumo \\
\hline Passiflora edulis Sims & Passifloraceae & Maracujazeiro \\
\hline Pfaffia sp. (Mart.) Kuntze & Amaranthaceae & Fáfia, para-tudo \\
\hline
\end{tabular}


Tabela 2. Plantas usadas para testes de inoculação mecânica e inoculação por meio de ácaros

\begin{tabular}{lll}
\hline Nome científico & Família & Nome comum \\
\hline Phaseolus vulgaris L. & Fabacea & Feijão \\
Solanum vioalefolium Bitter & Solanaceae & Solano-violeta \\
Stizolobium atterrimum & Fabacea & Mucuna cinza \\
S. atterrimum & Fabacea & Mucuna anã \\
S. atterrimum & Fabacea & Mucuna preta \\
Thunbergia erecta & Acantaceae & Manta-do-rei \\
Zinnia elegans Jacq. & Asteracea & Zínia \\
\hline
\end{tabular}

Foram inoculadas $S$. violaefolium e plantas testes habituais, além de outras espécies nas quais ocorrem vírus transmitidos por Brevipalpus (Tabela 2). Após a inoculação as plantas foram mantidas em condições de casa-devegetação e a leitura de sintomas feita diariamente. Em alguns casos, as plantas foram submetidas a temperatura constante de $30^{\circ} \mathrm{C}$, na tentativa de provocar uma infecção sistêmica (Boari et al., 2003).

\subsubsection{Transmissão pelo ácaro B. phoenicis}

Colônias de B. phoenicis, obtidas a partir de ovos coletados em $S$. violaefolium, foram mantidas em frutos de laranja. Estes ácaros foram transferidos, utilizando-se um pincel de ponta fina $\left(n^{\circ} 4\right)$, para plantas de $S$. violaefolium infectadas pelo SvRSV para um período de 3 a 5 dias de alimentação para aquisição. Os ácaros ficaram restritos a área da lesão por meio de uma mistura de areia, gesso e cola, distribuída suavemente por cima da lesão e rodeado por uma barreira de cola. Em seguida os ácaros foram transferidos para plantas-testes sadias, nas quais permaneciam para um período de três dias de alimentação para inoculação. Ao final deste, os ácaros foram eliminados com acaricida, fazendo-se leituras do aparecimento de sintomas em intervalos de 2-3 dias. 
A presença de vírus nas lesões foi averiguada por técnicas de microscopia eletrônica de transmissão e inoculação mecânica em planta-teste.

Também foram coletados ácaros diretamente de plantas com sintomas de SvRSV para obtenção de fonte de inoculo livre de outros vírus.

\subsection{Microscopia}

\subsubsection{Microscopia eletrônica de varredura (MEV)}

Esta metodologia foi utilizada principalmente para análise da morfologia externa do ácaro para sua identificação, baseada em características morfológicas como o número de solenídeos no $2^{\circ}$ par de pernas e de setas dorsais em adultos (Baker, 1949). Os ácaros foram coletados em folhas de $S$. violaefolium do Clube de Campo, Hotel Beira Rio e Biblioteca Municipal de Piracicaba - SP.

\subsubsection{Fixação}

Adultos de Brevipalpus sp., colocados em "gaiolas", foram pré-fixados em uma solução de 2,5\% de glutaraldeído, 2,5\% de paraformaldeído em tampão cacodilato $\mathrm{pH} 7(0,05 \mathrm{M})$ com $\mathrm{CaCl}_{2}$ (Karnovsky modificado) por pelo menos uma hora (Kitajima \& Leite, 1999). A solução foi descartada, em seguida foi colocado tampão cacodilato $0,05 \mathrm{M}$ três vezes. Em seguida foi feita uma pósfixação com tetróxido de ósmio $\left(\mathrm{OsO}_{4}\right)$ por 1 hora.

\subsubsection{Desidratação, secagem ao ponto crítico e metalização}

O tetróxido de ósmio foi descartado e as amostras foram lavadas com água destilada, sendo submetidas a soluções crescentes de acetona (30, 50, 70 e $90 \%$ ) por 10 min, em seguida uma solução de acetona $100 \%$ foi colocada nas 
amostras por 3 vezes. Para eliminar a umidade nas amostras, as mesmas são submetidas ao aparelho de secagem ao ponto crítico, onde se substitui a acetona pelo gás carbônico, o qual é eliminado pela elevação da temperatura (Bray, 1993). As amostras foram metalizadas com ouro e em seguida, visualizadas ao microscópio eletrônico de varredura (MEV - DSM940 A e LEO).

\subsubsection{Microscopia eletrônica de transmissão (MET)}

Observações das partículas virais em extratos de folhas, de ácaros ou em preparações purificadas foram feitas em preparações contrastadas negativamente com acetato de uranila ou silicotungstato de sódio. Para avaliar os efeitos citopatológicos os tecidos (plantas infetadas) das amostras foram preparados de acordo com Kitajima (1998) e Kitajima \& Nome (1999).

\subsubsection{Fixação e emblocamento}

Amostras de tecidos foram pré-fixadas em uma solução de Karnovisk modificado (mesmo utlizado para microscopia de varredura) por pelo menos 1 h. Após a lavagem 3 vezes por $10 \mathrm{~min}$ em tampão cacodilato $0,05 \mathrm{M}$, as amostras foram fixadas em ácido ósmico $\left(\mathrm{OsO}_{4}\right)$ em tampão cacodilato $0,05 \mathrm{M}$ por cerca de $1 \mathrm{~h}$. As amostras foram lavadas com água destilada e fixadas com acetato de uranila $0,5 \%$ durante 16 horas. Foi feita uma desidratação das amostras em uma diluição seriada de acetona $(30,50,70$ e, 90), cerca de 10 min cada e $10 \mathrm{~min}$ por 3 vezes com acetona 100\%. As amostras foram infiltradas com uma mistura de acetona e resina "spurr" (1:1) durante 3 horas e, finalmente, com resina "spurr" pura durante 16 horas. Para polimerizar, as amostras foram colocadas em formas de silicone junto com resina pura durante $48 \mathrm{~h}$ a $70^{\circ} \mathrm{C}$. Essa resina serve como suporte para os cortes ultrafinos. 


\subsubsection{Ultramicrotomia}

Para a obtenção de secções ultrafinas, as amostras em resina foram desbastadas utilizando um "trimer" (Leica EM Trim). Em seguida foram feitas secções ultrafinas no ultramicrótomo (ultracut E - Reichert), usando navalha de vidro ou de diamante. As secções foram colocadas em suportes específicos (telinhas).

\subsubsection{Contrastação}

As secções foram contrastadas utilizando uma solução de acetato de uranila a $3 \%$ e citrato de chumbo. As "telinhas" com as secções foram colocadas sobre uma gota do contrastante por cerca de 10 min. Em seguida foram mergulhadas 10 vezes em um Becker com água destilada e secas com um auxílio de papel filtro. A visualização das secções foram feita ao microscópio eletrônico de transmissão (Zeiss EM 900).

\subsubsection{Microscopia de luz}

Aspectos anatômicos das lesões em tecidos foliares foram analisados segundo metodologia de utilizada por Gloria et al., (1995). Para análises morfoanatômicas dos tecidos de S. violaefolium, as amostras das folhas sadias e com lesões foram fixadas em solução de Karnovsky. As amostras foram desidratadas numa série de etanol (30,50,70, 90 e 100\%) e infiltradas com a resina glicol metacrilato da Reichert-Jung. Foram feitas secções de $5 \mu \mathrm{m}$ de espessura em micrótomo rotativo manual. Estas secções foram coradas com azul de toluidina e montadas em resina sintética "Entellan" (Merck). As imagens foram observadas em um microscópio de luz (Zeiss) e as imagens capturadas por meio de uma câmera digital ligada ao computador. 


\subsection{Determinação de propriedades físicas in vitro}

Embora não seja mais considerado como parâmetros importantes, as propriedades físicas in vitro fornecem informações sobre a estabilidade dos vírus e assim sua determinação foi incluída neste trabalho. O extrato bruto feito a partir de lesões com sintomas de SvRSV foi coado e submetido aos tratamentos de diluição, temperatura e conservação, para se determinar, respectivamente, as seguintes propriedades físicas in vitro do vírus: ponto final de diluição, ponto de inativação térmica e conservação in vitro. A metodologia adotada para determinação das propriedades físicas in vitro foi àquela citada por Ross (1964) e também por Chagas (1978b) com adaptações.

Para cada repetição foram utilizadas quatro plantas de Datura stramonium, distribuídas em 2 vasos de $10 \mathrm{~cm}$ de diâmetro. Três repetições foram feitas para cada teste. As plantas de datura foram usadas nestes ensaios, pois se mostraram como boa espécie indicadora do vírus.

(a) Ponto final de diluição do vírus

Dois gramas de tecido com lesão de SvRSV em datura foi macerado em

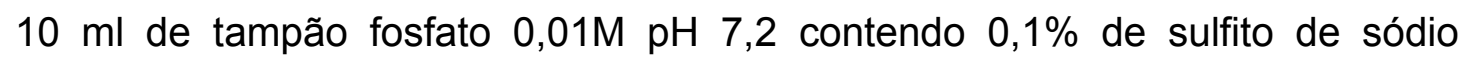
(NaSO3). Em seguida, $1 \mathrm{ml}$ desse extrato foi diluído em $9 \mathrm{ml}$ do tampão fosfato, obtendo-se uma diluição 1:10. Foram feitas várias diluições até atingir uma diluição final de $10^{-7}$. Plantas de datura sadia foram inoculas com cada uma das diluições e a observação do aparecimento de sintomas foi feita diariamente durante 15 dias.

(b) Ponto de inativação térmica do vírus

Para determinação do ponto de inativação térmica, porções do suco bruto foram colocadas em pequenos tubos em banho-maria e submetidos à temperatura que variaram de $30^{\circ} \mathrm{C}$ a $70^{\circ} \mathrm{C}$ com diferenças crescentes de $10^{\circ} \mathrm{C}$ 
durante 10 minutos. Após o tratamento térmico, cada porção relativa a uma deteminada temperatura foi inoculada em $D$. stramonium e mantida em observação durante 15 dias.

(c) Conservação do vírus

O inoculo do vírus $(20 \% \mathrm{p} / \mathrm{v})$ foi conservado em frascos à temperatura ambiente (Lovisolo et al., 2000) e inoculados em D. stramonium em tempos sucessivamente maiores até o $25^{\circ}$ dia.

As leituras dos sintomas foram feitas em intervalos diários após a inoculação.

\subsection{Purificação}

Plantas de datura foram transplantadas em vasos com capacidade para 3 litros. Após 15 dias do transplante as plantas foram inoculadas com SvRSV. Após o aparecimento de sintomas, cerca de 10 dias, as folhas foram coletadas para o procedimento de purificação.

Utilizou-se desses procedimentos para purificar o vírus de material de $S$. vioalefolium coletado diretamente do campo.

\subsubsection{Tentativa de purificação usando protocolo para rhabdovirus}

Foram utilizados protocolos para purificação de Rhabdovirus, partícula completa e nucleocapsideo viral que se acumulam nas células (Jackson \& Wagner, 1998).

$60 \mathrm{~g}$ de folhas com lesões foram trituradas por $1 \mathrm{~min}$. em tampão de extração $(0,1 \mathrm{M}$ Tris- $\mathrm{HCl}, 0,01 \mathrm{M}$ acetato de magnésio, 0,04 $\mathrm{M}$ de sulfito de sódio, 0,001 $\mathrm{M}$ de cloreto de manganês), $\mathrm{pH}$ 8,4. Em seguida, o extrato foi filtrado em gaze, seguida de uma centrifugação a $3000 \mathrm{~g}$ por $10 \mathrm{~min}$. O sobrenadante foi coletado, ajustado o $\mathrm{pH}$ para 7,5 e colocado num gradiente 
descontínuo de sacarose (60 e $30 \%$ ), centrifugado a $110.000 \mathrm{~g}$. A banda formada entre as concentrações diferentes de sacarose foi coletada e diluída em igual volume de tampão de manutenção $\mathrm{pH}$ 7,5 $(0,1 \mathrm{M}$ Tris- $\mathrm{HCl}, 0,01 \mathrm{M}$ acetato de magnésio, 0,04 $\mathrm{M}$ de sulfito de sódio, 0,001 $\mathrm{M}$ de cloreto de manganês). Após adicionar um $\mathrm{g}$ de celite à suspensão, esta foi filtrada em celite (camada de $0,5 \mathrm{~cm}$ diluída em tampão de manutenção) utilizando uma bomba de vácuo. O filtrado foi centrifugado a $90.000 \mathrm{~g}$ por $30 \mathrm{~min}$. $\mathrm{O}$ sobrenadante foi descartado e o precipitado foi ressuspendido em $1 \mathrm{~mL}$ de tampão de manutenção, o qual foi colocado em um gradiente de sacarose $(5$, 10, 20 e 30\%) preparado no dia anterior em tampão de manutenção e centrifugado a $110.000 \mathrm{~g}$ por $30 \mathrm{~min}$. A banda formada foi coletada e centrifugada a $100.000 \mathrm{~g}$ por $30 \mathrm{~min}$ em tampão de manutenção. As etapas da purificação foram acompanhadas por inoculação em plantas indicadoras e observação em microscópio eletrônico de transmissão.

3.5.2 Tentativa de purificação usando protocolo para partícula completa de tospovirus

Essa purificação foi feita usando o protocolo usado por Ávila et al. (1993).

Folhas com sintomas foram homegenizadas com tampão de extração, 3 $\mathrm{mL}$ por $\mathrm{g}$ de folha $\left(0,1 \mathrm{M} \mathrm{NaH}_{2} \mathrm{PO}_{4} \cdot \mathrm{H}_{2} \mathrm{O}, 0,01 \mathrm{M} \mathrm{NaSO}_{3}, 1 \mathrm{mM} \mathrm{PMSF}\right)$ por alguns segundos. $O$ extrato foi filtrado em gazes e centrifugado por $10 \mathrm{~min}$ a 10.000 RPM (Sorvall, rotor GSA). O sobrenadante foi descartado e o precipitado foi ressuspendido em tampão de ressuspensão $(0,01 \mathrm{M}$ $\mathrm{NaH}_{2} \mathrm{PO}_{4} \cdot \mathrm{H}_{2} \mathrm{O}, 0,01 \mathrm{~m} \mathrm{Na}_{2} \mathrm{SO}_{3}, \mathrm{pH} 7,0$ ) sem agitação, usando $2 \mathrm{~mL} / \mathrm{g}$ de folha, agitado gentilmente por 1 hora. A suspensão foi centrifugada por $10 \mathrm{~min}$ a 10.000 RPM (Rotor SS 34, Sorvall). O sobrenadante foi centrifugado por $30 \mathrm{~min}$ a 30.000 RPM (Rotor T30, Beckman). Foi adicionado ao "pellet", 0,15 mL de tampão de ressuspensão por grama de folha e agitado suavemente por $30 \mathrm{~min}$. em gelo. A suspensão foi colocada num gradiente de sacarose $5-40 \%$ 
(preparado no dia anterior em tampão de ressuspensão) e centrifugada por 45 min a 23.000 RPM (Rotor SW41, Beckman). As etapas da purificação foram acompanhadas por inoculação em plantas indicadoras e observação em microscópio eletrônico de transmissão.

Ainda foram utilizados diversos protocolos adaptados para purificar a partícula completa e o nucleocapsídeo (Chu \& Yeh, 1998; Kato et al., 1999).

\subsection{Seqüenciamento de fragmentos do genoma viral}

Todas as etapas referentes ao processo de seqüenciamento de fragmentos do SvRSV foram feitas no laboratório de biotecnologia do Centro APTA Citros "Sylvio Moreira"/IAC. As metodologias usadas para esses procedimentos foram baseadas em Sambrook et al. (1989) e Locali (2002) com algumas adaptações.

\subsubsection{Isolamento de RNA dupla fita (dsRNA)}

Plantas de datura inoculadas com SvRSV foram usadas para isolar o dsRNA do vírus, segundo protocolos de Valverde et al. (1990) Com pequenas modificações, conforme descrito em Locali (2002). Dois gramas do tecido infectado foram triturados em um almofariz com o auxílio de nitrogênio líquido, sendo transferidos para tubos de centrífuga de $50 \mathrm{~mL}$ contendo $7,0 \mathrm{~mL}$ de $2 \mathrm{x}$ STE (1x STE = 0,05 M Trizma base; 0,1 M NaCl; 0,001 M EDTA pH 6,8); 7,0 $\mathrm{mL}$ de fenol; $7,0 \mathrm{~mL}$ de clorofórmio:álcool isoamílico (24:1); $1,6 \mathrm{~mL}$ de $20 \%$ SDS. Os tubos em seguida foram agitados durante $30 \mathrm{~min}$ a temperatura ambiente e centrifugados a $8.000 \mathrm{xg}$, a $4{ }^{\circ} \mathrm{C}$, durante $10 \mathrm{~min}$. Ao final desta etapa a fase líquida foi transferida para outro tubo, a concentração do etanol foi ajustada para $16 \%$ e, em seguida, foi aplicada em uma coluna de CF-11 (Celulose Fibrosa - Whatman) (Choi \& Randles, 1997) preparada em 1X STE contendo $16 \%$ de etanol ( $2 \mathrm{~g} \mathrm{CF}-11 ; 50 \mathrm{~mL}$ de $1 \mathrm{X}$ STE $+16 \%$ etanol). Lavou-se 
a coluna com $80 \mathrm{~mL}$ de 1 X STE contendo $16 \%$ etanol e com $5 \mathrm{~mL}$ de 1 X STE. O dsRNA foi eluído com $20 \mathrm{~mL}$ de 1 X STE, adicionando-se etanol ao eluído para uma concentração final de $16 \%$. A amostra foi aplicada em uma segunda coluna de CF-11 usando 1 grama de CF-11 diluída em $35 \mathrm{~mL}$ de 1 X STE com $16 \%$ de etanol. A coluna foi lavada com $2,5 \mathrm{~mL}$ de 1 X STE e o dsRNA foi eluído em $6 \mathrm{~mL}$ de 1X STE. A precipitação do dsRNA foi feita com 0,1 volumes de $3 \mathrm{M}$ de acetato de sódio $\mathrm{pH} \mathrm{5,2} \mathrm{e} 3$ volumes de etanol, durante $16 \mathrm{~h}$ a $-20^{\circ} \mathrm{C}$. O tubo foi centrifugado a $12.000 \times \mathrm{g}$ durante 25 min a $4{ }^{\circ} \mathrm{C}$, lavado com $70 \%$ etanol, seco em liofilizador e ressuspendido em $25 \mu \mathrm{L}$ de água destilada. A análise do dsRNA foi feita através de eletroforese em gel de agarose $1 \%$ preparado em TAE (0,04 M Tris-acetato; 0,001 M EDTA) contendo 0,5 ug/mL de brometo de etídio.

\subsubsection{Purificação do dsRNA}

O dsRNA do SvRSV obtido foi submetido a um tratamento utilizando enzimas específicas para eliminar possíveis contaminações com material genômico da planta (ssRNA e DNA).

\subsubsection{Digestão do dsRNA do SvRSV com Mung Bean Nuclease}

A reação de digestão foi feita em microtubo de 1,5 mL estéril, para evitar qualquer tipo de contaminação do tipo ssRNA e ssDNA proveniente da planta. A reação foi constituída aproximadamente de 300 a 600 ng de dsRNA, $12 \mu \mathrm{L}$ de tampão (Buffer 10X Mung Bean Nuclease - Gibco) da enzima, $3 \mu \mathrm{L}$ da enzima Mung Bean Nuclease (Gibco) 13,5 U e $\mathrm{H}_{2} \mathrm{O}$ Milli-Q autoclavada q.s.p. $5 \mu \mathrm{L}$ e incubada a $30^{\circ} \mathrm{C}$ durante $30 \mathrm{~min}$. Amostras de RNA total extraído de plantas de orquídea com e sem OFV foi usada como controle da reação de digestão que foi em seguida submetida à eletroforese em gel de agarose $1 \%$ para avaliação da concentração do dsRNA. O dsRNA digerido foi precipitado com 1:10 volume 
de acetato de sódio $3 \mathrm{M} \mathrm{pH} \mathrm{4,8} \mathrm{e} 3$ volumes de etanol 100\%. Em seguida foi centrifugada por $30 \mathrm{~min}$ a $12000 \mathrm{RPM}$ a $4{ }^{\circ} \mathrm{C}$. O "pellet" foi liofilizado e ressuspendido em $200 \mu \mathrm{L}$ de $\mathrm{H}_{2} \mathrm{O}$ Milli-Q autoclavada.

\subsubsection{Digestão do dsRNA do SvRSV com DNAse I - RNAse free}

Foram adicionados aos $200 \mu \mathrm{L}$ de volume final obtidos no item anterior 1 $\mu \mathrm{L}$ de inibidor de RNAse (RNAse - inhibitor cloned - Invitrogen) $10 \mathrm{U}, 50 \mu \mathrm{L}$ do tampão $5 X\left(50 \mathrm{mM} \mathrm{MgCl}_{2} ; 50 \mathrm{mM}\right.$ Tris pH 7,5; 5 mM EDTA pH 8,0; $5 \mathrm{mM}$ DTT) da enzima DNAse I RNAse-free (Boehringer Mannheim $\mathrm{GmbH}$ ) e $1 \mu \mathrm{L}$ da enzima DNAse I RNAse-free (Boehringer Mannheim GmbH) $10 \mathrm{U} / \mu \mathrm{L}$. Encubouse essa reação durante 30 min a $37^{\circ} \mathrm{C}$. Além do dsRNA do SvRSV foi utilizada uma amostra de DNA extraído de planta de laranjeira sadia como controle da reação de digestão que foi em seguida submetida à eletroforese em gel de agarose $1 \%$ para avaliação da concentração do dsRNA. Após esta etapa, foi feita uma extração da reação com um volume de fenol:clorofórmio:álcool isoamílico (25:24:1) agitado rapidamente e centrifugado durante 3 min a $5.900 \mathrm{x}$ g. Ao sobrenadante coletado para outro microtubo foi colocado o mesmo volume de fenol:clorofórmio (1:1), e centrifugado durante 3 min a $5.900 \times \mathrm{g}$. A etapa seguinte consistiu da transferência do sobrenadante para um novo microtubo e adição do mesmo volume de clorofórmio, o qual foi centrifugado a $5.900 \times \mathrm{g}$ durante $3 \mathrm{~min}$. A precipitação foi feita conforme descrito anteriormente e o "pellet" foi seco em liofilizador, tendo sido ressuspendido a amostra em 30 $\mu \mathrm{L}$ de $\mathrm{H}_{2} \mathrm{O}$ Milli-Q autoclavada.

Todo o volume desta digestão foi submetido à eletroforese em gel de agarose LMP (Low melting point) 0,8\%. As bandas do SvRSV com pesos moleculares de interesse foram cortadas do gel com auxílio de um bisturi e eluídas em 3 volumes de tampão TE 1/10 (Tris HCl $10 \mu \mathrm{M}$, pH 7.5; EDTA $1 \mu \mathrm{M}$ ) em banho-maria a $50{ }^{\circ} \mathrm{C}$ por 10 minutos. As bandas obtidas foram purificadas 
através de extração com fenol:clorofórmio (1:1) e 1 volume de clorofórmio, sendo precipitadas com $1 / 10$ do volume de acetato de sódio $3 \mathrm{M} \mathrm{pH} \mathrm{5,2} \mathrm{e}$ etanol absoluto como descrito anteriormente. O "pellet", purificado foi ressuspendido em $25 \mu \mathrm{L}$ de $\mathrm{H}_{2} \mathrm{O}$ Milli-Q autoclavada. A determinação da concentração do dsRNA purificado foi feita usando $2 \mu \mathrm{L}$ do volume final da purificação em gel de agarose $1 \%$ e submetidos à eletroforese, usando como um marcador "Lambda" com 10ng/ $\mu \mathrm{L}$.

\subsubsection{Extração de RNA total}

Cerca de 50 a $100 \mathrm{mg}$ de material fresco de tecidos de folhas de datura sadias e com sintomas de SvRSV foram macerados com o auxílio de nitrogênio líquido até a obtenção de um pó fino de acordo com protocolo de Gibbs \& Mackenzie (1997). Após adicionar $500 \mu \mathrm{L}$ do tampão de lavagem (10 mM Tris$\mathrm{HCl} \mathrm{pH} 8,0 ; 1 \mathrm{mM}$ EDTA pH 8,0; $2 \mathrm{M} \mathrm{NaCl} ; 0,05 \% \mathrm{BSA})$, as amostras foram homogenizadas com o auxílio de um vortex e centrifugadas a 13.400 x g por 5 min. O sobrenadante foi descartado e foram adicionados ao "pellet" $600 \mu \mathrm{L}$ do tampão CTAB (2\% CTAB, $1,4 \mathrm{M} \mathrm{NaCl}$ e $0,1 \mathrm{M}$ Tris- $\mathrm{HCl}$ pH 8.0) contendo $0,5 \%$ $\beta$-mercaptoetanol, agitando-o com um vortex. Após a incubação da amostra por 15 a 30 min a $55^{\circ} \mathrm{C}$, adicionou-se $400 \mu \mathrm{L}$ de clorofórmio:álcool isoamílico (24:1) agitando no vortex para homogenizar a solução. A amostra foi centrifugada a $13.400 \times \mathrm{g}$ durante $10 \mathrm{~min}$. A fase aquosa foi cuidadosamente removida e colocada em um novo microtubo. Um décimo do volume de acetato de amônio 7,5 M, bem como um volume de isopropanol, foram acrescentados ao tubo. Agitou-se bem e armazenou-se em freezer a $-20^{\circ} \mathrm{C}$ por 5 a $10 \mathrm{~min}$. A amostra foi novamente centrifugada a 13.400 x g de 5 a 10 min e o sobrenadante foi removido gentilmente para não perder o "pellet". Após a adição de $1 \mathrm{~mL}$ de etanol $70 \%$, o tubo foi centrifugado durante $1 \mathrm{~min}$ na mesma velocidade anterior, ao final do qual, descartou-se o sobrenadante. O "pellet" foi seco em 
liofilizador e $20 \mu \mathrm{L}$ de $\mathrm{H}_{2} \mathrm{O}$ DEPC foram adicionados. As amostras foram armazenadas em freezer $-80^{\circ} \mathrm{C}$.

\subsubsection{Síntese da $1^{a}$ fita do DNA complementar (cDNA)}

A síntese da primeira fita de cDNA foi feita como indicado por Sambrook et al. (1989), usando a enzima transcriptase reversa e "oligodT primers". Uma alíquota de $5 \mu \mathrm{L}$ do dsRNA obtido anteriormente foi desnaturado à $95^{\circ} \mathrm{C}$, durante $5 \mathrm{~min}$, e colocado imediatamente no gelo. Feita a desnaturação do dsRNA, foram adicionados $4 \mu \mathrm{L}$ do tampão $5 \mathrm{X}$ para transcriptase reversa, $1 \mu \mathrm{L}$ de dNTP (10mM), 0,5 $\mu \mathrm{L}(2 \mathrm{mM})$ de DTT, $1 \mu \mathrm{L}(15 \mathrm{U})$ do inibidor de RNAse (RNAse-in Invitrogen), $1 \mu \mathrm{L}$ (200U) da Transcriptase Reversa (Superscript ${ }^{\mathrm{TM}}$ II RT Invitrogen), $1 \mu \mathrm{L}$ do iniciador (OligodT - invitrogen) e água Milli-Q para um volume final de $20 \mu \mathrm{L}$. A reação foi incubada a $42{ }^{\circ} \mathrm{C}$ durante $1 \mathrm{~h}$, com uma incubação posterior de $70^{\circ} \mathrm{C}$ durante 15 min para inativar a enzima.

Para síntese da segunda fita de cDNA foi usada a enzima DNA Polimerase I (Promega). Para o preparo das reações foram adicionados $20 \mu \mathrm{L}$ da reação de cDNA primeira fita, $10 \mu \mathrm{L}$ do tampão $10 \times\left(2^{\text {nd }}\right.$ strand $)$ para DNA Polimerase I, 0,8 $\mu \mathrm{L}$ de RNAse-H $2 \mathrm{U} / \mu \mathrm{L}, 2,5 \mu \mathrm{L}$ da enzima DNA Polimerase I (9 $\mathrm{U} / \mu \mathrm{L}$ ) e $\mathrm{H}_{2} \mathrm{O}$ Milli-Q para completar o volume de $100 \mu \mathrm{L}$. A reação foi incubada durante 2 horas a $14^{\circ} \mathrm{C}$ e a $70^{\circ} \mathrm{C}$ durante 10 min para inativação da enzima.

Após a síntese da segunda fita de cDNA foi feita uma extração com um volume de fenol:clorofórmio:álcool isoamílico (25:24:1), misturado e centrifugado durante 5 min a $5.900 \times$ g. Transferiu-se o sobrenadante para outro microtubo colocando o mesmo volume de clorofórmio. O tubo foi, centrifugando durante $5 \mathrm{~min}$ a $5.900 \times \mathrm{g}$. O sobrenadante coletado foi colocado em outro microtubo, no qual se adicionou $1 / 10$ do volume de acetato de sódio $3 \mathrm{M} \mathrm{pH} \mathrm{5,2}$ e 3 volumes de etanol absoluto para precipitação em temperatura de $-20{ }^{\circ} \mathrm{C}$ durante a noite. As amostras foram centrifugadas durante 30 min a $13.400 \times \mathrm{g}$, 
descartou-se o sobrenadante e se adicionou etanol $70 \%$ para lavar o "pellet". Repetiu-se a centrifugação das amostras durante $5 \mathrm{~min}$ a $13.400 \mathrm{x}$ g. Com o auxílio de micropipeta, descartou-se o sobrenadante e o "pellet" foi seco em liofilizador. A amostra foi ressuspendida em $10 \mu \mathrm{L}$ de $\mathrm{H}_{2} \mathrm{O}$ Milli-Q autoclavada.

\subsubsection{Biblioteca}

Após a obtenção da segunda fita do cDNA, esta foi a ligada a adaptadores, amplificada por Nested PCR e purificada em gel LMP. Os fragmentos purificados foram ligados em vetor pGEM-T (Promega) de acordo recomendações do fabricante.

Para amplificar os fragmentos obtidos do cDNA do genoma viral através de "Nested PCR", o cDNA foi acoplado a adaptadores de acordo com o protocolo da "Bacterial Genome Subtraction Kit - CLONTECH PCR-SELECT", seguido de algumas modificações. Foram utilizados $6 \mu \mathrm{L}$ do cDNA segunda fita purificado, $1 \mu \mathrm{L}$ do tampão de ligação (10X), $2 \mu \mathrm{L}$ do adaptador 2 (5'CTAATACGACTCACTATAGGGCAGCGTGGTCGCGGCCGAGGT-3'), $2 \mu \mathrm{L} d a$ enzima T4 DNA ligase $400 \mathrm{U} / \mu \mathrm{L}$. Incubou-se por $16 \mathrm{~h}$ a $16{ }^{\circ} \mathrm{C}$, adicionando $1 \mu \mathrm{L}$ de EDTA $0,2 \mathrm{M}$ à reação, incubando-a em seguida durante $5 \mathrm{~min}$ a $72^{\circ} \mathrm{C}$ para inativação da enzima. Esta etapa foi realizada para fazer a reação de ligação aos adaptadores.

Para primeira amplificação da reação, usou-se $3,0 \mu \mathrm{L}$ do cDNA ligado ao adaptador 2; $2,5 \mu \mathrm{L}$ de tampão de PCR 10X; $1,25 \mu \mathrm{L}$ de $\mathrm{MgCl}_{2}, 1 \mu \mathrm{L}$ do "primer" 2 (5'-AGCGTGGTCGCGGCCGAGGT-3'), 0,5 $\mu$ L do dNTP (mix) 10 mM , $1 \mu \mathrm{L}$ da enzima Taq DNA Polimerase, completando o volume de $25 \mu \mathrm{L}$ com água Milli-Q. O termociclador foi programado com 1 ciclo de $72^{\circ} \mathrm{C}$ por $10 \mathrm{~min}, 1$ ciclo de $94{ }^{\circ} \mathrm{C}$ por $10 \mathrm{~min}, 35$ ciclos de $94^{\circ} \mathrm{C}$ por $1 \mathrm{~min}, 66^{\circ} \mathrm{C}$ por 30 segundos, $72{ }^{\circ} \mathrm{C}$ por 1 min e 30 segundos. 
Após diluir o produto da primeira reação 1:9, usou-se essa alíquota como molde para a segunda reação, que foi elaborada com 5,0 $\mu \mathrm{L}$ do cDNA amplificado e diluído, 2,5 $\mu \mathrm{L}$ de tampão de PCR 10X, 1,25 $\mu \mathrm{L}$ de $\mathrm{MgCl}_{2}, 1 \mu \mathrm{L}$ "Nested primer 2 (5'-TCGAGCGGCCGCCCGGGCAGGT-3')", 0,5 $\mu \mathrm{L}$ do dNTP (mix) $10 \mathrm{mM}, 1 \mu \mathrm{L}$ da enzima Taq DNA Polimerase e $\mathrm{H}_{2} \mathrm{O}$ Milli-Q para completar o volume de $25 \mu \mathrm{L}$. O programa de termociclagem consistiu do mesmo usado anteriormente. Ao final desta reação, submeteu-se o produto de $\mathrm{PCR}$ à eletroforese em gel LMP $0,8 \%$, os fragmentos amplificados foram purificados do gel com o Kit QIAGEN (QIAquick - gel Extraction kit) e utilizados para clonagem.

Utilizou-se $10 \mu \mathrm{L}$ do produto da PCR purificado na reação de ligação adicionando 1,0 $\mu \mathrm{L}$ do vetor pGEM-T (50 ng/ $\mu \mathrm{L}$ ), 1,3 $\mu \mathrm{L}$ do tampão de ligação 10X e $1,0 \mu \mathrm{L}$ da enzima T4 DNA ligase. A reação foi incubada durante $16 \mathrm{~h}$ a 4 ${ }^{\circ} \mathrm{C}$. Ao final desta etapa, o plasmídeo recombinante foi inserido em células competentes de Escherichia coli da linhagem DH5 $\alpha$ através de transformação por choque térmico (Sambrook et al., 1989). Sendo assim, 13,3 $\mu \mathrm{L}$ da reação de ligação foram colocados em $50 \mu \mathrm{L}$ de células competentes de $\mathrm{DH} 5 \alpha$ retiradas do freezer $-80{ }^{\circ} \mathrm{C}$ momentos antes. O tubo contendo a reação de ligação junto com as células competentes foi incubado em gelo durante $1 \mathrm{~h}$, e transferido para banho-maria à $42^{\circ} \mathrm{C}$ durante $1 \mathrm{~min}$ e trinta segundos, quando foi transferido imediatamente para gelo por $2 \mathrm{~min}$. Cada tubo recebeu $937 \mu \mathrm{L}$ de meio SOC (10 g de bacto triptona, $5 \mathrm{~g}$ de extrato de levedura, 0,585 $\mathrm{g}$ de $\mathrm{NaCl}$, $186 \mathrm{mg}$ de $\mathrm{KCl}, 10 \mathrm{~mL}$ de glicose $2 \mathrm{M}, \mathrm{H}_{2} \mathrm{O}$ Milli-Q estéril q.s.p. para $1 \mathrm{~L}$ ), em seguida, incubou-se as células em shaker a $37{ }^{\circ} \mathrm{C}$ por $1 \mathrm{~h}$ sob agitação de 300 rpm.

Sobre a superfície de cada placa contendo meio LB sólido (10 g/L triptona, 5,0 g/L extrato de levedura, $10 \mathrm{~g} / \mathrm{L} \mathrm{NaCl}, 7,5 \mathrm{~g} / \mathrm{L}$ ágar bacteriológico) acrescido de ampicilina $(100 \mu \mathrm{g} / \mathrm{mL})$ se espalhou previamente $100 \mu \mathrm{L}$ de IPTG (100 mM) e $20 \mu \mathrm{L}$ de X-Gal (50 mg/mL). Em seguida, foram colocados $100 \mu \mathrm{L}$ 
de cultura de células por placa e as mesmas foram incubadas em estufa a 37 ${ }^{\circ} \mathrm{C}$ durante $16 \mathrm{~h}$.

\subsubsection{Seleção e estoque de clones positivos}

A coloração branca das colônias foi o identificador dos clones transformantes. Esses clones foram coletados com palitos previamente esterilizados e transferidos para microplacas de 96 poços, contendo cada um $100 \mu \mathrm{L}$ de meio CG acrescido de ampicilina (50 $\mu \mathrm{g} / \mathrm{mL})$. A multiplicação dos clones foi realizada durante $22 \mathrm{~h}$, a $37^{\circ} \mathrm{C}$. Foi adicionado $100 \mu \mathrm{L}$ de glicerol $40 \%$ em cada poço para conservação das culturas permanentes e armazenadas em freezer $-80^{\circ} \mathrm{C}$. As culturas foram repicadas em placas ("Mega Titer") contendo $1 \mathrm{~mL}$ de meio CG acrescido de ampicilina (50 $\mu \mathrm{g} / \mathrm{mL})$. As microplacas foram seladas com filme adesivo, fazendo-se um furo no filme no limite de cada poço com agulha estéril para aeração da bactéria. $O$ crescimento dos clones foi realizado durante $22 \mathrm{~h}$ a $37^{\circ} \mathrm{C}$, com agitação de 300 rpm em shaker.

\subsubsection{Extração do DNA plasmidial}

Passado o período de crescimento dos clones, as microplacas foram centrifugadas durante $6 \mathrm{~min}$ a 1.238 x g para sedimentação das células. $\mathrm{O}$ sobrenadante foi descartado e as placas invertidas sobre o papel absorvente por 1 minuto. Em cada pocinho foi colocado $240 \mu \mathrm{L}$ de solução I-GTE (11,5 mL de glicose 20\%; 5,0 mL de 0,5M EDTA pH 8.0; 6,5 mL de Tris $\mathrm{pH} 7.4 ; 250 \mathrm{~mL}$ de água Milli-Q autoclavada), as placas foram seladas com filme adesivo e agitadas no vortex durante 2 min, após o qual foram centrifugadas por 6 minutos a $1.238 \times \mathrm{g}$. Simultaneamente à etapa de centrifugação, $2,5 \mu \mathrm{L}$ de RNAse $(10 \mathrm{mg} / \mathrm{mL})$ foram adicionados em microplacas de $250 \mu \mathrm{L}$ de 
polipropileno (tipo ELISA) com fundo em "U". O sobrenadante foi descartado e adicionado a cada pocinho $80 \mu \mathrm{L}$ de GTE, a placa foi selada e agitada no "vortex" durante 2 minutos, transferindo-se $80 \mu \mathrm{L}$ de cada suspensão de células para as microplacas citadas acima. Em seguida, colocou-se em cada pocinho $80 \mu \mathrm{L}$ de solução II - NaOH/SDS (2,5 mL de $4 \mathrm{M} \mathrm{NaOH}, 5 \mathrm{~mL}$ de SDS $10 \%, 50$ $\mathrm{mL}$ de água Milli-Q autoclavada). Após selar a placa, esta foi misturada 10 vezes por inversão, centrifugada por alguns segundos e incubada por $10 \mathrm{~min}$ à temperatura ambiente. Oitenta $\mu \mathrm{L}$ de solução III, contendo $60 \mathrm{~mL}$ de acetato de potássio $5 \mathrm{M} ; 28,5 \mathrm{~mL}$ de água; $11,5 \mathrm{~mL}$ de ácido acético glacial foram adicionados a cada pocinho. Selou-se a placa com adesivo, agitou-se por inversão por 10 vezes, centrifugando-a em seguida por alguns segundos e incubando-a por $10 \mathrm{~min}$ à temperatura ambiente. Ao final desta etapa, o adesivo foi removido e a placa foi incubada em estufa a $90^{\circ} \mathrm{C}$ por exatos $30 \mathrm{~min}$. Em seguida a placa foi esfriada em gelo por 10 min e centrifugada por 4 min a 1.238 x g. Uma placa "Millipore" (MAGV N220) foi acoplada no topo de uma outra microplaca de $250 \mu \mathrm{L}$ com fundo em "V", tendo o cuidado de observar o alinhamento entre as duas placas. Todo o volume obtido anteriormente (cerca de $110 \mu \mathrm{L}$ ) foi transferido para a placa "Millipore", a qual foi centrifugada por 4 min, $1.238 \times$ g, a $20^{\circ} \mathrm{C}$. Após remover e descartar a placa "Millipore" $110 \mu \mathrm{L}$ de isopropanol foi adicionado ao filtrado. A placa foi selada com adesivo, misturada 10 vezes por inversão e centrifugada a $1.238 \times \mathrm{g}$ durante $45 \mathrm{~min}$, a $20^{\circ} \mathrm{C}$. Após descartar o sobrenadante, foi adicionado $200 \mu \mathrm{L}$ de etanol $70 \%$ gelado. A placa foi centrifugada $5 \mathrm{~min}$, o sobrenadante foi descartado e a placa foi invertida sobre papel absorvente. A placa foi novamente centrifugada invertida sobre papel absorvente por alguns segundos a $500 \times \mathrm{g}$ e seca por 1 hora à temperatura ambiente. O DNA foi ressuspendido com $40 \mu \mathrm{L}$ de água Milli- $Q$ autoclavada durante a noite. A concentração do DNA foi avaliada em gel de agarose $1 \%$. 


\subsubsection{Reação de sequenciamento}

As reações de sequenciamento foram feitas de acordo com as instruções da Perkin Elmer para o "DNA Sequencing Kit Big Dye Terminator cycle sequencing ready reaction", $\vee$ 3.0. Para a reação foram utilizados aproximadamente $600 \mathrm{ng}$ de DNA. Foram adicionados $2 \mu \mathrm{L}$ do Mix Read Reaction e 0,5 $\mu \mathrm{L}$ do "primer" - T7Forward na concentração final de 5 pmols, 2 $\mu \mathrm{L}$ do tampão "Save Money" (400 mM Tris- $\mathrm{HCl} \mathrm{pH}$ 9,0, $10 \mathrm{mM} \mathrm{MgCl}_{2}$ ), completando o volume final para $10 \mu \mathrm{L}$ com água Milli-Q estéril. A reação foi misturada e centrifugada por alguns segundos antes de ser submetida ao aparelho termociclador (PERKIN ELMER - Gene AMP PCR System 9600). O programa utilizado no termociclador consistiu de 1 ciclo a $96{ }^{\circ} \mathrm{C}$ por $2 \mathrm{~min}, 25$ ciclos de $96{ }^{\circ} \mathrm{C}$ por 45 segundos, $50{ }^{\circ} \mathrm{C}$ por 30 segundos e $60^{\circ} \mathrm{C}$ por 4 min e um ciclo final de $4^{\circ} \mathrm{C}$.

A reação de sequenciamento foi precipitada adicionando $80 \mu \mathrm{L}$ de isopropanol $65 \%$ à placa e incubando-a a temperatura ambiente por 15 min. Houve uma centrifugação por 45 min a 1.258 x g. Descatou-se o sobrenadante e adicionou-se $200 \mu \mathrm{L}$ de etanol $70 \%$, realizando outra centrifugação a $1.258 \mathrm{x}$ g por 10 min. Repetiu-se a lavagem do produto das reações com etanol $70 \%$. 0 "pellet" secou durante $1 \mathrm{~h}$ em temperatura ambiente. O sequenciamento foi realizado no Sequenciador automático $A B I 3700$ - Perkin Elmer.

\subsubsection{Anotação das seqüências das bibliotecas construídas}

Os programas Sequencing Analysis da Perkin Elmer, Seq Man LASERGENE 99 (DNASTAR Inc.) foram usados para analisar as seqüências obtidas e a qualidade das seqüências geradas foi verificada através dos eletroesferogramas analisados pelo programa "Phred-Phap-Consed", empregando-se como critério de classificação pelo menos 300 bases por 
seqüência com qualidade acima de 20. Para verificação do alinhamento das seqüências foi utilizado o programa "CAP 3". As regiões correspondentes aos adaptadores e aos vetores empregados na clonagem foram removidas das seqüências. Através do alinhamento das seqüências, produziram-se "contigs" com suas respectivas seqüências consensos, as quais foram submetidas à consulta de similaridade com outras seqüências já depositadas no banco de dados GenBank acessado pelo NCBI (National Center for Biotechnology Information) através do endereço http//www.ncbi.nlm.nih.gov. As ferramentas utilizadas para esta consulta foram BLASTn e BLASTx, sendo que foram considerados apenas alinhamentos entre seqüências nucleotídicas e protéicas que obtiveram "e-value" inferior a $10^{-3}$.

\subsubsection{Hibridizações}

Após a análise das seqüências no banco de dados, os clones que apresentaram seqüências altamente similares a seqüências de vírus foram marcados por quimioluminescência e utilizados como controles. Os clones selecionados a partir da biblioteca de cDNA foram:

- 01E04, 01A09 e 01E12. Estes clones são da região genômica que provavelmente codifica a proteína replicase (rep);

- 03G02, 03A04 e 02F07. Estes clones são da região genômica que provavelmente codifica a proteína de movimento $(\mathrm{mp})$.

A marcação foi realizada por PCR que além de 3,0 $\mu \mathrm{L}$ de DNA dos clones, utilizou 1,0 $\mu \mathrm{L}$ dNTP (mix) marcado com digoxigenina do Kit DIG DNA Labeling Kit (Roche Molecular Biochemicals), 2,5 $\mu \mathrm{L}$ do tampão 10x, 1,25 $\mu \mathrm{L}$ de $\mathrm{MgCl}_{2} 50 \mathrm{mM}, 2,0 \mu \mathrm{L}$ de cada "primer" utilizado foward (T7) ou reverse (SP6) a $50 \mathrm{ng} / \mu \mathrm{L}, 0,25 \mu \mathrm{L}$ da enzima Taq DNA polimerase (Invitrogen) $5 \mathrm{U} / \mathrm{mL}$ e $\mathrm{H}_{2} \mathrm{O}$ estéril para $25 \mu \mathrm{L}$ de volume final. Os ciclos usados no termociclador foram: 1 ciclo a $94^{\circ} \mathrm{C}$ por $3 \mathrm{~min}, 35$ ciclos de $94^{\circ} \mathrm{C}$ por $1 \mathrm{~min}, 50^{\circ} \mathrm{C}$ por 1 min e $72{ }^{\circ} \mathrm{C}$ 
por $1 \mathrm{~min}$ e um ciclo final de $72{ }^{\circ} \mathrm{C}$ durante $10 \mathrm{~min}$. Os produtos das reações de amplificação foram visualizados em gel de agarose 1,0\% contendo brometo de etídio.

Foram colocados em membrana de Nylon (Hybond N - Amersham) $2 \mu \mathrm{L}$ do DNA do clone (controle) apresentando seqüência com alto índice de homologia a seqüências de vírus (o mesmo utilizado para marcação da sonda). Esse clone foi previamente desnaturado a $75{ }^{\circ} \mathrm{C}$ por 10 minutos. Também na membrana foram colocadas amostras de dsRNA e sSRNA do SvRSV obtidos de plantas de datura sintomáticas e sadias, Além de amostras de ssRNA total de plantas de laranjeira sintomáticas para leprose previamente desnaturadas com um volume de solução desnaturante (SPE 20X:Formaldeído (60:40)). A metodologia foi seguida segundo Sambrook et al. (1989) e de acordo com especificações do manual do kit utilizado para marcação das sondas.

\subsubsection{Pré-hibridização}

Após a aplicação das amostras diretamente nas membranas as membranas foram fixadas em UV $(120 \mathrm{~mJ})$ e em seguida incubadas em uma quantidade de solução proporcional ao tamanho das mesmas $\left(0,2 \mathrm{~mL} / \mathrm{cm}^{2}\right)$. A solução de pré hibridização consistiu de $5 \mathrm{~mL}$ de formamida deionizada, $1 \mathrm{~mL}$ de SDS 5\%, $3 \mathrm{~mL}$ de tampão SSPE 20X, $1 \mathrm{~mL}$ de solução Denhardt (5 g Ficoll, $5 \mathrm{~g}$ de PVP, $5 \mathrm{~g}$ BSA e $\mathrm{H}_{2} \mathrm{O}$ para $500 \mathrm{~mL}$ ). Utilizou-se o DNA de esperma de salmão (10 $\mu \mathrm{L}$ de uma solução de $10 \mathrm{mg} / \mathrm{mL}$, para cada $\mathrm{mL}$ de tampão utilizado) desnaturado em banho fervente por 10 min e colocado imediatamente no tampão de hibridização. A pré-hibridização foi feita a $50{ }^{\circ} \mathrm{C}$ durante $2 \mathrm{~h}$.

\subsubsection{Hibridização}

A composição da solução de hibridização foi de $5 \mathrm{~mL}$ de formamida deionizada, $1 \mathrm{~mL}$ de SDS 5\%, $3 \mathrm{~mL}$ de tampão SSPE 20X, $1 \mathrm{~mL}$ de $\mathrm{H}_{2} \mathrm{O}$. O 
DNA de esperma de salmão e a sonda $\left(20 \mathrm{ng} / \mathrm{cm}^{2}\right)$ foram desnaturados em banho fervente durante $10 \mathrm{~min}$ e, em seguida, adicionados à solução de hibridização. A hibridização foi feita durante a noite a $50^{\circ} \mathrm{C}$.

\subsubsection{Lavagens, Detecção e Revelação}

A solução de hibridização foi descartada e foram feitas duas lavagens com $10 \mathrm{~mL}$ de solução I ( 2 X SSC; $0,1 \%$ SDS) durante 15 min à temperatura ambiente. Em seguida, foi feita uma lavagem com $10 \mathrm{~mL}$ de solução II $(0,1 \mathrm{X}$ SSC; $0,1 \%$ SDS) durante 1 hora a $60^{\circ} \mathrm{C}$.

Todo processo de detecção foi feito à temperatura ambiente. A solução de lavagem foi descartada e foram adicionados $10 \mathrm{~mL}$ de tampão 1 (0,1 M de ácido maleico; 0,15 M NaCl, $\mathrm{pH} 7,5$ ) contendo 0,3\% Tween 20. Foi feita uma incubação durante $5 \mathrm{~min}$. Em seguida, foram adicionados $10 \mathrm{~mL}$ de tampão 2 (1\% bloqueador do Kit de detecção da Roche Molecular Biochemicals em tampão 1) e foi feita uma incubação durante $30 \mathrm{~min}$. O tampão foi descartado, foram adicionados $5 \mathrm{~mL}$ de tampão 2 contendo o anti-digoxigenina-AP conjugado a uma diluição de 1:5000, e foi feita nova incubação por 30 min. As membranas foram lavadas duas vezes com $10 \mathrm{~mL}$ de tampão 1 durante $15 \mathrm{~min}$. Em seguida, foram adicionados $10 \mathrm{~mL}$ de tampão $3(0,1 \mathrm{M}$ Tris- $\mathrm{HCl} ; 0,1 \mathrm{M}$ $\mathrm{NaCl} ; 50$ mM MgCl ; pH 9,5) e foi feita uma incubação durante 30 min. Foram adicionados $5 \mathrm{~mL}$ de tampão 3 contendo CSPD a uma diluição de 1:200 e foi feita uma incubação durante $5 \mathrm{~min}$. O excesso de tampão foi retirado e as membranas colocadas entre 2 folhas de plástico e expostas a filme de raio $X$. $O$ cassete foi incubado a $37^{\circ} \mathrm{C}$ durante 1 a $30 \mathrm{~min}$ e em seguida o filme foi revelado.

Para revelação foram usados filmes de raio-X HYPERfilme-MPAmersham.

As membranas foram reveladas por 2 min em solução de revelação (Kodak GBX - developer and replenesher), lavadas durante 30 segundos em 
$\mathrm{H}_{2} \mathrm{O}$, fixadas por 1 minuto em solução de fixação (Kodak GBX - fixer and replenesher) e analisadas após a secagem.

\subsubsection{Síntese de iniciadores (primers) e RT-PCR para detecção}

Foram desenhados "primers" com o objetivo de amplificar as regiões genômicas específicas do vírus que aparentemente representam genes que codificam putativamente as proteínas de movimento e replicase viral. Os "primers" foram desenhados usando os programas "Primers Select LASERGENE 99 (DNASTAR Inc.) e "Primer 3" - acessado pelo endereço http://frodo.wi.mit.edu/cgi-bin/primer3/primer3_www.cgi.

Os pares de "primers" FORWARDSEQ1 5'TGTCGAACTTTGGTATGAGTCG-3' (F1), REVERSESEQ2 5'CCGGTTCGTCAAATAACTCC-3' (R2), FORWARDSEQ3 5'ATGACCGAACATCACGATCC-3' (F3), REVERSESEQ4 5'GAACGTCCCTCCGTCACC-3' (R4), FORWARDSEQ5 5'TGGTATGAGTCGCATGTTGA-3' (F5), REVERSESEQ6 5'TGTCCTGAACAGGGATCAAA-3' (R6) foram obtidos e usados para amplificar regiões genômicas do SvRSV com fragmentos entre aproximadamente 250 e $600 \mathrm{pb}$ do gene que codifica a provável replicase.

Já o par de "primers" FORWARDSEQ7 5'CAACATCCACCAAAATCGAC-3' (F7) e REVERSESEQ8 5'GTGCGAATTGGAATCTTTGC-3' (R8) foram desenhados e utilizados para amplificar uma região que codifica a possível proteína de movimento. Estes iniciadores amplificam fragmentos de DNA de aproximadamente $530 \mathrm{pb}$.

Para avaliação dos primers e diagnose do SvRSV foi feito RT-PCR com amostras de Ligustrum sp. (ligustre) e S. violaefolium (solano-violeta) infectados com o vírus da mancha verde de ligustro, Salvia leucantha (sálvia-branca), Hibiscus cannabinus (kenaf), Cestrum nocturnum (dama-da-noite) infectados com o vírus da mancha clorótica de Clerodendron (CICSV), orquídea (contendo 
OFV do tipo citoplasmático e nuclear) e Citrus spp (citros) infectada com o CiLV-C. Neste conjunto de amostra ainda tinha planta de solano-violeta infectada com o SvRSV. As amostras de orquídea e de citros são provenientes do banco de amostra do Centro APTA Citros "Sylvio Moreira". Também foi utilizado o controle sadio para cada amostra.

O cDNA das amostras foi feito utilizando o 2,5 $\mu \mathrm{L}$ de RNA total (ítem 4.6.2.3), $1 \mu \mathrm{L}$ de dNTP, 0,5 $\mu \mathrm{L}$ de GDP (Genome-Directed Primers) e 8,5 $\mu \mathrm{L}$ de água Milli-Q. A reação foi incubada a $95^{\circ} \mathrm{C}$ por 5 min e colocada em seguida no gelo. Em seguida foi adicionado a esta reação $5 \mu \mathrm{L}$ de tampão $5 X$ PCR (Invitrogen), $2 \mu \mathrm{L}$ de DTT, 0,5 $\mu \mathrm{L}$ de RNAse-out e $1 \mu \mathrm{L}$ da enzima M-MLV-RT (Invitrogen). A reação foi encubada a $37^{\circ} \mathrm{C}$ por $70 \mathrm{~min}$. Em microtubos de 0,2 $\mathrm{mL}$ foram feitas as reações contendo $2,5 \mu \mathrm{L}$ de cDNA das plantas acima. Cada reação continha 2,5 $\mu \mathrm{L}$ de tampão PCR 10X (Invitrogen), 0,9 $\mu \mathrm{L}$ de $\mathrm{MgCl}_{2}, 0,5$ $\mu \mathrm{L}$ dNTP 2,5 mM, 0,5 $\mu \mathrm{L}$ de cada iniciador (200 $\mathrm{ng} / \mu \mathrm{L}), 0,2 \mu \mathrm{L}$ da enzima TaqDNA Polimerase e água Milli-Q estéril para um volume final de $25 \mu \mathrm{L}$. O programa de temociclagem constava de 1 ciclo de $94{ }^{\circ} \mathrm{C}$ por 2 minutos, 33 repetições de $94{ }^{\circ} \mathrm{C}$ por 30 segundos, $58^{\circ} \mathrm{C}$ por 40 segundos e $72{ }^{\circ} \mathrm{C}$ por 40 segundos, 1 ciclo de $72{ }^{\circ} \mathrm{C}$ por 10 minutos. Os resultados das amplificações foram avaliados por meio de eletroforese em gel de agarose $1 \%$. 


\section{RESULTADOS E DISCUSSÃO}

\subsection{Ensaios de transmissão}

Após a inoculação mecânica do vírus da mancha anelar do $S$. violaefolium, as plantas ficaram em casa-de-vegetação durante três semanas, nas quais foram feitas observações diárias e constatado ou não o aparecimento de sintomas do vírus. A relação completa da plantas inoculadas, bem como a presença ou não de sintomas estão listadas na tabela 3.

Entre as 38 plantas utilizadas nos ensaios de transmissão, 14 plantas testes mostraram sintomas de mancha verde/clorótica quando inoculadas mecanicamente com o SvRSV. Partículas virais foram observada em oito plantas testes quando o vírus foi transmitido por meio do ácaro vetor. Em plantas como, pimentão, D. suaveolens, D. stramonium, kenaf, $N$. clevelandii, $N$. tabacum e solano-violeta, os sintomas apareceram tanto em inoculação mecânica quanto em inoculação por meio do ácaro vetor. Entretanto, em algumas plantas se observou apenas o aparecimento de sintomas quando inoculadas mecanicamente, como por exemplo, C. quinoa, C. amaranticolor, G. globosa, tomate, $N$. benthamiana, $N$. glutinosa e $N$. rústica. Nenhum ácaro foi encontrado nestas plantas durante o período de alimentação para inoculação, o que sugere um efeito antagonista destas plantas no vetor. Lovisolo et al. (2000) também não obtiveram sucesso em transmitir o CiLV com ácaros virulíferos para Amaranthaceae e Chenopodiaceae. Em plantas de manto-do-rei, era de se esperar que, com a inoculação mecânica, a planta mostrasse sintomas, visto que a planta parece ser hospedeira do vírus, pois a transmissão por meio do ácaro vetor foi positiva. Entretanto isto não foi observado nos experimentos. 
Tabela 3. Reação das plantas inoculadas com SvRSV mecanicamente e via ácaro $B$. phoenicis

\begin{tabular}{lll}
\hline Planta teste & & Sintomas \\
\hline Capsicum annuum & Inoculação mecânica & Transmissão por ácaro \\
Chenopodium amaranticolor & Mancha clorótica & Mancha clorótica \\
C. quinoa & Mancha clorótica & Sem sintomas \\
Datura stramonium & Mancha clorótica & Sem sintomas \\
D. suaveolens & Mancha clorótica & Mancha necrótica \\
Gomphrena globosa & Mancha clorótica & Sem sintomas \\
Hibiscus cannabinus & Mancha verde & Mancha verde \\
Lycopersicum esculentum & Mancha clorótica & Sem sintomas \\
Nicotiana benthamiana & Mancha clorótica & Sem sintomas \\
N. clevelandii & Mancha clorótica & Mancha clorótica \\
N. glutinosa & Mancha clorótica & Sem sintomas \\
N. rustica & Mancha clorótica & Sem sintomas \\
N. tabacum & Mancha clorótica & Mancha clorótica \\
Solanum violaefolium & Manchas clorótica & Mancha clorótica \\
Thunbergia erecta & Sem sintomas & Mancha clorótica \\
& & Manch
\end{tabular}

Os sintomas apresentados na maioria das plantas testes, inoculadas mecanicamente, se caracterizaram por pontos cloróticos, podendo evoluir para necrose, também se observou manchas cloróticas e necróticas, bem como mancha verde em folhas senescentes (Figura 4).

Quando o vírus foi transmitido por meio do ácaro Brevipalpus, os sintomas, em geral, são caracterizados por apresentarem pontos necróticos e manchas anelares, mancha clorótica em folhas verdes e mancha verde em folha senescente (Figura 5). 


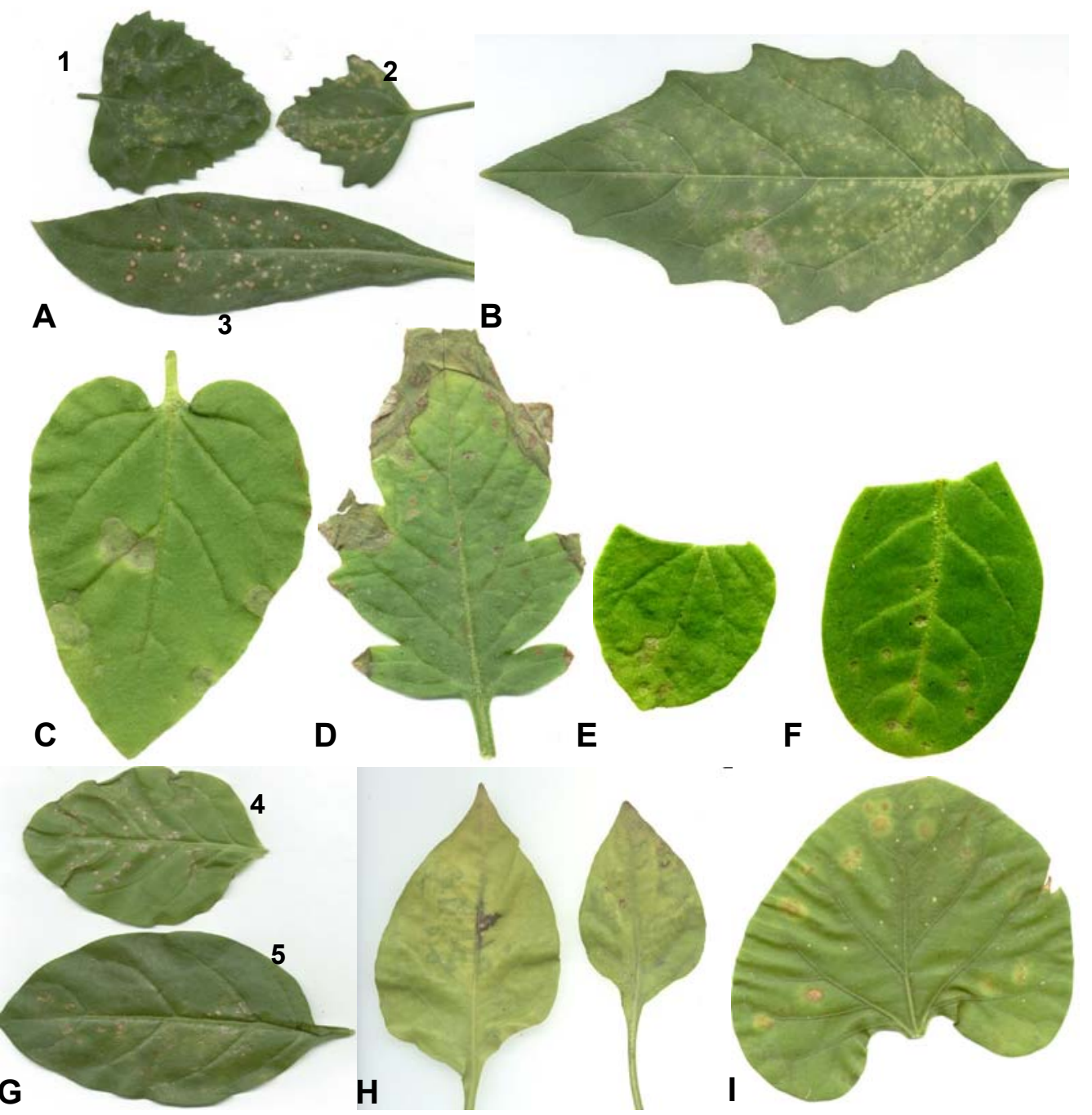

Figura 4 - Sintomas do SvRVS transmitido por inoculação mecânica. (A) Chenopodium amaranticolor - 1, C. quinoa -2 e Gomphrena globosa 3, (B) Datura stramonium, (C) Nicotiana glutinosa, (D) Lycopersicum esculentum, (E) N. benthamiana, (F) N. clevelandii, (G) N. tabaccum - 4 e N. rustica - 5, (H) Capsicum annum - 6 e 7, e (I) Solanum violaefolium 


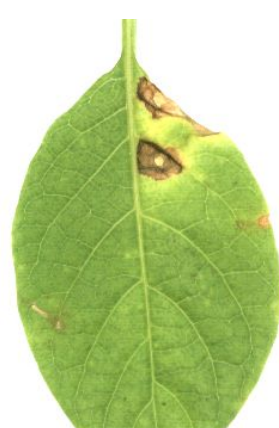

A

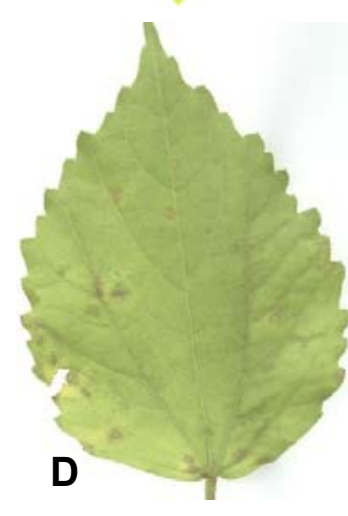

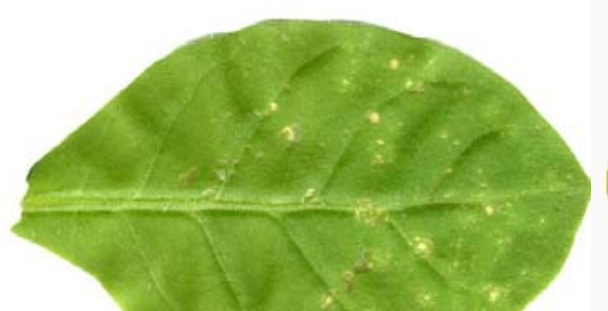

B

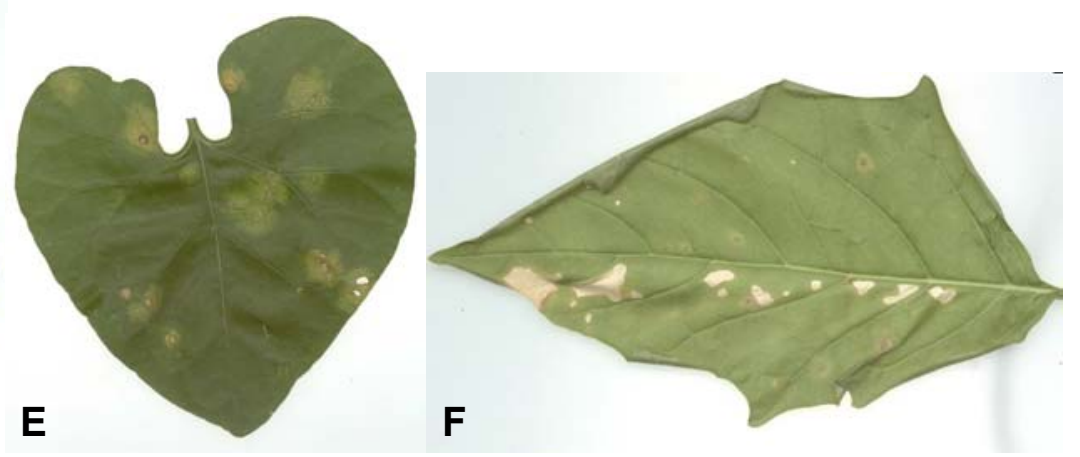

Figura 5 - Sintomas do SvRVS transmitido por Brevipalpus phoenicis. (A) Datura soavelum, (B) Nicotiana tabacum (samsun), (C, D) Hibiscus cannabinus, (E) Solanum violaefolium, (F) Datura stramonium

Análises de secções ultrafinas de plantas S. violaefolium coletadas próximos a plantas de ligustro, mostrou que o vírus da mancha verde de ligustro também pode infectar $S$. violaefolium.

Em análises morfo-anatômicas de folhas de $S$. violaefolium, observaram-se alterações nas células da epiderme, do parênquima lacunoso (pl) e do parênquima paliçádico (pp), nos tecidos infectados quando comparados com tecidos de folhas sadias (Figura 6A). Em algumas células da epiderme e do parênquima lacunoso pode se observar células hipertrofiadas (Figura 6B), além disso, pode ocorrer também hiperplasia nas células e algumas delas podem sofrer lise e alterações nos cloroplastos (Dados não mostrados). 

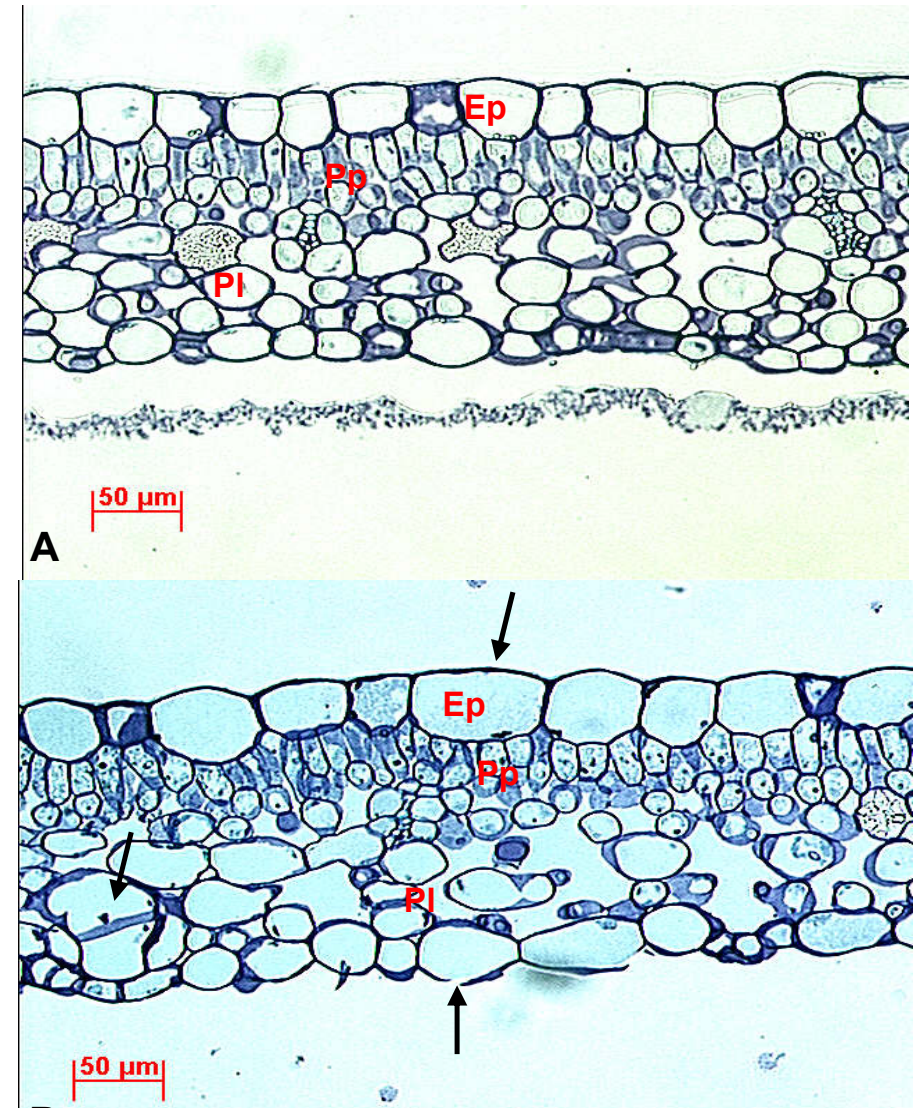

B

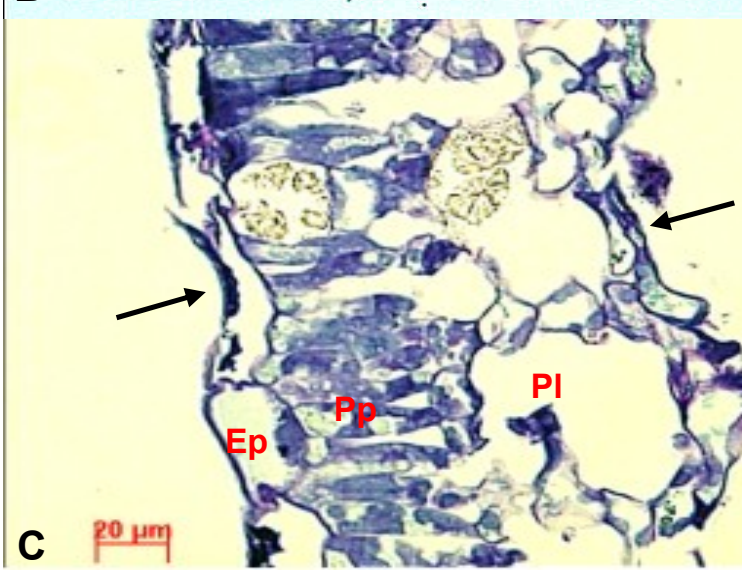

Figura 6 - Secções transversais da lâmina foliar de Solanum violaefolium. A Tecido sadio. B e C - Tecido infectado com SvRVS. Em B, nota-se células hipertrofiadas na epiderme e parênquima lacunoso (ponta da seta). A seta indica célula da epiderme necrosada em C. Pp Parênquima paliçádico, PI - Parênquima lacunoso, Ep - Epiderme 
Em lesão necrótica há necrose localizada de células, ocasionando o colapso da epiderme (Figura $6 \mathrm{C}$ ). Essas alterações são responsáveis pela externalização dos sintomas de manchas cloróticas e necrose.

\subsection{Microscopia eletrônica de transmissão}

Todas as tentativas de se visualizar as partículas baciliformes do SvRSV em suspensão foram infrutíferas, tanto em extratos ("leaf dip") como em preparações purificadas. Possivelmente os métodos empregados não logram preservar a estrutura tridimensional das partículas. Os ensaios de longevidade in vitro revelam que a infectividade permanece ativa por vários dias. Assim é provável que mesmo sem a intregridade física das partículas a infectividade, na forma de nucleocapsídeo, sem a membrana, seria preservada.

Em secções das lesões, tanto na hospedeira original, S. violaefolium, como nas das hospedeiras para as quais o vírus foi transmitido mecanicamente ou por meio de ácaros virulíferos, observaram-se efeitos citopáticos essencialmente similares. Numerosas partículas baciliformes de cerca de 50-60 $\mathrm{nm}$ em diâmetro, mais delgados que os rhabdovirus, avaliados em secções transversais, e de comprimento variável, de cerca de $100 \mathrm{~nm}$ a quase $1 \mu \mathrm{m}$ (Figura 7 e $8 \mathrm{H}$ ), foram notadas sempre no lúmen de cavidades limitadas por membrana única, derivadas do retículo endoplasmático. As partículas claramente possuem uma membrana envoltória. Esta variabilidade no comprimento faz SvRSV diferir de outros vírus do tipo citoplasmático transmitidos pelo Brevipalpus, que tendem a ter comprimento mais homogêneo, em torno de 110 - $120 \mathrm{~nm}$. Além das partículas, constatou-se a presença de massas elétron-densas e vacuoladas, sem membrana envoltória, no citoplasma, interpretada como viroplasma (sítio de acúmulo de material precursor dos virions onde ocorreria a síntese e/ou a montagem das partículas). Usualmente, 
observou-se apenas um viroplasma de dimensões avantajadas (vários $\mu \mathrm{m}$ de extensão), freqüentemente próximo ao núcleo, embora, ocasionalmente, podese notar a ocorrência de vários viroplasmas menores. A forma variava de elipsóide a irregular com saliências e reentrâncias. Em algumas secções favoráveis, em cavidades contendo virions, situadas junto ao viroplasma, podese notar o que parece se fases intermediárias de morfogênese das partículas virais por "brotação" (Figura 7). Membrana da partícula viral apresenta continuidade com a membrana da cavidade. Este fato também é considerado como evidência de que o material que compõe o viroplasma seria precursor dos vírions. Como no caso de outros vírus provido e membrana, as glicoproteínas codificadas pelo vírus e inseridas nas membranas devem estar envolvidas neste processo de morfogênese.

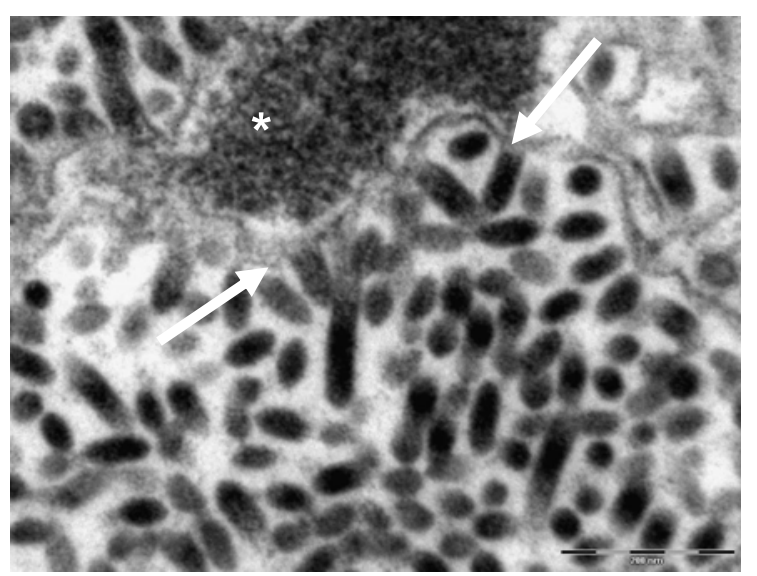

Figura 7 - Micrografia de seções ultrafinas de tecidos Thunbergia sp. com lesões com sintomas do SvRVS. A seta mostra provável morfogênese das partículas. * Viroplasma

Partículas baciliforme semelhantes à Rhabdovirus também foram observadas em cortes ultrafinos de amostras de tecidos de plantas infectadas experimentalmente apresentando lesões. Análises das secções ultrafinas mostraram efeito citopático tipo citoplasmático, com grupos de partículas 


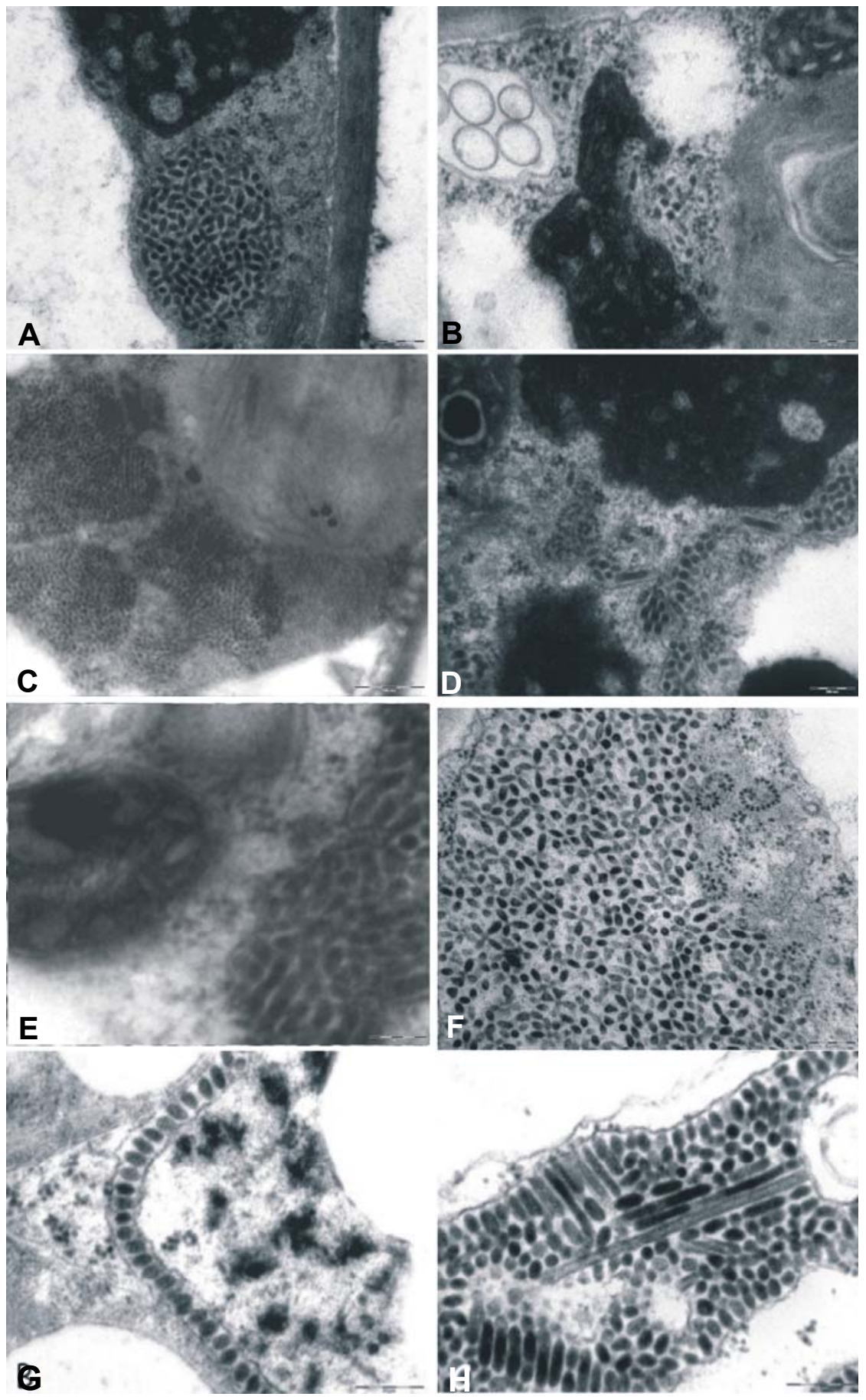

Figura 8 - Micrografia de seções ultrafinas de tecidos com lesões com sintomas do SvRVS. (A) Datura soavelum; (B) Salvia leucantha; (C) Datura stramonium; (D) Solanum violaefolium; (E) Gomphrena globosa; (F) Capsicum annum; (G e H) Hibiscus cannabinus 
baciliforme no lúmen do retículo endoplasmático e um viroplasma eletron denso no citoplasma (Figura 8A - H).

A ligeira, mas consistente, diferença na morfologia das partículas do SvRSV em secções quando comparado com outros vírus do tipo citoplasmático transmitido por ácaros Brevipalpus sugere que talvez ele represente um subtipo deste grupo.

\subsection{Morfologia externa do Brevipalpus spp.}

Nas primeiras coletas em folhas de $S$. violaefolium e montagens dos ácaros para visualização ao microscópio eletrônico, apenas $B$. phoenicis foi encontrado nesta hospedeira. Em cada análise de material feita (cerca de 10 ácaros por vez), nenhuma outra espécie deste ácaro foi constatada. Resultados coerentes com as literaturas que cita que este ácaro é mais prevalente que as demais espécies (Childers et al., 2003). Isto pode ser devido, em parte, pela grande capacidade de colonizar de modo eficiente um número amplo de hospedeiras.

Entretanto, nas últimas coletas de material para análise, a ocorrência de $B$. obovatus foi constatada com maior freqüência nas plantas de $S$. violaefolium. Não se tem uma explicação clara para este aumento das observações de $B$. obovatus, já que em experimentos preliminares, nas mesmas hospedeiras, apenas $B$. phoenicis era encontrado. A transferência destes ácaros para plantas de solano-violeta e datura provocou sintomas de lesão clorótica e necrótica. $E$ análise ao microscópio eletrônico de transmissão de tecido de folhas infectadas mostraram partículas baciloformes semelhante às partículas encontradas nas plantas com SvRSV. Se isto for confirmado, trata-se do segundo caso de transmissão de vírus por $B$. obovatus no Brasil, após a verificação disto com o vírus da mancha anular da dama-da-noite (Freitas-Astua et al., 2002). Por outro 
lado, as tentativas de transmissão de CiLV-C pelo $B$. obovatus no Brasil não tiveram sucesso (Rodrigues, J.C.V, comunicação pessoal).
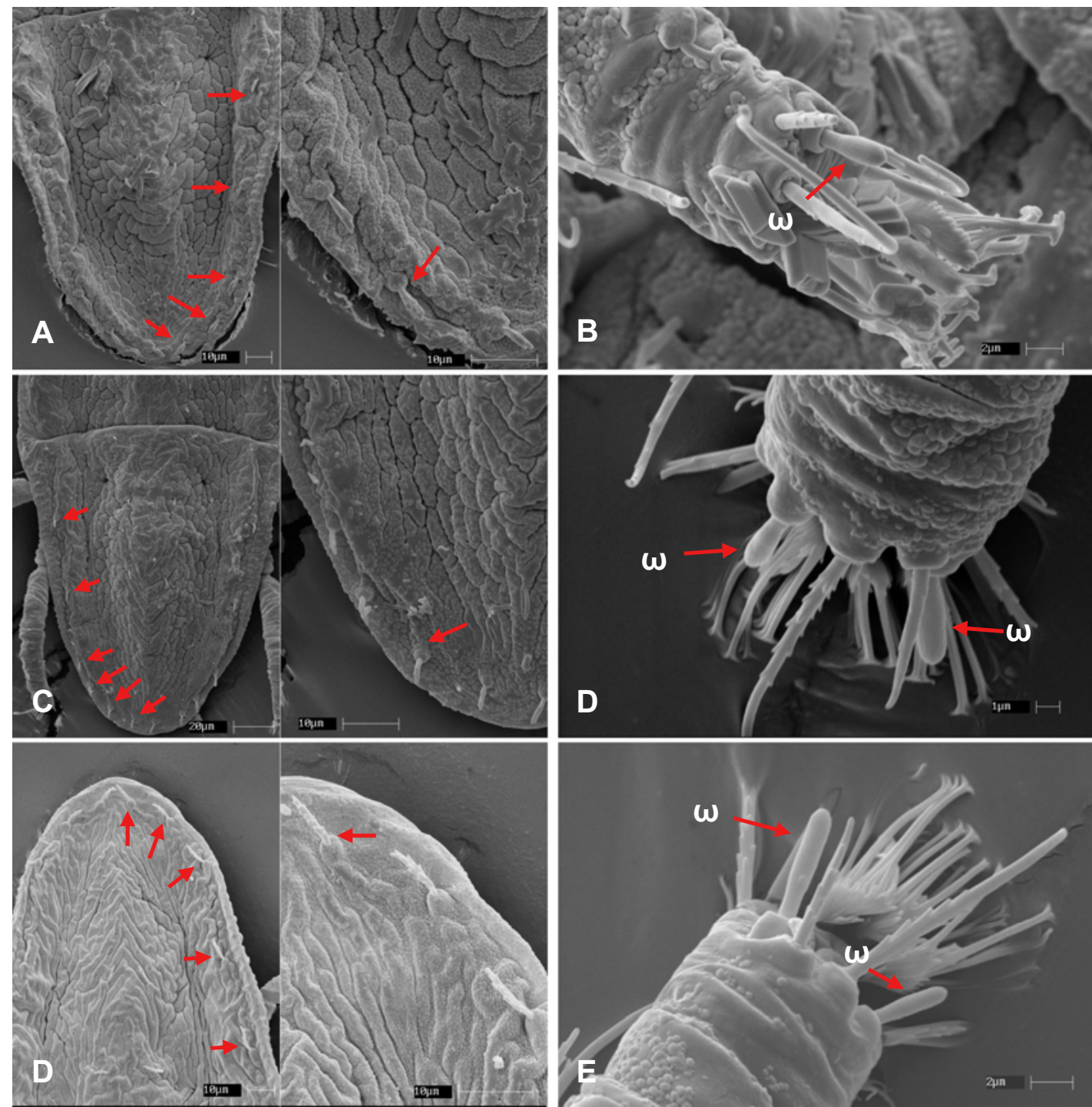

Figura 9 - Comparação morfológica dos ácaros Brevipalpus obovatus (A e B), B. phoenicis (C e D) e B. californicus (E e F). Número de setas dorsais $(A, C$ e $E)$ e solenídios $(\omega)(B, D$ e $F)$ 


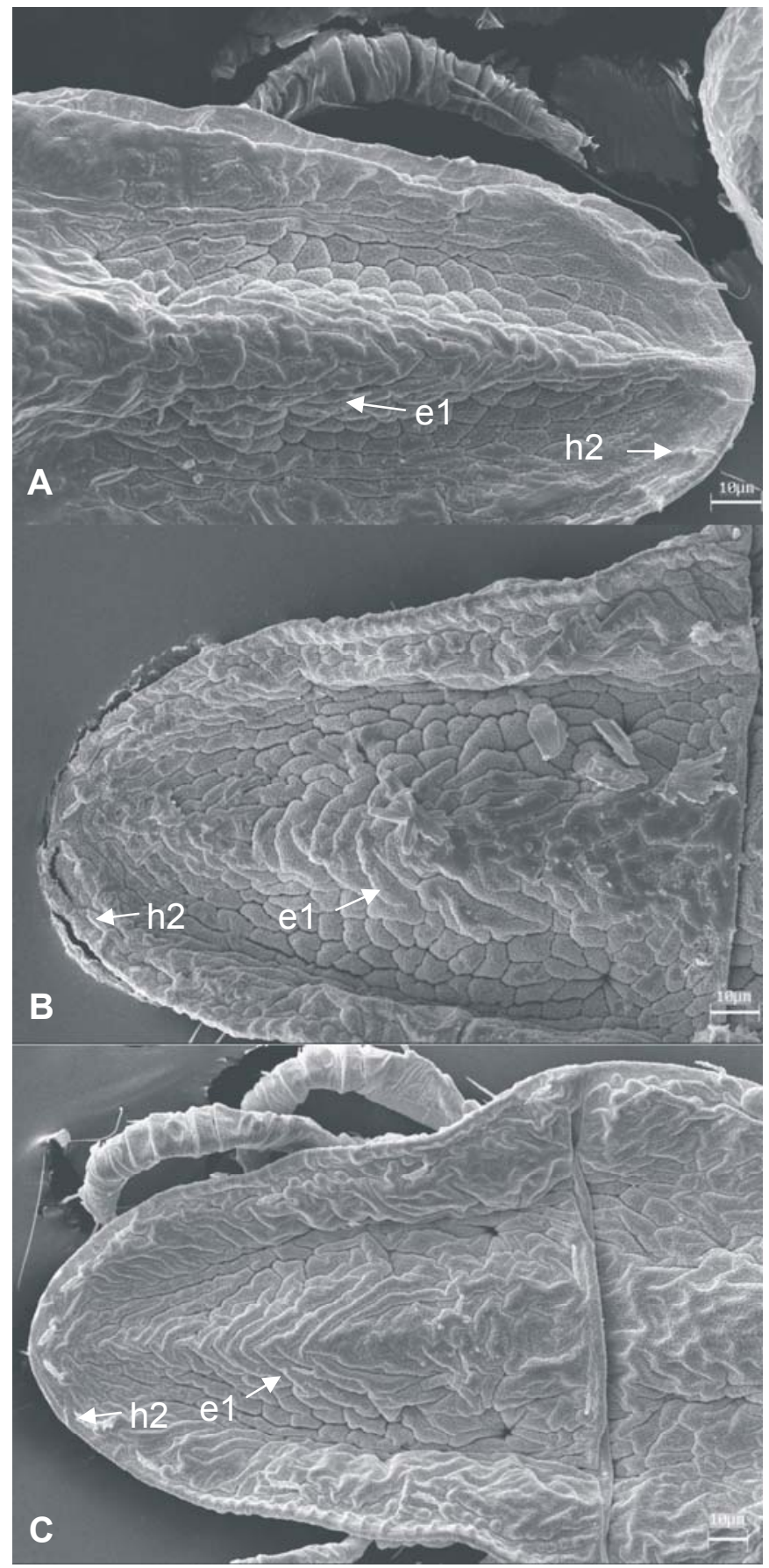

Figura 10 - Comparação morfológica da área central entre os pares de seta e1 e h2 dos ácaros B. californicus (a) , B. obovatus (b) e B. phoenicis (c). B. californicus irregular, $B$ obovatus em forma de $U$ e $B$. phoenicis em forma de $\mathrm{V}$ 
Em nenhum instante $B$. californicus foi encontrado, ocorrendo isto apenas em plantas de orquídeas. As principais diferenças entre estas três espécies está no número de setas dorsais (5 em $B$. phoenicis e em $B$. obovatos e 6 em $B$. californicus) e no número de solenídeos (seta ômega) no tarso da perna 2 (1 em $B$. obovatus e 2 em $B$. phoenicis e B. californicus), como pode ser observado na Figura 9. No opistossoma, a área central entre os pares de setas e1 e h2 também apresenta diferenças. Em B. californicus, as reticulações são irregulares, em $B$. obovatus essas reticulações também são irregulares, mas em forma de $U$. Já em $B$. phoenicis essas reticulações apresenta de 6 a 8 sulcos em forma de $\mathrm{V}$ (Figura 10).

Observações sem auxílio de microscopia não permitem distinguir uma espécie da outra, o que torna laborioso a obtenção de colônias de uma única espécie, pois as análises microscópicas são destrutivas, não permitindo a recuperação das amostras análisadas.

Comparações morfológicas dos principais gêneros Brevipalpus podem ser observadas no trabalho realizado por Welbourn et al. (2003), onde os autores também estudaram outros caracteres que distinguem as três principais espécies.

\subsection{Determinação de propriedades físicas in vitro}

Após comprovação da transmissão mecânica do SvRSV, foi possível determinar a sua estabilidade in vitro, verificando-se até que ponto o mesmo poderia se manter ativo, isto é, com capacidade para induzir sintomas na espécie indicadora (D. stramonium) após os tratamentos do extrato foliar.

Os resultados das avaliações de estabilidade in vitro do SvRSV pode ser visto na tabela 4. 
Tabela 4. Resultados dos testes de estabilidade do Solanum violaefolium Ringspot Virus (SvRSV). Cada repetição é representada por 4 plantas

\begin{tabular}{|c|c|c|c|}
\hline \multirow{2}{*}{$\begin{array}{l}\text { Propriedades Físicas in vitro } \\
\text { Ponto de inativação térmica }\end{array}$} & \multicolumn{3}{|c|}{ Aparecimento de sintomas em Datura stramonium $^{a}$} \\
\hline & $1^{a}$ & 2 & 3 \\
\hline $4^{\circ} \mathrm{C}$ & $+^{a}$ & + & + \\
\hline $30^{\circ} \mathrm{C}$ & + & + & $n d^{b}$ \\
\hline $40^{\circ} \mathrm{C}$ & + & - & - \\
\hline $50^{\circ} \mathrm{C}$ & - & - & - \\
\hline $60^{\circ} \mathrm{C}$ & - & - & - \\
\hline $70^{\circ} \mathrm{C}$ & - & - & - \\
\hline \multicolumn{4}{|l|}{ Ponto final de diluição } \\
\hline $10^{-1}$ & $++^{b}$ & + & + \\
\hline $10^{-2}$ & + & + & + \\
\hline $10^{-3}$ & + & + & + \\
\hline $10^{-4}$ & - & - & - \\
\hline $10^{-5}$ & - & - & - \\
\hline $10^{-6}$ & - & - & - \\
\hline $10^{-7}$ & - & - & - \\
\hline \multicolumn{4}{|l|}{ Conservação in vitro } \\
\hline $1 \mathrm{dia}$ & + & + & $\mathrm{nd}^{\mathrm{c}}$ \\
\hline 02 dias & + & + & nd \\
\hline 03 dias & + & + & nd \\
\hline 04 dias & + & + & nd \\
\hline 05 dias & + & + & nd \\
\hline 06 dias & + & + & nd \\
\hline 07 dias & + & + & nd \\
\hline 08 dias & + & + & nd \\
\hline 09 dias & + & + & nd \\
\hline
\end{tabular}


Tabela 4. Resultados dos testes de estabilidade do Solanum violaefolium Ringspot Virus (SvRSV). Cada repetição é representada por 4 plantas

\begin{tabular}{cccc}
\hline Propriedades Físicas in vitro & Aparecimento de sintomas em Datura stramonium \\
\hline Conservação in vitro & & + & \\
10 dias & + & + & nd \\
11 dias & + & + & nd \\
12 dias & + & - & nd \\
13 dias & - & - & nd \\
14 dias & - & - & nd \\
15 dias & - & - & nd \\
16 dias & - & - & nd \\
17 dias & - & - & nd \\
18 dias & - & - & nd \\
19 dias & - & - & nd \\
20 dias & - & nd
\end{tabular}

(a) Foram 3 repetições em cada ensaio. (b) $\mathrm{O}$ sinal (+) corresponde à presença de sintomas e 0 sinal (-) corresponde à ausência. (c) nd - não determinado

(a) Ponto final de diluição do vírus

O ponto final de diluição do SvRSV foi determinado inoculando uma série de diluições em plantas de datura. Após essas inoculações, foi observado que apenas as frações diluídas até $10^{-3}$ foram capaz de induzir lesões em $D$. stramonium. Sendo assim, pode-se considerar que o ponto final de diluição do SvRSV está entre $10^{-3}$ e $10^{-4}$.

Lovisolo et al. (1996), trabalhando com a leprose dos citros, mostraram que inoculando o CiLV em plantas de C. quinoa, o ponto final de diluição foi de $10^{-3}$. Enquanto Chagas (1978b), obteve um ponto final de $10^{-4}$ para a mancha anelar do café inoculada também em C. quinoa. 
(b) Ponto de inativação térmica do vírus

Apenas as inoculações efetuadas com suco previamente submetido às temperaturas até $40^{\circ} \mathrm{C}$ conseguiram induzir sintomas em $D$. stramonium. Para a leprose dos citros, o ponto de inativação térmica ficou entre 55-60 $\mathrm{C}$ (Lovisolo et al., 1996). Já a mancha anelar do café apresentou uma inativação térmica em torno de $70^{\circ} \mathrm{C}$ (Chagas, 1978b).

(c) Conservação do vírus

Preparações de extrato da planta com o SvRSV foi conservado em frascos à temperatura ambiente e inoculadas em plantas de daturas. As observações do aparecimento de sintomas nas plantas inoculadas mostraram que o extrato da planta se manteve infectivo por 12 dias.

Usando tampão fosfato $(\mathrm{pH} 7,0)$ contendo Na-DIECA, EDTA e Tioglicolato, Lovisolo et al. (1996) conseguiram transmitir o CiLV após seis dias da extração da folha sintomática, conservando-o a $4{ }^{\circ} \mathrm{C}$. Já à temperatura ambiente, a infectividade se manteve por apenas três dias (Lovisolo et al., 2000). Chagas (1978b) mostrou que a infectividade do CoRSV se mantém por 19 dias à $4^{\circ} \mathrm{C}$.

Estes dados mostram que as propriedades in vitro do SvRSV parece ser bem distinta em relação à mancha anelar do cafeeiro (CoRSV), entretanto, os valores são próximos à leprose dos citros (CiLV).

\subsection{Purificação}

Nos testes de transmissão, constatou-se que $D$. stramonium é uma boa hospedeira para o vírus, fornecendo uma quantidade razoável de lesões locais para extração do vírus. Entretanto, diversas tentativas de purificação foram feitas e em nenhuma delas se obteve sucesso. Não foi possível visualizar partículas ao microscópio eletrônico de transmissão e tão pouco se obtiveram 
frações infectivas. A grande dificuldade foi com relação, principalmente, com a baixa estabilidade do vírus nos diversos tampões utilizados. Tentativas de purificação de folhas de $S$. vioaefolium coletadas diretamente no campo também não tiveram sucesso.

\subsection{Seqüenciamento de fragmentos do genoma viral}

\subsubsection{Isolamento de RNA dupla fita (dsRNA)}

Em virtude da dificuldade de purificação do SvRVS, o que facilitaria a extração do RNA viral, bem como o seqüenciamento, foi utilizada alternativamente a extração da fita dupla de RNA (dsRNA), o que possibilitou a obtenção de algumas informações sobre o genoma deste vírus. A Figura 11 mostra as bandas formadas na extração.

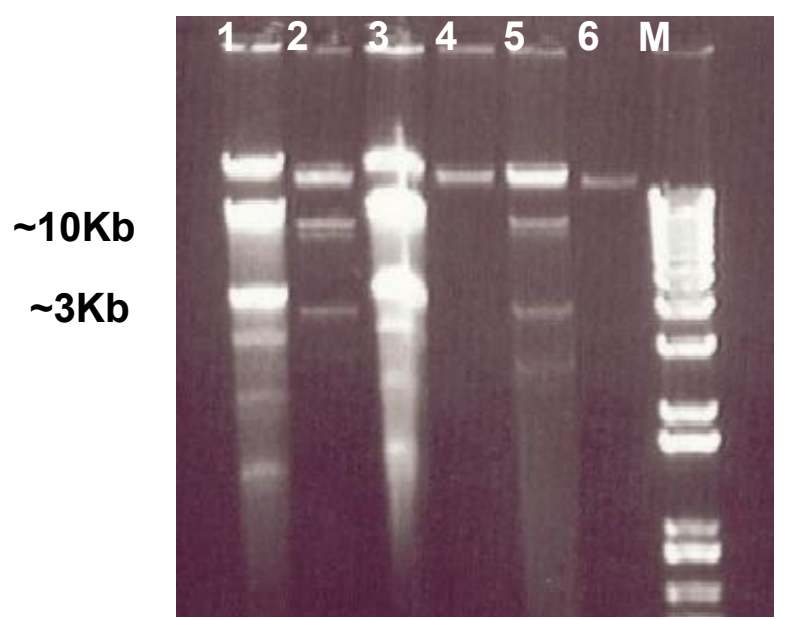

Figura 11 - Fotografia de gel de agarose 1\% para visualização das extrações de dsRNA. A) 1 a 3 - datura infectada com SvRSV, 4 - datura sadia, 5 - Solanum violaefolium infectada com SvRSV, 6 - S. violaefolium sadia, M - marcador $1 \mathrm{~kb}$ ladder (Invitrogen)

O dsRNA foi obtido somente a partir de plantas de S. violaefolium e $D$. stramonium sintomáticas para o SvRSV, ou seja, de tecidos infectados. O padrão de bandas observado para este vírus foi uma banda forte de 
aproximadamente $10 \mathrm{~Kb}$ e outra de $3 \mathrm{~Kb}$, tanto em datura quanto em solano. Em plantas sadias não foi observado a presença de dsRNA. Em todas as amostras foi observada uma banda acima do marcador $1 \mathrm{kbp}$ ladder (Invitrogen), provavelmente correspondente a contaminação por DNA vegetal. Esses valores também foram observados por Locali et al. (2004).

\subsubsection{Seqüenciamento e comparação com outros vírus no Genbank}

A partir da biblioteca de cDNA, obtiveram-se 6 clones, cujas seqüências formaram 3 "contigs" de 252, 325 , 600 pb que codificam para uma provável proteína da replicase e um de 535 pb que codifica para uma provável proteína de movimento (dados não mostrados).

As seqüências apresentam similiaridade com seqüências que codificam as proteínas replicase e de movimento de vírus membros dos gêneros Furovirus, Tobamovirus e da família Bromoviridae, á semelhança do que ocorreu com CiLV-C (Locali et al., 2003)

Em função da semelhança morfológica das partículas do SvRSV com outros vírus como CiLV, OFV, CoRSV, LigRSV, possuírem como vetor ácaros do gênero Brevipalpus, e apresentarem efeitos citopáticos semelhantes ao que ocorrem na família Rhabdoviridae e somado a isto, o fato de pequena seqüência do OFV ter mostrado similaridade com vírus desta família, acreditava-se que as seqüências obtidas tivessem homologia com algum vírus deste grupo, entretanto isto não foi observado.

As seqüências obtidas do SvRSV foram comparadas no GenBank com outras seqüências lá depositada, inclusive as da leprose dos citros. Assim como a seqüência do CiLV depositada no GenBank, os "contigs" do SvRSV é muito pequeno e isto não permite afirmar com certeza que não há similaridade entre estes dois vírus. Mas é importante mencionar que ambos tiveram similaridade com proteínas virais de Furovirus, Tobamovirus e Bromoviridae. $\mathrm{O}$ fato de se poder extrair dsRNA de SvRSV e de CiLV-C seria um indicativo de que seriam 
distintos de rhabdovirus, dos quais não há registro de obtenção de deRNA. A análise do genoma do CiLV-C que foi completamente seqüenciado vem reforçar esta idéia pois não é senso negativo, além de ser bipartido.

\subsubsection{Hibridizações}

Após a análise das seqüências no banco de dados, os clones do SvRSV que apresentaram seqüências altamente similares a seqüências de vírus de plantas foram marcados por quimioluminescência e utilizados como sondas para hibridização "Dot Blot" bem como controle para mesma. As amostras testes para hibridização foram espotadas na membrana de acordo com a figura 12.

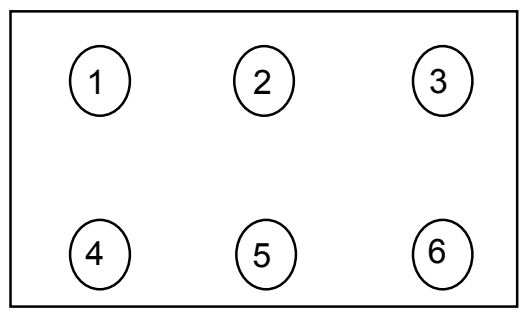

Figura 12 - Distribuiçao das amostras testes em membrana de nylon para hibridização. 1 - dsRNA de D. stramonium SvRSV (+); 2 - dsRNA de $D$. stramonium (-); 3 - ssRNA laranjeira CiLV (+); 4 - ssRNA de D. stramonium SvRSV (+); 5 - ssRNA de D. stramonium (-); 6 DNA do clone marcado (controle + )

Das regiões do genoma, os clones marcados foram utilizados para hibridização "dot blot". Os resultados da hibridização podem ser visto na Figura 13 e estão sumarizados na Tabela 5.

A sonda obtida a partir do clone 01A09 (região da replicase - rep) não hibridizou com qualquer uma das amostras espotadas na membrana, nem ao menos com o próprio DNA controle (Figura 13A), o que indica que a marcação desta sonda não fora eficiente. 


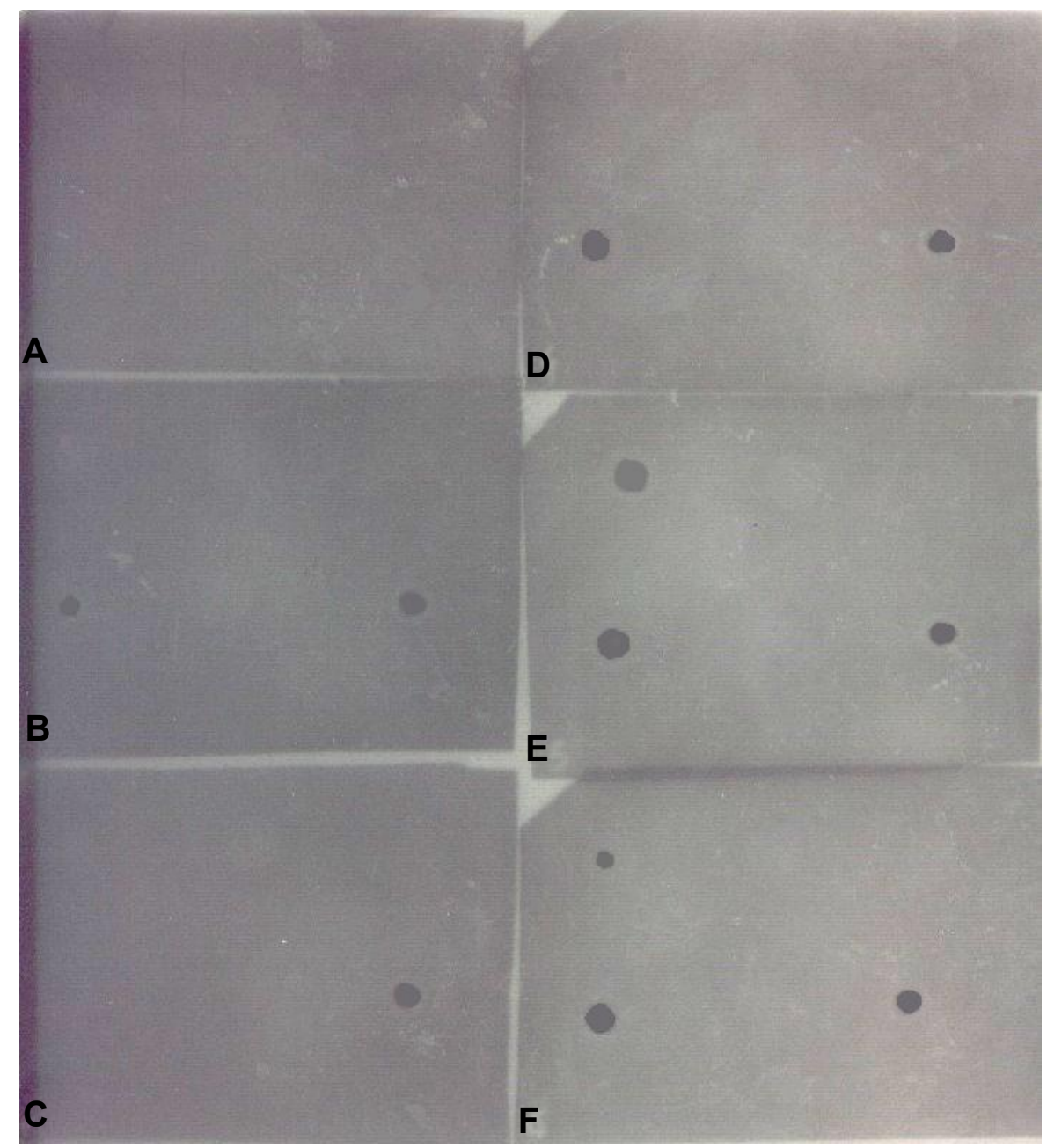

Figura 13 - Autoradiograma da hibridização com as sondas. Cada membrana contém dsRNA de D. stramonium com SvRSV e sadia, RNA total de D. stramonium com SvRSV e sadia, RNA total de laranja com CiLV e as sondas A - 01A09 (rep); B - 01E04 (rep); C - 01E12 (rep); D $02 F 07$ (mp); E - 03 A04 (mp); F - $03 \mathrm{G} 02$ (mp)

A sonda obtida a partir do clone 01E12 (região da replicase) hibridizou apenas com o DNA do controle positivo, o que sugere que este clone não representa parte genômica do vírus nem mesmo da planta hospedeira e sim um contaminante. 
As sondas obtidas a partir dos clones $01 \mathrm{E} 04$ (região da replicase), 02F07 (região da proteína de movimento - mp), 03A04 (região da proteína de movimento) e 03G02 (região da proteína de movimento), representam os clones que hibridizaram com o RNA total extraído de plantas de datura sintomáticas para o SvRSV (Figura13B e 13D) bem como o dsRNA de datura sintomática para o SvRSV (Figura 13E e 13F) indicando que estes clones apresentam homologia ao material genômico do vírus, uma vez que hibridizaram somente com amostras de plantas infectadas. Ausência de reação com o dsRNA dos clones 01E04 e 02F07 provavelmente ocorreu em função da baixa concentração desses dsRNA nas amostras. Em nenhuma das membranas foi observada reação de hibridização com o controle negativo (planta sadia), indicando que os clones obtidos não são provenientes do genoma da planta. Nenhuma das sondas obtidas a partir de clones do SvRSV hibridizaram com RNA total de plantas de citros sintomáticas para o CiLV, indicando aparentemente não haver homologia entre estes segmentos genomicos identificados do SvRSV com o CiLV.

Tabela 5. Resultado da hibridização por "dot blot" das amostras de dsRNA, ssRNA de Datura stramonium, ssRNA de Citros com leprose e os clones com homologia a putativa proteína de movimento e replicase

\begin{tabular}{|c|c|c|c|c|c|c|}
\hline \multirow[b]{2}{*}{ Sonda } & \multicolumn{2}{|c|}{ dsRNA } & \multicolumn{3}{|c|}{ ssRNA } & DNA \\
\hline & $\begin{array}{l}\text { Datura } \\
\text { SvRSV }\end{array}$ & $\begin{array}{c}\text { Datura } \\
\text { sadia }\end{array}$ & $\begin{array}{l}\text { Datura } \\
\text { SvRSV }\end{array}$ & $\begin{array}{c}\text { Datura } \\
\text { sadia }\end{array}$ & $\begin{array}{c}\text { Citros } \\
\text { CiLV-C }\end{array}$ & \\
\hline 01A09 & - & - & - & - & - & - \\
\hline 01E04 & - & - & + & - & - & + \\
\hline 01E12 & - & - & - & - & - & + \\
\hline 02F07 & - & - & + & - & - & + \\
\hline $03 \mathrm{~A} 04$ & + & - & + & - & - & + \\
\hline 03G02 & + & - & + & - & - & + \\
\hline
\end{tabular}


4.6.4 Síntese de iniciadores (primers) e RT-PCR para detecção

A amplificação de amostras de datura e solano-violeta infectadas com SvRSV resultou em fragmentos de diversos tamanhos sendo o maior deles de aproximadamente 600 pb, conforme esperado (Figura 14). O par de "primers" F1 e R2 mostrou-se o mais específico entre as quatro combinações testadas. Utilizando-se esses primers, foi possível detectar a presença do vírus através da amplificação de banda única apenas em amostras de solano-violeta e datura infectadas com SvRSV e não com amostras sadias. Os demais pares de "primers" reagiram inespecificamente com as amostras sadias testadas (Figura 14).

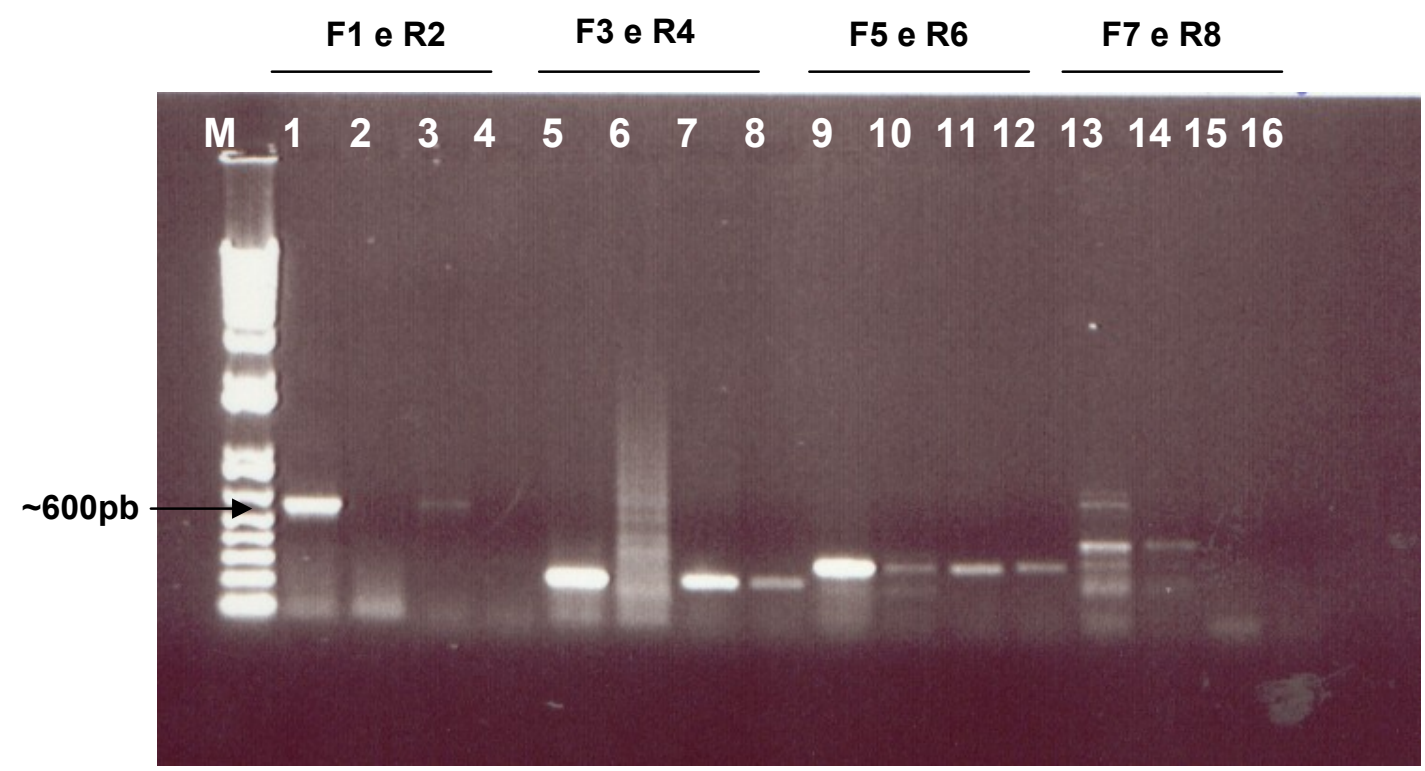

Figura 14 - Gel de agarose 1\%. M - marcador molecular Ladder $1 \mathrm{~Kb}$ plus (Invitrogen); 1, 5, 9, 13 - RNA total de S. violaefolium com SvRSV; 2, 6, 10, 14 - RNA total de S. violaefolium sadia; 3, 7, 11, 15 - RNA total de $D$. stramonium com SvRSV; 4, 8, 12, 16 - RNA total de $D$. stramonium sadia. 1 a 4 - primers F1 e R2; 5 a 8 - primers F3 e $\mathrm{R} 4 ; 9$ a 12 - primers F5 e R6; 13 a 16 - primers F7 e R8 
Os pares de "primers" F3, R4 e F5, R6 que foram desenhados para o gene da putativa replicase, assim como o par F7, R8 que foram desenhados para o gene da putativa proteína de movimento, apesar de ter reagido inespecificamente com amostras de datura e solano sadias, devem ainda ser alvos de estudos para testes de diagnose e continuação do sequenciamento completo do SvRSV.

Como pode ser observado na figura 14, o par de primers F1 e R2 se mostrou mais especifico do que os demais sendo que após sua otimização, as amplificações de material infectado com SvRSV se mostraram bastante específica (Figura 15).

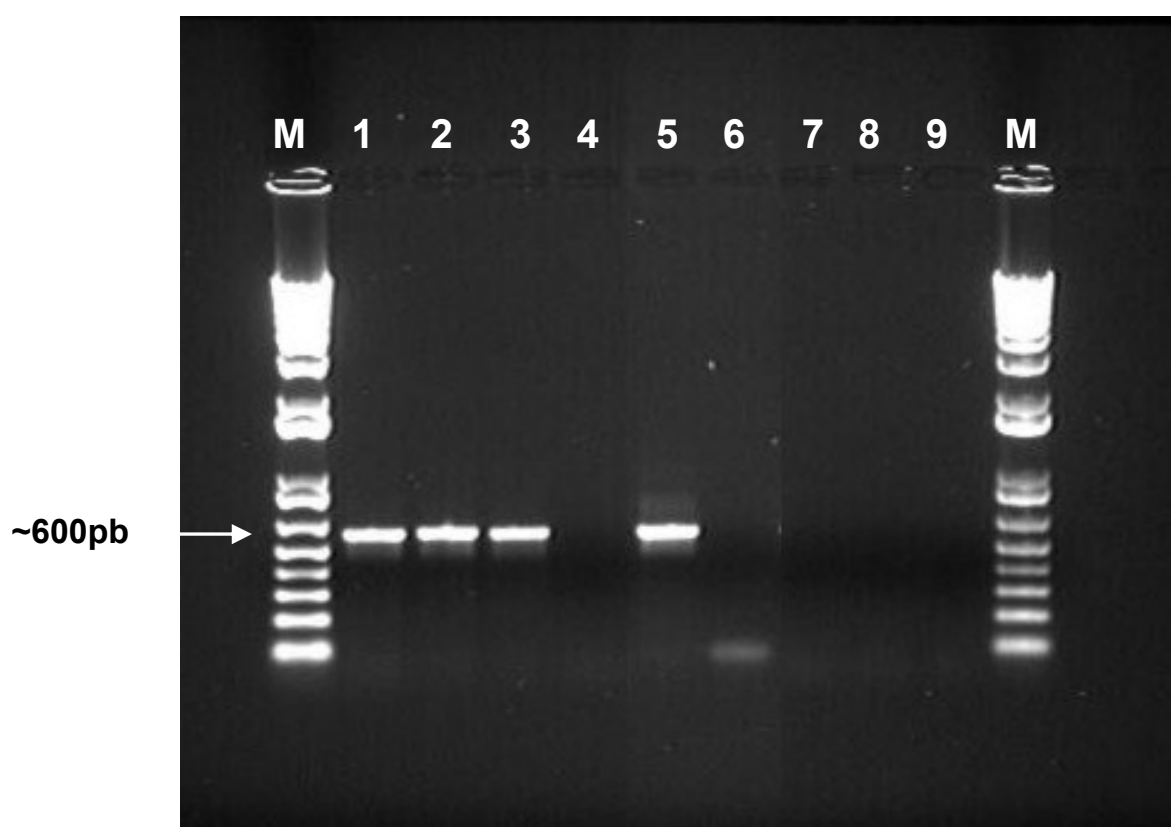

Figura 15 - Gel de agarose $1 \%$ do produto de PCR dos primers F1 E R2. M marcador molecular Ladder $1 \mathrm{~Kb}$ plus (Invitrogen); 1 a 3 - RNA total de solano infectada com SvRSV; 4 - RNA total de solano sadia; 5 dsRNA de solano com SvRSV; 6 - dsRNA de solano sadia; 7 e 8 cDNA de citros com CiLV-C; 9 - cDNA de citros sadio 
Os "primers" F1 e R2 amplificaram, através de RT-PCR, bandas de amostras provenientes de sálvia-branca (infectada com a mancha clorótica de Clerodendron) ligustro (infectada com a mancha verde de Ligustrum), e solanovioleta (infectada com SvRSV)(dados não mostrados).

Amostras de solano-violeta infectada com a mancha verde de ligustro também amplificou com os "primers", entretanto o controle sadio apresentou uma fraca banda. Não houve reação com as amostras de dama-da-noite infectada com o vírus da mancha clorótica de Clerodendron, orquídeas infectadas com OFV e citros infectada com CiLV. Não foi possível avaliar a amplificação nas amostras de kenaf, pois não se obteve um dsRNA de boa qualidade em função das características de viscosidade comum às espécies de Malvaceae.

Ainda há a necessidade de otimização destes ensaios para confirmar se os "primers" desenhados para a região genômica do SvRSV que amplificam a putativa replicase, conseguem amplificar outros vírus transmitidos por Brevipalpus e verificar se não houve apenas uma reação inespecífica. 


\section{CONCLUSÕES}

O conjunto de informações disponíveis indica que o vírus encontrado em S. violaefolium, causando lesões localizadas anelares, é transmitido pelo ácaro $B$. phoenicis e possivelmente por $B$. obovatus, bem como mecanicamente não só para $S$. violaefolium, mas também para várias outras hospedeiras, sempre resultando em infecção localizada. O vírus foi designado de mancha anular do S. violaefolium (S. violaefolium ringspot vírus- SvRSV).

Suas propriedades físicas in vitro indicam ser relativamente lábil, o que resultou no insucesso nas tentativas de purificação. A morfologia de suas partículas e as alterações citopáticas induzidas nas células infetadas são características dos vírus transmitidos por ácaros Brevipalpus, do tipo citoplasmático, induzindo o aparecimento de um viroplasma citoplasmático. Sua morfogênese parece ser por "brotação" a partir de material do viroplasma.

Pode-se obter 2 fragmentos do genoma deste vírus a partir do dsRNA extraído de lesões. Pela análise de suas seqüências concluiu-se que teriam homologia com proteína de movimento e de replicase de alguns vírus de planta como do gênero Furovirus, Tobamovirus e da família Bromoviridae, de maneira similar ao observado com o CiLV-C. Contudo não houve coincidências nestas seqüências entre SVRSV e CiLV-C.

Foi possível preparar "primers" que amplificaram especificamente fragmentos de DNA a partir de dsRNA ou ssRNA extraído de lesões causadas por SvRSV, por RT-PCR e também sondas moleculares que hibridizavam com os mesmos. Estes "primers" e as sondas não reconheceram CiLV-C, 
confirmando a falta de homologia entre as seqüências conhecidas do SvRSV com as do CiLV-C.

O CiLV-C que tem o seu genoma completamente seqüenciado seria definitivamante distinto dos rhabdovirus devendo representar um novo grupo de vírus. SvRSV pelas características gerais pertenceria a este grupo, mas os dados existentes sugerem que seriam vírus distintos. $O$ fato de as partículas do SvRSV serem ligeiramente mais delgadas e eventualmente, mais longas, talvez indique ser ele um subgrupo dentro dos vírus transmitidos por Brevipalpus, do tipo citoplasmático.

Vale mencionar que apesar de várias tentativas SvRSV não logrou infetar plantas cítricas, mas CiLV-C causou lesões cloróticas em S. violaefolium em ensaios de transmissão por ácaros, e o efeito citopático observado foi o mesmo observado em lesões lepróticas de citros. (J.C.V. Rodrigues, comunicação pessoal) 


\section{REFERÊNCIAS BIBLIOGRÁFICAS}

ALBUQUERQUE, F.A.; OLIVEIRA, C.A.L.; BARRETO, M. Comportamento do ácaro Brevipalpus phoenicis (Geijskes). In: OLIVEIRA, A.A.L.; DONADIO, L.C. (Ed.). Leprose dos citros. Jaboticabal: FUNEP, 1995. p77-90.

ALVES, E.B. Manejo da resistência do ácaro da leprose Brevipalpus phoenicis (Geijskes, 1939)(Acari: Tenuipalpidae) ao acaricida dicofol. Piracicaba, 1999. 91p. Dissertação (Mestrado) - Escola Superior de Agricultura "Luiz de Queiroz", Universidade de São Paulo.

ANTONIOLI, R.; LOCALI, E.C.; KITAJIMA, E.W.; MACHADO, M.A.; FREITASASTÚA, J. Detecção de vírus transmitidos por ácaros do gênero Brevipalpus através de dsRNA. Summa Phytopathologica, v.29, p.75, 2003

ÁVILA, A.C.; DE HANN, P.; KORMELINK, R.; RESENDE, R.O.; GOLDBACH, R.W.; PETERS, D. Classification of tospovirus based on the phylogeny of nucleocapsid gene sequences. Journal of General Virology, v.74, p.153159, 1993.

ÁVILA, A.C.; RUNGUENOT, C.; RESENDE, R.O.; KITAJIMA, E.W.; GOLDBACH, R.W.; PETERS, D. Serological differentiation of 20 isolates of tomato spotted wilt virus. Journal of General Virology, v.71, p.2801-2807, 1990.

BAKER, E. W. The genus Brevipalpus (Acari: Pseudoleptidae). American Midland Naturalist, v.42, p.350-402, 1949. 
BARRETO, M.; PAVAN, A. Relação verrugose X leprose. In: OLIVEIRA, A.A.L.; DONADIO, L.C. (Ed). Leprose dos citros. Jaboticabal: FUNEP. 1995. p6976.

BEGTRUP, J. Structure of a bacilliform virus in Dendrobium as revealed by negative staining. Phytopathologische Zeittschrift, v.75, p.268-273. 1972.

BITANCOURT, A.A. A mancha anular, uma nova doença do cafeeiro. $\mathbf{0}$ Biológico, v.4, p.404-405, 1938.

BITANCOURT, A.A.; GRILLO, N.V.S. A clorose zonada. Arquivos do Instituto Biológico, v.5, p.247-250, 1934.

BLANCHFIELD, A.L.; MACKENZIE, A.M.; GIBBS, A.; KONDO, H.; TAMADA, T.; WILSON, C.R. Identification of Orchid fleck virus by reverse transcriptasepolimerase chain reaction and analysis of isolate relationships. Journal of Phytopathology, v.149, p.713-718, 2001.

BOARI, A.J.; FIGUEIRA, A.R.; NEDER, D.G.; INFIESTA, L.R.; NOGUEIRA, N.L.; ROSSI, M.L.; KITAJIMA, E.W. Efeito da temperatura na infecção sistêmica de Chenopodium quinoa pelo Coffee ringspot virus (CoRSV). Fitopatologia Brasileira, v.28, p.246, 2003. IApresentado ao 35. Congresso Brasileiro de Fitopatologia, Uberlândia - Resumo/.

BOARI, A.J.; FREITAS-ASTÚA, J.; FERREIRA, P.T.O..; NEDER, D.G.; NOGUEIRA, N.L.; ROSSI, M.L.; KITAJIMA, E.W. Purification and serology of the coffea ringspot virus. Summa Phytopathologica, v.30, p.453-458, 2004.

BRAY, D.F. A comparison of HMDS, Peldri II and critical point drying methods for SEM of biological specimens. Microscopy Research and Technique, v.26, p.489-495, 1993.

CHAGAS, C.M. A associação do ácaro Brevipalpus phoenicis (Geijskes) à mancha anular do cafeeiro. O Biológico, v.39, p.229-232, 1978a. 
CHAGAS, C.M. Mancha anular do cafeeiro: Transmissibilidade, Identificação do vetor e aspectos anátomo-patológicos da espécie Coffea arabica L. afetada pela moléstia. São Paulo, 1978b. 132p. Tese (Doutorado) - Instituto de Biociências, Universidade de São Paulo.

CHAGAS, C.M. Morphology and intracellular behavior of coffee ringspot virus (CRV) in tissues of coffee (Coffea arabica L.). Phytopathologische Zeittschrift, v.99, p.301-309, 1980.

CHAGAS, C.M.; JULY, J.R.; ALBA, A.P.C. Mechanical transmission and structural features of coffea ringspot virus (CRV). Phytopathologische Zeittschrift, v.192, p.200-106, 1981.

CHAGAS, C.M.; ROSSSETTI, V.; CHIAVEGATO, L.G. Effectiveness of the different life cycle stages of Brevipalpus phoenicis Geijskes in leprosis transmission. In: CONFERENCE OF THE INTERNATIONAL ORGANIZATION OF CITRUS VIROLOGISTS, 9., Puerto Iguazu, 1984. Proceedings. Riverside: IOCV, 1984. p.211-214.

CHAGAS, C.M.; COLARICCIO, A.; MIYAI, T.; GALLETI, S.R. Microscopia eletrônica da pinta verde do maracuja. Summa Phytopathologica, v.26, p.31, 2000.

CHIAVEGATO, L.G. Biologia do ácaro Brevipalpus phoenics em citros. Pesquisa Agropecuária Brasileira, v.21, p.813-816, 1986.

CHIAVEGATO, L.G.; MISCHAN, M.M. Comportamento do ácaro Brevipalpus phoenicis (Geijskes, 1939)(Acari:Tenuipalpidae). Científica, v.15, p.17-22, 1987.

CHILDERS, C.C.; RODRIGUES, J.C.V.; WELBOURN, W.C. Host plants of Brevipalpus californicus, B. obovatus and B. phoenicis (Acari: Tenuipalpidae) and their potential involvement in the spread of viral disease vectored by these mites. Experimental and Applied Acarology, v.30, p.29-105, 2003. 
CHOI, Y.G.; RANDLES, J. Microgranular celulose improved dsRNA recovery from plant nucleic acid Extracts. BioTecnhniques, v.23, p.610-611, 1997.

CHU, F.-H.; YEH, S.-D. Comparison of ambisense M RNA of Watermelon Silver Mottle virus with other Tospovirus. Phytopathology, v.88, p.351-358, 1998.

COLARICCIO, A.; LOVISOLO, O.; BOCCARDO, G.; CHAGAS, C.M.; D’AQUILO, M.; ROSSETTI, V. Preliminary purification and double stranded RNA analysis of citrus leprosis virus. In: CONFERENCE OF THE INTERNATIONAL ORGANIZATION OF CITRUS VIROLOGISTS, 14., Campinas, 2000. Proceedings. Riverside: IOCV, 2000. p.159-163.

COLARICCIO, A.; LOVISOLO, O.; CHAGAS, C.M.; GALLETTI, S.R.; ROSSETTI, V.; KITAJIMA, E.W. Mechanical transmission and ultrastructural aspects of citrus leprosis virus. Fitopatologia Brasileira, v.20, p.208-213. 1995.

DERRICK, K.S.; BRLANSKY, R.H.; LEE, R.F.; TIMMER, L.W.; NGUYEN, T.K. Two components associated with citrus ringspot virus. In: CONFERENCE OF THE INTERNATIONAL ORGANIZATION OF CITRUS VIROLOGISTS, 10., Valência, 1988. Proceedings. Riverside: IOCV, 1988. p.340-342.

DODDS, J.A. dsRNA in diagnosis. In: MATTHEWS, R.F.W. (Ed.). Diagnosis of plant virus diseases. Boca Raton: CRC Press. 1993. p.273-294.

DODDS, J.A.; MORRIS, T.J.; JORDAN, R.L. Plant viral double-stranded RNA. Annual Review of Phytopathology, v.22, p.151-168, 1984.

DOI, Y.; CHANG, M.U.; YORA, K. Orchid fleck virus. CMI/AAB Description of Plant Viruses, n.183, 1977. 4p.

DOMINGUEZ, F.S.; BANDEL, A.; CHILDERS, C.; KITAJIMA, E.W. Leprose dos citros no Panamá. Summa Phytopathologica, v.26, p.132, 2000.

DUVEL, D.; PETERS, K.R. Virusahnlicke partikel in Dendrobium antennatum. Gartenwelt, v. 3, p.52-54, 1971. 
FAWCETT, H.S. Citrus diseases and their control. New York: McGraw Hill, 1936. 582p.

FERREIRA, P.T.O.; FREITAS-ASTÚA, J.; RODRIGUES, J.C.V.; KITAJIMA, E.W. Dados preliminares de transmissão mecânica e por ácaros de alguns vírus transmitidos por Brevipalpus. Fitopatologia Brasileira, v.28, p.250, 2003. /Apresentado ao 35. Congresso Brasileiro de Fitopatologia, Uberlândia, 2003 - Resumo/.

FLECHTMANN, C.H.W. Ácaros de importância agrícola. São Paulo: Nobel, 1977. 150p.

FRANCKI, R.I.B.; KITAJIMA, E.W.; PETER, D. Rhabdoviruses. In: KURSTAK, E. (Ed.). Handbook of plant virus infections and comparative diagnosis. Amsterdam: Elsevier/North-Holland Biomedical Press, 1981. p.455-491.

FREITAS-ASTÚA, J.; REZENDE, J.A.M.; KITAJIMA, E.W. Incidence of orchid viruses in the state of São Paulo. Fitopatologia Brasileira, v.24, p.125-130, 1999.

FREITAS-ASTÚA, J.; FERREIRA, P.T.O.; REZENDE, J.A.M.; KITAJIMA, E.W. Partículas baciliformes associadas a manchas verdes e cloróticas em folha de dama-da-noite (Cestrum nocturnum - Solanaceae). Fitopatologia Brasileira, v.27, p.210, 2002. IApresentado ao 34. Congresso Brasileiro de Fitopatologia, Recife, 2002 - Resumo/.

FREITAS-ASTÚA, J.; RODRIGUES, V.; LOCALI, E.C.; ASTÚA-MONGE, G.; FERREIRA, P.T.O.; KITAJIMA, E.W.; MACHADO, M.A. Transmissão do vírus da mancha anular da dama-da-noite por ácaros Brevipalpus spp. Summa Phytopathologica, v.30, p.80, 2004.

FREZZI, M.S. La lepra explosiva del naranjo - investigaciones realizadas por el laboratorio de patologia de Bella Vista (Corrientes). Boletin Frutas y Hortalizas, n.5, 1940. 16p. 
GIBBS, A.; MACKENZIE, A. A primer pair for amplifying part of the genome of all potyvirids by RT-PCR. Journal of Virology Methods, v.63, p.9-16, 1997.

GLÓRIA, B.A.; CAPOTE-ALBERNAZ, M.C.; AMORIM, L. Structural characteristics of buds of sugarcane cultivars with different levels for resistance to smut. Journal of Plant Diseases and Protection, v.102, p.502-508, 1995.

GONZÁLES, R.H. Revision of the Brevipalpus phoenicis "complex" with descritions of new species from chile and Thailand (Acarina: Tenuipalpidae). Acarologia, v.17, p.81-91, 1975.

GOWANLOCK, D.H.; DIETZGEN, R.G. Small rhabdovirus-like particles in violet (Viola spp.). Australasian Plant Pathology, v.24, p.215-216, 1995.

GUERRA-MORENO, A.S.; MANJUNAH, K.L.; BRLANSKY, R.H.; LEE, R.F. A multi-partite RNAvirus associated with leprosis disease of citrus. In: CONFERENCE OF THE INTERNATIONAL ORGANIZATION OF CITRUS VIROLOGISTS, 15., Monterey, 2004. Proceedings. Riverside: IOCV, 2000. p.96.

GUIRADO, N.; SILVÉRIO, J.L. Leprose e declínio: problemas sérios da citricultura paulista. Laranja, v.13, p.541-552, 1992.

HARAMOTO, F.H. Biology and control of Brevipalpus phoenicis (Geijskes, 1939)(Acarina: Tenuipalpidae). Hawaii Agricultural Experimental Station Technical Bulletin, n.68, p.1-63,1969.

HARRIS, K.F.; SMITH, O.P.; DUFFUS, J.E. (Ed.). Virus-insect-plant interactions. San Diego: Academic Press, 2001. 376p.

HELLE, W.; BOLLAND, H.R.; HEITMANS, W.R.B. Chromosomes and types of parthenogenesis in the false spider mites (Acari: Tenuipalpidae). Genetica, v.54, p.545-550, 1980. 
HSU, H.T.; BLACK, L.M. Polyethylene glycol for purification of potato yellow dwarf virus. Phytopathology, v.63, p.692-696, 1973.

HULL, R. Matthews' plant virology. 4.ed. San Diego: Academic Press, 2002. $1001 p$.

INTERNATIONAL COMMITTEE ON TAXONOMY OF VIRUSES. Index to virus classification and nomenclatures taxonomic lists and catalogue of Viruses. ICTVdb - The Universal Virus Database: http://www.ncbi.nlm.nih.gov/ICTVdb/lctv/fr-index.htm, 2002. (17/nov./2004).

JACKSON, A.O.; WAGNER, J.D.O. Procedures for plant rhabdovirus purification, polyribosome isolation, and replicase extraction. In: FOSTER, G.D.; TAYLOR, S.C. (Ed.). Plant virology protocols: from virus isolation to transgenic resistance. Totowa: Humana Press, 1998. p.77-97.

JEPPSON, L.R.; KEIFER, H.H.; BAKER, E.W. Mites injurious to economic plants. Berkeley: University of California, 1975. 614p.

KATO, K.; HANADA, K.; DAMEYA-IWAKI, M. Transmission mode, host range and electron microscopy of a pathogen causing a new disease of melon (Cucumis melo) in Japan. Annual of Phytopathology Society of Japan, v.65, p.624-627, 1999.

KITAJIMA, E.W. Curso introdutório de microscopia eletrônica de transmissão, Piracicaba: ESALQ, Núcleo de Apoio à Pesquisa/Microscopia Eletrônica Aplicada a Pesquisa Agropecuária, 1998. 43p.

KITAJIMA, E.W.; COSTA, A.S. Partículas baciliformes associadas à mancha anular do cafeeiro. Ciência e Cultura, v.24, p.542-545, 1972.

KITAJIMA, E.W.; LEITE, B. Curso introdutório de microscopia eletrônica de varredura. 2.ed. Piracicaba: ESALQ, Núcleo de Apoio à Pesquisa/Microscopia Eletrônica Aplicada a Pesquisa Agropecuária. 1999. $46 p$. 
KITAJIMA, E.W.; MORAES, G.J. Manchas cloróticas em Clerodendron $x$ speciosum e mancha anular em Solanum violaefolium associados a efeitos citopáticos similares aos dos vírus transmitidos pelo ácaro Brevipalpus. Summa Phytopathologica, v.26, p.133-134, 2000.

KITAJIMA, E.W.; NOME, C. Microscopia eletrônica de vírus de plantas. In: DOCAMPO, D. M.; LENARDÓN, S. L. (Ed.). Métodos para detectar patógenos sistemicos. Córdoba: IFFYVE/INTA, 1999. p.59-87.

KITAJIMA, E.W.; RODRIGUES, J.C.V. Mancha verde e mancha clorótica de Hibiscus são causadas por tipos diferentes de vírus transmitidos por Brevipalpus. Summa Phytopathologica, v.27, p.105, 2001.

KITAJIMA, E.W.; BLUMENSCHEIN, A.; COSTA, A.S. Rodlike particles associated with ringspot symptoms in several orchid species in Brazil. Phytopathologische Zeittschrift, v.81, p280-284, 1974a.

KITAJIMA, E.W.; CHAGAS, C.M.; RODRIGUES, J.C.V. Brevipalpus-transmitted plant virus and virus-like diseases: cytopathology and some recent cases. Experimental and Applied Acarology, v.30, p.135-160, 2003.

KITAJIMA, E.W.; MULLER, G.W.; COSTA, A.S.; YUKI, V.A. Short rodlike particles associated with citrus leprosis. Virology, v.50, p.254-258, 1972.

KITAJIMA, E.W.; KUBO, K.S.; GOMES, R.T.; FERREIRA, P.T.O. Manchas cloróticas em solano-violeta, transmissível pelo ácaro Brevipalpus associado a um vírus do tipo nuclear. Fitopatologia Brasileira, v.29, p.65, 2004. IApresentado ao 36. Congresso Brasileiro de Fitopatologia, Gramado, 2004 Resumo/.

KITAJIMA, E.W.; NOVAES, Q.S.; REZENDE, J.A.M.; MORAES, G.J. Short, rhabdovirus-like particles and a caulimovirus in Hibiscus rosa-sinensis with green spot. In: SCANDEM, 51., Bergen, 1999. Proceedings. Alnarp: Swedish University of Agricultural Sciences, 1999. p. 63-64. 
KITAJIMA, E.W.; ROSILLO, M.A.; PORTILLO, M.M.; MULLER, G.W.; COSTA, A.S. Microscopia eletrônica de tecidos foliares de laranjeiras infetados pela lepra explosiva da Argentina. Fitopatologia, v.9, p.55-56, 1974b.

KITAJIMA, E.W.; REZENDE, J.A.M.; RODRIGUES, J.C.V.; CHIAVEGATO, L.G.; PIZA JUNIOR,C.T.; MOROZINI, W.S. Green spot of passion fruit, a possible viral disease associated with infestation by the mite Brevipalpus phoenicis. Fitopatologia Brasileira, v.22, p.555-559, 1997.

KITAJIMA, E.W.; REZENDE, J.A.M.; NOVAES, Q.S.; PEDRAZZOLLI, D.; RABELO, L.C.; GIORIA, R. Vírus da mancha anular de Solanum violaefolium: Transmissão mecânica e pelo ácaro Brevipalpus phoenicis. Summa Phytopathologica, v.27, p.105, 2001a.

KITAJIMA, E.W.; KONDO, H.; MACKENZIE, A.; REZENDE, J.A.M.; GIORIA, R.; GIBBS, A.; TAMADA, T. Comparative cytopathology and immunocytochemistry of Japanese, Australian and Brazilian isolates of orchid fleck virus. Journal of General Pathology, v.67, p.231-237, 2001b.

KNORR, L.C. Studes on the etiology of leprosis in Citrus. In: CONFERENCE OF THE INTERNATIONAL ORGANIZATION OF CITRUS VIROLOGISTS, 4., Rome, 1968. Proceedings. Gainesville: University of Florida Press, 1968. p.332-341

KNORR, L.C.; DENMARK, H.A. Injury to citrus by the mite Brevipalpus phoenicis. Journal of Economic Entomology, v.63, p.1996-1998, 1970.

KONDO, H.; MAEDA, T.; TAMADA, T.; SHIRAKO, Y. The genome structure of orchid fleck virus shows to be a unique bipartite genome virus that resembles rhabdovirus. In: INTERNATIONAL CONGRESS OF PLANT PATHOLOGY, 7., $\quad$ Edinburgh, $\quad$ 1998. http://www.bspp.org.uk/icpp98/1.11/81.html (23/fev./2003)

LAL, L. Biology of Brevipalpus phoenicis (Geijskes) (Acarina: Tenuipalpidae). Acarologia, v.20, p.97-101, 1978. 
LANE, L.C. A general method for detecting plant viruses. In: MARAMOROSCH, K. (Ed.). Plant diseases of viral, viroid, mycoplasma and uncertain etiology. New Delhi: Oxford \& IBH Publishing, 1992. p.1-17.

LESEMANN, D.; BEGTRUP, J. Elektronenmikroskopischer Nachweis eines bacilliform Viren in Phalaenopsis. Phytopathologische Zeittschrift, v.71, p.257-269, 1971.

LIMA, M.L.R.C.; COSTA LIMA N.V.; SOUZA, V.B.V. The causal agent of the Ligustrum ringspot disease. Phytopathology, v.81, p.1216, 1991.

LOCALI, E. C. Sequenciamento de regiões genômicas do vírus da leprose dos citros. Botucatu, 2002. 87p. Dissertação (Mestrado) - Instituto de Biociências de Botucatu, Universidade Estadual Paulista “Julio Mesquita Filho".

LOCALI, E.C.; FREITAS-ASTÚA, J.; KITAJIMA, E.W.; MACHADO, M.A. Confirmação da presença de dsRNA asssociado a Citrus leprosis virus (CiLV) e Orchid fleck virus (OFV). Summa Phytopathologica, v.29, p.76, $2003 a$.

LOCALI, E.C.; FREITAS-ASTÚA, J.; RODRIGUES, V.; MACHADO, M.A. Caracterização parcial do genoma de vírus transmitido por Brevipalpus phoenicis. Fitopatologia Brasileira, v.29, s.99, 2004./Apresentado ao 36. Congresso Brasileiro de Fitopatologia, Gramado, 2004 - Resumo/.

LOCALI, E.C.; FREITAS-ASTÚA, J.; SOUZA, A.A.; TAKITA, M.A.; ASTÚAMONGE, G.; ANTONIOLI, R.; KITAJIMA, E.W.; MACHADO, M.A. Diagnose da leprose dos citros através de RT-PCR. Summa Phytopathologica, v.29, p.75, 2003b.

LOCALI, E.C.; FREITAS-ASTÚA, J.; SOUZA, A.A.; TAKITA, M.A.; ASTUAMONGE, G.; ANTONIOLI, R.; KITAJIMA, E.W.; MACHADO, M.A. Development of a molecular tool for the diagnosis of leprosis, a major threat to citrus production in the Americas. Plant Disease, v.87, p.1317-1321, 2003c. 
LORENZI, H.; SOUZA, H.M. Plantas ornamentais no Brasil: arbustivas, herbáceas e trepadeiras. São Paulo: Ed. Plantarum, 1995. 720p.

LORENZI, H.; SOUZA, H.M. Plantas ornamentais no Brasil: arbustivas, herbáceas e trepadeiras. 3.ed. São Paulo: Ed. Plantarum, 2001. 1088p.

LOVISOLO, O.; COLARICCIO, A.; MASENGA, V. New experimental host further information on Citrus Leprosis Virus. In: CONFERENCE OF THE INTERNATIONAL ORGANIZATION OF CITRUS VIROLOGISTS, $14 .$, Campinas, 2000. Proceedings. Riverside: IOCV. 2000. p.164-173.

LOVISOLO, O.; COLARICCIO, A.; CHAGAS, C.M.; ROSSETTI, V; KITAJIMA, E.W.; HARAKAVA, R. Partial characterization of Citrus leprosis virus. In: CONFERENCE OF THE INTERNATIONAL ORGANIZATION OF CITRUS VIROLOGISTS, 13., Fuzhou, 1996. Proceedings. Riverside: IOCV. 1996. p.179-188.

MAEDA, T.; KONDO, H.; MISUHATA, K.; TAMADA, T. Evidence that orchid fleck virus is efficiently transmitted in a persistent manner by the mite Brevipalpus californicus. In: INTERNATIONAL CONGRESS OF PLANT PATHOLOGY, 7., Edinburgh, 1998. http://www.bspp.org.uk/icpp98/1.13/18.html (23/fev./2003).

MORAIS, F.H.R.; BELO, W.R.F.; QUEIRÓS, E.M.; CHAVES, N.P.; AMORIM, H.C.O.; KITAJIMA, E.W. Ocorrência do vírus da pinta verde em maracujá no Estado do Maranhão. Fitopatologia Brasileira, v.29, p.88, 2004. IApresentado ao 36. Congresso Brasileiro de Fitopatologia, Gramado, 2004 Resumo/.

MUSUMECCI, M.R.; ROSSETTI, V. Transmissão de sintomas de leprose dos citros pelo ácaro Brevipalpus phoenicis. Ciência e Cultura, v.15, p.228, 1963.

NAKANO, O.; SANCHES, G.A.; ISHIDA, A.K. Redução da infestação do ácaro da leprose Brevipalpus phoenicis (Geijskes) em citros através do controle da verrugose. Laranja, v.8, p.19-33, 1987. 
NEVES, E.M.; DRAGONE, D.S.; DAYOUB, M. Demanda por defensivos na citricultura: análise comparativa com outras culturas comerciais. Laranja, v.22, p.285-297, 2001.

NEVES, E.M.; RODRIGUES, L.; DRAGONE, D.S.; DAYOUB, M. Efeitos alocativos na citricultura: um comparativo entre os anos de crise e de euforia. Laranja, v.24, p.1-17, 2003.

OLIVEIRA, C.A.L. Flutuação populacional e medidas de controle do ácaro da leprose Brevipalpus phoenicis (Geijskes, 1939) em citros. Laranja, v.7, p.1$31,1986$.

OLIVEIRA, C.A.L.; DONADIO, L.C. (Ed.). Leprose dos citros. Jaboticabal: FUNEP, 1995. 219p.

OOMEN, P.A. Studies on population dynamics of the scarlet mite, Brevipalpus phoenicis, a pest of tea in Indonesia. Wageningen: Veenman \& Zonen, 1982. 88p.

PECCI, M.P.G. Detecção de dsRNA viral. In: DOCAMPO, D.M.; LENARDÓN, S.L. (Ed.). Métodos para detectar patógenos sistemicos. Cordoba: IFFYVE/INTA, 1999. p.41-49.

PETZOLD, H. Der elektronenmikroskopische Nachweis eines bacilliformen virus an blattflecken kranken Dendrobium. Phytopathologische Zeittschrift, v.70, p.43-52, 1971.

RODRIGUES, J.C.V. Relações virus-planta-vetor no patosistema da leprose dos citros. Piracicaba, 2000. 168p. Tese (Doutorado) - Centro de Energia Nuclear na Agricultura, Universidade de São Paulo.

RODRIGUES, J.C.V.; NOGUEIRA, N.L. Brevipalpus phoenicis (Acari: Tenuipalpidae) vector do possível vírus da mancha anular do Ligustrum lucidum. Fitopatologia Brasileira, v.22, p.341, 1997. 
RODRIGUES, J.C.V.; TARGON, M. L.N.; MACHADO, M.A. dsRNA associado a lesões de leprose dos citros. Fitopatologia Brasileira, v.25, p.447-448, 2000 .

RODRIGUES, J.C.V.; KITAJIMA, E.W.; CHILDERS, C.C.; CHAGAS, C.M.; MACHADO, M.A. Citrus leprosis virus vectored by Brevipalpus phoenicis (Acari: Tenuipalpidae) on citrus in Brazil. Experimental and Applied Acarology, v.30, p.161-197, 2003.

ROSS, A.F. Identification of plant viruses. In: CORBETT, M.K.; SISLER, H.D. (Ed.). Plant virology. Gainesville: University of Florida Press, 1964. p.68-92.

ROSSETTI, V.; SALIBE, A.A. Experiências sobre o controle da leprose em citrus. Arquivos do Instituto Biológico, v.26, p.119-130, 1959.

ROSSETTI, V.; NAKADAIRA, J.T.; CALZA, R.; BONFANTI, D.E.; MIRANDA, C.A.B. A propagação da clorose zonada dos citros por ácaros Brevipalpus phoenicis. O Biológico, v.31, p.113-116, 1965.

SALVA, R.A.; MASSARI, C.A. Situação do ácaro da leprose no estado de São Paulo - Levantamento Fundecitrus, agosto 1995. In: OLIVEIRA, C.A.L.; DONADIO, L.C. (Ed.). Leprose dos citros. Jaboticabal, FUNEP 1995. p.1316

SALVO FILHO, A. Nota sobre o tratamento fitossanitário em citros. Laranja, v.18, p.155-163, 1997.

SAMBROOK, J.; FRITSCH, E.F.; MANIATIS, T. Molecular cloning: a laboratory manual. 2.ed. New York: Cold Spring Harbor Laboratory Press, 1989. 1659p.

SMILEY, R.L.; GERSON, U. A review of the Tenuipalpidae (Prostigmata) and a new subfamily classification. ACAROLOGY, 9., Columbus, 1996. Proceedings. Columbus: Ohio Biological Survey, 1996. p.367-371. 
SMILEY, R.L.; FROST, W.E.; GERSON, U. A review of the Tenuipalpidae (Acari: Prostigmata) of Australia with descriptions of two new genera and four new species. International Journal of Acarology, v.21, p.33-45, 1996.

TAKATSU, A.; PEREIRA, A.F.; SILVA, J.R. Levantamento de doenças do maracujazeiro no Triângulo Mineiro. Fitopatologia Brasileira, v.25, p.332333, 2000.

TRINDADE, M.L.B. Caracterização biológica dos ácaros Brevipalpus obovatus Donnadieu, 1875, Brevipalpus californicus (Bank, 1904) e Brevipalpus phoenicis (Geijskes, 1939)(Acari: Tenuipalpidae) no Estado de São Paulo. Botucatu, 1990. 108p. Dissertação (Mestrado) - Faculdade de Ciências Agronômicas, Universidade Estadual Paulista "Julio Mesquita Filho".

TRINDADE, M.L.B.; CHIAVEGATO, L.G. Caracterização biológica dos ácaros Brevipalpus obovatus D., B. californicus B. e B. phoenicis G. (Acari: Tenuipalpidae). Anais da Sociedade Entomológica do Brasil, v.23, p.189195, 1994.

VALVERDE, R.A.; NAMETH, S.T.; JORDAN, R.L. Analysis of double-stranded RNA for plant virus diagnostic. Plant Disease, v.74, p.255-258, 1990.

VERGANI, A.R. Transmission y naturaleza de la "lepra explosiva" del naranjo. Buenos Aires: Instituto de Sanidad Vegetal. 1945. 11p. (Serie A5, n.3)

WEEKS, A.; MAREK, F.; BREEUWE, J.A.J. A mite species that consists entirely of haploid females. Science, v.292, p.2479-2482, 2001.

WELBOURN, W.C.; OCHOA, R.; KANE, E.C.; ERBE, E.F. Morphological observations on Brevipalpus phoenicis (Acari: Tenuipalpidae) including comparisons with $B$. californicus and $B$. obovatus. Experimental and Applied Acarology, v.30, p.107-133, 2003. 
WUNNER, W.H.; CALISHER, C.H.; DIETZGEN, R.G.; JACKSON, A.O.; KITAJIMA, E.W.; LAFON, M.; LEONG, J.C.; NICHOL, S.; PETERS, D.; SMITH, J.S.; WALKER, P.J. Rhabdoviruses. Archives of Virology, supplement 10, p.275-288, 1995. 